Tesis para optar al grado de Doctora de la Facultad de Ciencias

Agrarias y Forestales

\title{
Fusarium: Producción de toxinas en granos de cebada y su interacción con Brachypodium
}

\author{
Alumna: Lic. María Soledad Nogueira \\ Director: Dr. Sebastián Alberto Stenglein \\ Co-directora: Dra. María Virginia Moreno
}

Laboratorio de Biología y Biotecnología (BIOLAB AZUL) - UNICEN

Agosto de 2019

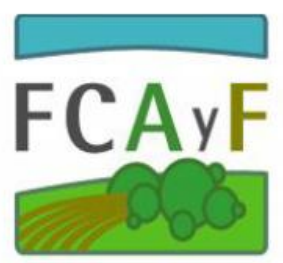




\section{Agradecimientos}

- A Sebastián por la confianza, la enseñanza y la empatía.

- A Virginia por los consejos y los aportes valiosos.

- A Cecilia por el asesoramiento y la predisposición.

- Al grupo de compañeros y compañeras por la ayuda, la compañia y la contención.

- A nuestra familia por el amor, el espacio, la paciencia y la confianza.

- A CONICET por la beca otorgada para desarrollar este trabajo de tesis doctoral.

- $\quad$ AI PICT 2011/030 (FONCYT-SECYT) y el PIP 2014-Nº 0551 (CONICET), subsidios otorgados al Dr. Stenglein que permitieron financiar este trabajo y a la UNCPBA por facilitar el espacio y el apoyo. 


\section{Índice general}

\section{CAPÍTULO 1:}

Introducción general

CAPÍTULO 2:

Materiales y Métodos

\section{CAPÍTULO 3:}

Especies de Fusarium aisladas de granos de cebada y determinacipon de micotoxinas relacionadas

\section{CAPÍTULO 4:}

Evaluación de las interacciones entre ecotipos de Brachypodium distachyon y especies de Fusarium en raíces

\section{CAPÍTULO 5:}

Conclusión y perspectivas finales 


\section{Índice}

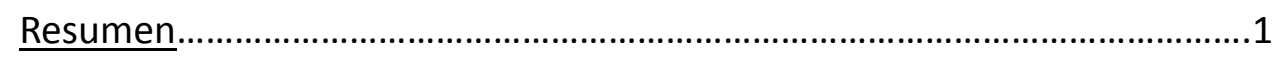

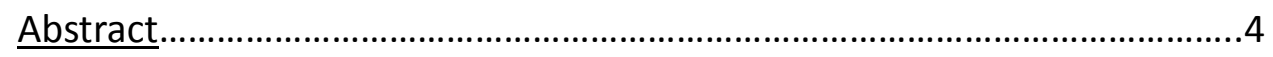

Capítulo I: Introducción general............................................................

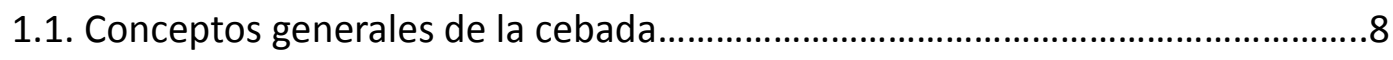

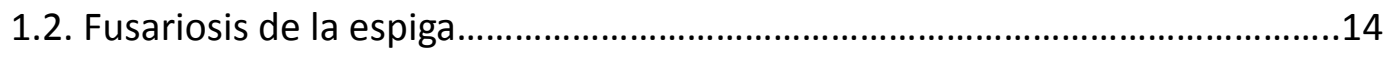

1.3. Género Fusarium - Especies de Fusarium en cereales....................................20

1.4. Técnicas moleculares de identificación de especies de Fusarium .....................26

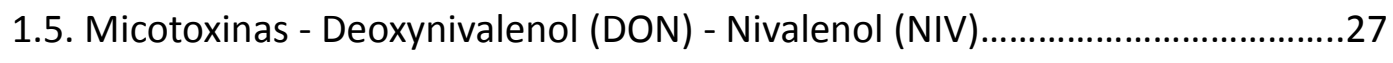

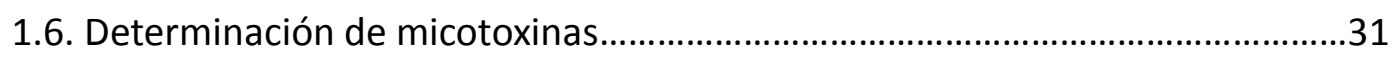

1.7. Regulación de micotoxinas en el mercado....................................................38

1.8. Interacciones entre Fusarium y hospedante..................................................41

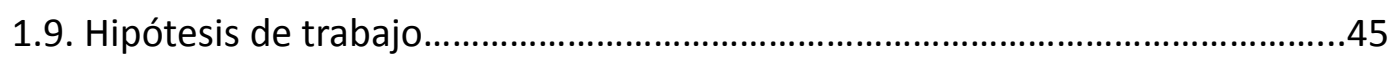

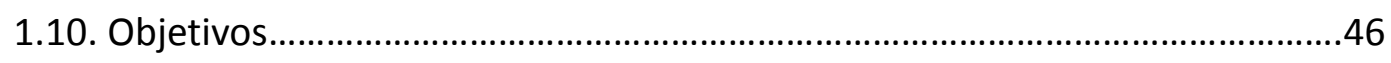

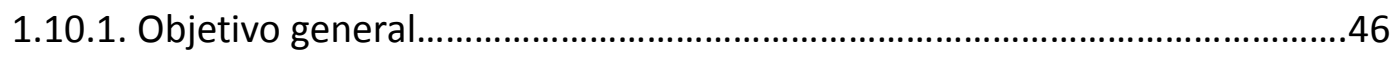

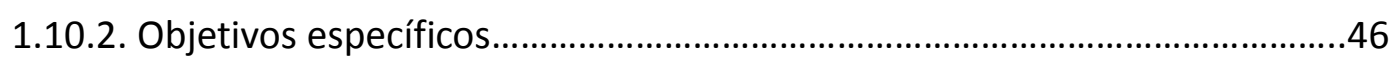

Capítulo Il: Materiales y Métodos.............................................................47

2.1. Obtención de las muestras de cebada a analizar.............................................48 
2.2.1. Aislamiento

2.2.2. Identificación morfológica.

2.2.3. Identificación molecular .52

2.2.3.1. Extracción de ADN

2.2.3.2. Reacciones en cadena de la polimerasa.

2.2.3.3. Secuenciación del factor de elongación 1- $\alpha$ .55

2.3. Micotoxinas

2.3.1. Potencial producción de toxinas.

2.3.2. Determinación de micotoxinas.

2.4. Datos climáticos

2.5. Análisis estadístico.

2.6. Fusarium / Brachypodium distachyion.

2.6.1. Obtención y selección de los ecotipos de Brachypodium distachyon. .61

2.6.2. Selección de los aislamientos a inocular .62

2.6.3. Ensayo de interacción 63

2.6.3.1. Preparado de inóculo .63 
2.6.4. Análisis estadístico

Capítulo III: Especies de Fusarium aisladas de granos de cebada y determinación de micotoxinas

3.1. Diversidad de Fusarium y micotoxinas.

3.1.1. Especies de Fusarium presentes en los granos de cebada y potencial producción de toxinas

3.1.2. Contaminación de los granos con micotoxinas

3.1.3. Relación entre presencia de Fusarium y micotoxina. .85

3.1.4. Datos climáticos .86

3.2. Discusión .88

Capítulo IV: Evaluación de las interacciones entre ecotipos de Brachypodium distachyon y especies de Fusarium en raíces .94

4.1. Fusarium / Brachypodium distachyon . .95

4.1.1. Comportamiento de aislamientos de Fusarium en raíces de Brachypodium

4.1.2. Análisis de especies de Fusarium. .98

4.1.3. Susceptibilidad de los distintos ecotipos de Brachypodium .99 
Capítulo V: Conclusiones y perspectivas finales.

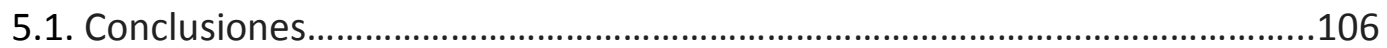

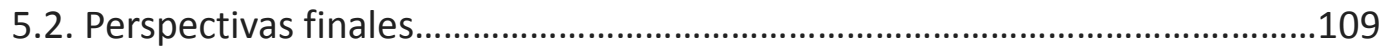

Referencias bibliográficas.........................................................................110

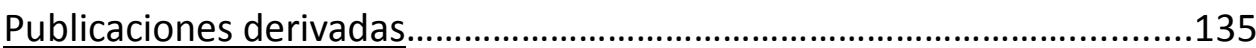

Anexo 


\section{Índice de figuras}

Figura 1. Cultivo de cebada en la zona del centro de la Provincia de Buenos

Aires. .9

Figura 2. Espiga de dos hileras (izquierda) y espiga de seis hileras (derecha)

Figura 3. Triángulo de las enfermedades .15

Figura 4. Rastrojo en siembra directa. 16

Figura 5. Espiga y granos de cebada infectados con Fusarium .18

Figura 6. Ciclo de la enfermedad. .19

Figura 7. Morfología de macroconidios, microconidios y estructuras morfológicas utilizadas para la identificación de especies...... .21

Figura 8. Técnica por ELISA 32

Figura 9. Técnica por flujo lateral. . .34

Figura 10. Proceso de separación de analitos por HPLC. 37

Figura 11. Distribución geográfica de las localidades muestreadas. .49

Figura 12. Placas de APG incubadas con granos de cebada con diversos hongos desarrollados. .50

Figura 13. Placa con CLA y tubo con APG pico de flauta con Fusarium poae de 10 días de crecimiento. 51 
Figura 14. Distribución del origen de los datos climáticos recopilados .60

Figura 15. Distribución geográfica de ecotipos de Brachypodium distachyon utilizados para el ensayo de interacción. .62

Figura 16. Procesado del micelio y el Agar Agua para la producción del slurry...64

Figura 17. Multiplicación de semillas, ejemplar de Brachypodium .65

Figura 18. Preparado de las placas 66

Figura 19. Siembra de semillas sobre placas con papel de filtro..... .66

Figura 20. Pasaje de semillas de Brachypodium distachyon de $4{ }^{\circ} \mathrm{C}$ a cámara de crecimiento 67

Figura 21. Incubación de las placas en cámara de crecimiento con luz y humedad controlada. 67

Figura 22. Inoculación de raíces 68

Figura 23. Incubación de raíces con slurry durante 2 días en cámara de crecimiento 69

Figura 24. Lavado de raíces con agua estéril...... .69

Figura 25. Diversidad y porcentaje de especies de Fusarium presentes en las muestras analizadas. .73

Figura 26. Observaciones microscópicas y tubo pico de flauta de las distintas especies de Fusarium aisladas de los granos de cebada .75

Figura 27. Porcentaje de muestras con o sin Fusarium graminearum y/o Fusarium poae .76 
Figura 28. Localidades muestreadas y presencia de Fusarium graminearum y/o Fusarium poae. 82

Figura 29. Porcentaje de muestras con o sin deoxynivalenol (DON) y/o nivalenol (NIV). 84

Figura 30. Precipitación acumulada, temperatura media y humedad relativa en el período de floración de la cebada (15 de octubre al 15 de noviembre). .87

Figura 31. Necrosis en raíces de Brachypodium distachyon inoculadas con aislamientos de Fusarium graminearum, Fusarium pseudograminearum, Fusarium cerealis y Fusarium poae fotografiadas a los 8 días después de la inoculación. .96 


\section{Índice de tablas}

Tabla 1. Pares de cebadores especie específicos utilizados para la identificación molecular de las distintas especies de Fusarium aisladas. .54

Tabla 2. Número de muestra, Genotipo de cebada, Localidad, Provincia y año de cosecha, concentración de micotoxinas presente y porcentaje de aislamientos de Fusarium graminearum y Fusarium poae sobre el total de aislamientos de Fusarium por muestra. .77

Tabla 3. Porcentajes de muestras con micotoxinas por año de muestreo. Desoxynivalenol (DON); Nivalenol (NIV). .85

Tabla 4. Temperaturas medias, precipitaciones acumuladas y humedades relativas de las localidades representativas al muestreo durante los años muestreados... .86

Tabla 5. Análisis de la varianza del AUDPC de la necrosis causada por Fusarium en raíces de Brachypodium distachyon.

Tabla 6. Interacción entre ecotipos de Brachypodium distachyon y aislamientos de Fusarium .100 


\section{Abreviaturas y siglas}

$\underline{\text { Siglas/abreviaturas }}$

- 3-ADON

- 15-ADON

- ADN

- ADNr

- ANOVA

- ANVISA

- APG

- AUDPC

$-B d$

- CLA

$-\mathrm{cm}$

$-\mathrm{CR}$

- CTAB

- DON

- dpi

- DTT

- EC

- EDTA

- ELISA

- FAO

$-F C$

- $F G$

- FGSC

\section{$\underline{\text { Significado }}$}

3 acetil-DON

15 acetil-DON

ácido desoxirribonucleico

ADN ribosomal

análisis de la varianza

Agencia Nacional de Vigilancia Sanitaria

agar papa glucosado

avance del progreso de la enfermedad del cultivo

Brachypodium distachyon

agar Clavel

centímetro

podredumbre de la corona

cetil-trimetil-bromuro de amonio

deoxynivalenol

días pos-inoculación

ditiotreitol

Comisión de Regulación

etilen-diamonio-tetra-acetato

Ensayo de inmuno-adsorción vinculado a enzimas

Organización de las Naciones Unidas para la agricultura y la alimentación

Fusarium cerealis

Fusarium graminearum

complejo de especies de Fusarium graminearum 
- FP

- FPS

- g

- GC

- HT-2

- HPLC

- hs

$-I A C$

$-|B|$

- IDTP

- INTA

- kg

- LOAEL

$-M$

$-\min$

$-\mathrm{ml}$

$-\mathrm{mM}$

- Mpb

- mtSSU

$-\mathrm{M} / \mathrm{O}$

$-\mathrm{NaCl}$

- n.d.

- NIV

$-\mathrm{NN}$

- NOAEL

- OMS

$-p b$

- PCR
Fusarium poae

Fusarium pseudograminearum

gramos

cromatografía de gases

toxina HT-2

cromatografía líquida de alta precisión

horas

columna de inmunoafinidad

International Brachypodium Initiative

ingesta diaria tolerable provisional

Instituto Nacional de Tecnología

Agropecuaria

kilogramo

mínimo nivel con efecto adverso observable

molar

minuto

mililitro

milimolar

mega bases

subunidad pequeña mitocondrial

microscopio óptico

cloruro de sodio

no detectado

nivalenol

dato no disponible

nivel sin efecto adverso observable

Organización Mundial de la Salud

pares de bases

reacción en cadena de la polimerasa 


\begin{tabular}{|c|c|}
\hline - PVP & polivinil-pirrolidona \\
\hline - qPCR & PCR cuantitativa \\
\hline - rpm & revoluciones por minuto \\
\hline - SEM & error estándar de la media \\
\hline - SPE & $\begin{array}{l}\text { limpieza con columna de extracción } \\
\text { en fase sólida }\end{array}$ \\
\hline - spp & especies \\
\hline$-\mathrm{TE}$ & Tris EDTA \\
\hline$-\mathrm{TLC}$ & cromatografía de capa fina \\
\hline - Tris-HCl & Buffer Tris ácido clorhídrico \\
\hline$-\mathrm{T}-2$ & toxina $\mathrm{T}-2$ \\
\hline$-\mu g$ & microgramo \\
\hline$-\mu l$ & microlitro \\
\hline$-\mu m$ & micrometro \\
\hline - USDA & $\begin{array}{l}\text { Departamento de Agricultura de los } \\
\text { Estados Unidos }\end{array}$ \\
\hline - UV & ultravioleta \\
\hline$-v$ & volumen \\
\hline - ZEA & zearalenona \\
\hline$-{ }^{\circ} \mathrm{C}$ & grados centígrados \\
\hline
\end{tabular}




\section{Resumen}

La cebada es uno de los cereales con mayor importancia tanto a nivel nacional como a nivel mundial y, en nuestro país, uno de sus principales destinos es la industria cervecera. Muchos estudios demuestran que este cultivo suele contaminarse por hongos que producen mermas en el rendimiento, poder germinativo y en algunos casos, toxinas nocivas para la salud, dentro de los cuales se puede citar al género Fusarium. Actualmente, en la Argentina y gran parte del mundo, se ha observado que las especies predominantes en granos de cebada son F. graminearum y F. poae. Estas dos especies producen toxinas dentro del grupo de los tricotecenos, principalmente Deoxynivalenol (DON) y Nivalenol (NIV), respectivamente. La Comunidad Europea establece como límite máximo en granos sin procesar $1,25 \mu \mathrm{g} / \mathrm{g}$ de DON, sin estar aún establecido el límite máximo para NIV, siendo esta última más tóxica que la primera. Estas toxinas no sólo pueden estar presentes en los granos sin procesar, sino que además son estables luego de procesos comunes de elaboración de alimentos y bebidas. Para poder caracterizar el comportamiento de este patógeno tan importante a nivel agronómico y alimenticio, se han realizado estudios de interacciones entre diferentes especies de Fusarium patógenas de flor/grano, utilizando el huésped y el tejido del cual se aisló el hongo.

El objetivo de este trabajo, por un lado, fue determinar la presencia de Fusarium, identificar las especies presentes, caracterizar su potencial producción toxigénica y cuantificar las toxinas antes mencionadas, en muestras de cebada 
provenientes de las principales zonas productoras de nuestro país, durante las campañas 2012, 2013 y 2014. Las muestras se redujeron y se sembraron 200 granos previamente desinfectados en placas con APG al $2 \%$ con cloranfenicol y se incubaron en cámara de crecimiento durante 5 días, aproximadamente. Los aislamientos obtenidos se identificaron morfológicamente y se corroboraron por PCR especie-específica. A su vez, se procesaron 50 gramos de muestra y se cuantificaron las micotoxinas por HPLC.

Se identificaron 1180 aislamientos de Fusarium en las 119 muestras analizadas, un $51,2 \%$ de F. graminearum, $26.2 \%$ de $F$. poae y $22.6 \%$ de otras especies. Se encontraron altas concentraciones de micotoxinas, con valores máximos de $12 \mu \mathrm{g} / \mathrm{g}$ de DON y $7.71 \mu \mathrm{g} / \mathrm{g}$ de NIV. De las muestras, $23 \%$ contenian DON a un promedio de $2.36 \mu \mathrm{g} / \mathrm{g}$, las cuales un $44 \%$ excedían los límites máximos (promedio de $5.24 \mu \mathrm{g} / \mathrm{g}$ ); el 29 \% contenía NIV con un promedio de 2,36 $\mu \mathrm{g} / \mathrm{g}$; el $7 \%$ contenía tanto DON como NIV; y el $55 \%$ no contenian DON o NIV. Finalmente, se reportó la contaminación por micotoxinas de las muestras de granos producidas por F. graminearum y F. poae, siendo las especies de Fusarium más frecuentes presentes. Se identificaron las principales especies de Fusarium que afectan los granos de cebada malteada en Argentina y se documento la presencia de muchas muestras con concentraciones elevadas de DON y NIV. Se cree que esta investigación fue la primera en cuantificar la contaminación por Fusarium y sus toxinas en muestras de cebada en Argentina. Se evidencia la necesidad de establecer controles de contenidos de Fusarium/toxinas en cebada. 
Por otro lado, formando parte del objetivo del presente trabajo, se evaluó las respuestas de raíces de distintos ecotipos de Brachypodium distachyon a Fusarium spp. para proporcionar información sobre las diferencias en la susceptibilidad del hospedante y/o la agresividad fúngica. Se seleccionaron un total de 10 aislamientos de cuatro especies de Fusarium: F. graminearum, F. pseudograminearum, F. cerealis y F. poae. Se utilizaron un total de siete ecotipos de B. distachyon: Afganistán, Irán, Israel, Pakistán, Sudáfrica, Uruguay y ecotipo Bd 21. Se inocularon las raíces y se midió la necrosis de raíz a los 2, 4, 6 y 8 días después de la inoculación. Los resultados mostraron que F. graminearum fue la especie con el valor más alto de AUDPC seguido de F. pseudograminearum y $F$. cerealis mostró un valor intermedio de AUDPC. Fusarium poae presentó valores de AUDPC más bajos. Con respecto a Brachypodium, el ecotipo menos afectado fue $\mathrm{Bd} 21$, mientras que los ecotipos restantes difirieron en la susceptibilidad. Por lo que se sabe, este es el primer informe que indica la interacción entre $F$. pseudograminearum, F. cerealis y F. poae con las raíces de Brachypodium. Además, se informó la variabilidad en la susceptibilidad entre los ecotipos de Brachypodium y en la agresividad de distintos aislamientos de Fusarium. Se concluye que las raíces de $B$. distachyon ofrecen un modelo de sistema de tejido eficiente para evaluar la interacción con Fusarium spp. 


\begin{abstract}
Barley is one of the most important cereals both nationally and globally and, in our country, one of its main destinations is the brewing industry. Many studies show that this crop is usually contaminated by fungi which cause loss in yield, germination power and in some cases, toxins that are harmful for health, among which the genus Fusarium can be mentioned. In Argentina and a great part of the world it has currently been observed that the predominant species in barley grains are F. graminearum and F. poae. These two species produce toxins within the group of trichothecenes, mainly Deoxynivalenol (DON) and Nivalenol (NIV), respectively. The European Community establishes as a maximum limit in unprocessed grains $1.25 \mu \mathrm{g} / \mathrm{g}$ of DON whereas the maximum limit for NIVhas not been established yet. The latter being more toxic than the former. These toxins may not only be present in raw grains, but are also stable after common food and beverage manufacturing processes. In order to characterize the behaviour of this important pathogen at the agronomic and nutritional level, interaction studies have been conducted among different flower/grain pathogenic Fusarium species, using the host and the tissue from which the fungus was isolated.
\end{abstract}

The purpose of this work was, on the one hand, to determine the presence of Fusarium, identify the species present, characterize its potential toxigenic production and quantify the before mentioned toxins, in barley samples from the main producing areas of our country during the 2012, 2013 and 2014 growing seasons. The samples were reduced and 200 previously disinfected grains were sown in plates with $2 \%$ PGA with chloramphenicol and incubated in a growth chamber for approximately 5 days. The isolates obtained were morphologically identified and corroborated by species-specific 
PCR. In turn, 50 grams of sample were processed and mycotoxins were quantified by HPLC.

From the 119 samples analyzed, 1180 Fusarium isolates were identified, 51.2\% from F. graminearum, $26.2 \%$ from $F$. poae and $22.6 \%$ from other species. High concentrations of mycotoxins were found, with maximum values of $12 \mu \mathrm{g} / \mathrm{g}$ of DON and $7.71 \mu \mathrm{g} / \mathrm{g}$ of NIV. $23 \%$ of the samples contained DON at an average of $2.36 \mu \mathrm{g} / \mathrm{g}$, of which $44 \%$ exceeded the maximum limits (average of $5.24 \mu \mathrm{g} / \mathrm{g}$ ); $29 \%$ contained NIV with an average of $2.36 \mu \mathrm{g} / \mathrm{g} ; 7 \%$ contained both DON and NIV; and a 55\% neither DON nor NIV. Finally, mycotoxin contamination of grain samples produced by F. graminearum and F. poae was reported, being the most frequent Fusarium species present. The main Fusarium species that affect malted barley grains in Argentina were identified and the presence of many samples with high concentrations of DON and NIV was documented. It is believed that this investigation was the first to quantify contamination by Fusarium and its toxins in barley samples in Argentina. The need to establish controls of Fusarium/toxin content in barley is evident.

On the other hand, forming part of the purpose of this work, the responses of roots of different ecotypes of Brachypodium distachyon to Fusarium spp. to provide information on differences in host susceptibility and/or fungal aggressiveness were evaluated. 10 isolates of four Fusarium species were selected: F. graminearum, F. pseudograminearum, F. cerealis and F. poae. A total of seven B. distachyon ecotypes were used: Afghanistan, Iran, Israel, Pakistan, South Africa, Uruguay and ecotype Bd 21. Roots were inoculated and root necrosis was measured at 2, 4, 6 and 8 days after the inoculation. The results showed that $F$. graminearum was the species with the highest AUDPC value followed by F. pseudograminearum and F. cerealis showed an intermediate 
AUDPC value. Fusarium poae presented lower AUDPC values. Concerning to Brachypodium, the least affected ecotype was $B d 21$, while the remaining ecotypes differed in susceptibility. As far as it is known, this is the first report indicating the interaction among $F$. pseudograminearum, F. cerealis, and F. poae with the roots of Brachypodium. Besides, variability in the susceptibility between Brachypodium ecotypes and in aggressiveness of different Fusarium isolates were reported. It is concluded that the roots of $B$. distachyon offer an efficient tissue system model to evaluate the interaction with Fusarium spp. 


\section{CAPÍTULO I:}

\section{Introducción general}




\subsection{Conceptos generales de la cebada}

La cebada (Hordeum vulgare L.) es una monocotiledónea de la familia Poaceae que, a lo largo de la historia, ha tomado mucha importancia a nivel alimenticio tanto para animales como para humanos (Figura 1). Esto propicia a que su importancia agronómica también crezca. La cebada es una gramínea que desciende de la cebada silvestre (Hordeum spontaneum K. Koch), oriunda de Medio Oriente, es una planta de hojas estrechas y color verde claro. Su apariencia es muy similar a la planta del trigo, aunque esta es sutilmente más oscura y suele ser más erguida en los primeros estadíos de su desarrollo. La espiga, que corresponde a la prolongación del último internudo del tallo, presenta un raquis central que está compuesto por 10 a 30 nudos y está formada por espiguillas, las cuales van dispuestas de a tres en forma alterna a ambos lados del raquis. Si todas las espiguillas se presentan fértiles se originará una espiga de seis hileras, si sólo resultan fértiles las espiguillas centrales, se originará una espiga de dos hileras (Figura 2). La cebada es una planta autógama, sus flores tienen tres estambres y un pistilo de dos estigmas. Estas abren después de haberse realizado la fecundación, lo cual favorece a la conservación de los caracteres de un genotipo determinado. El grano de cebada tiene forma puntiaguda, más grueso en el centro y afinado hacia los extremos. 


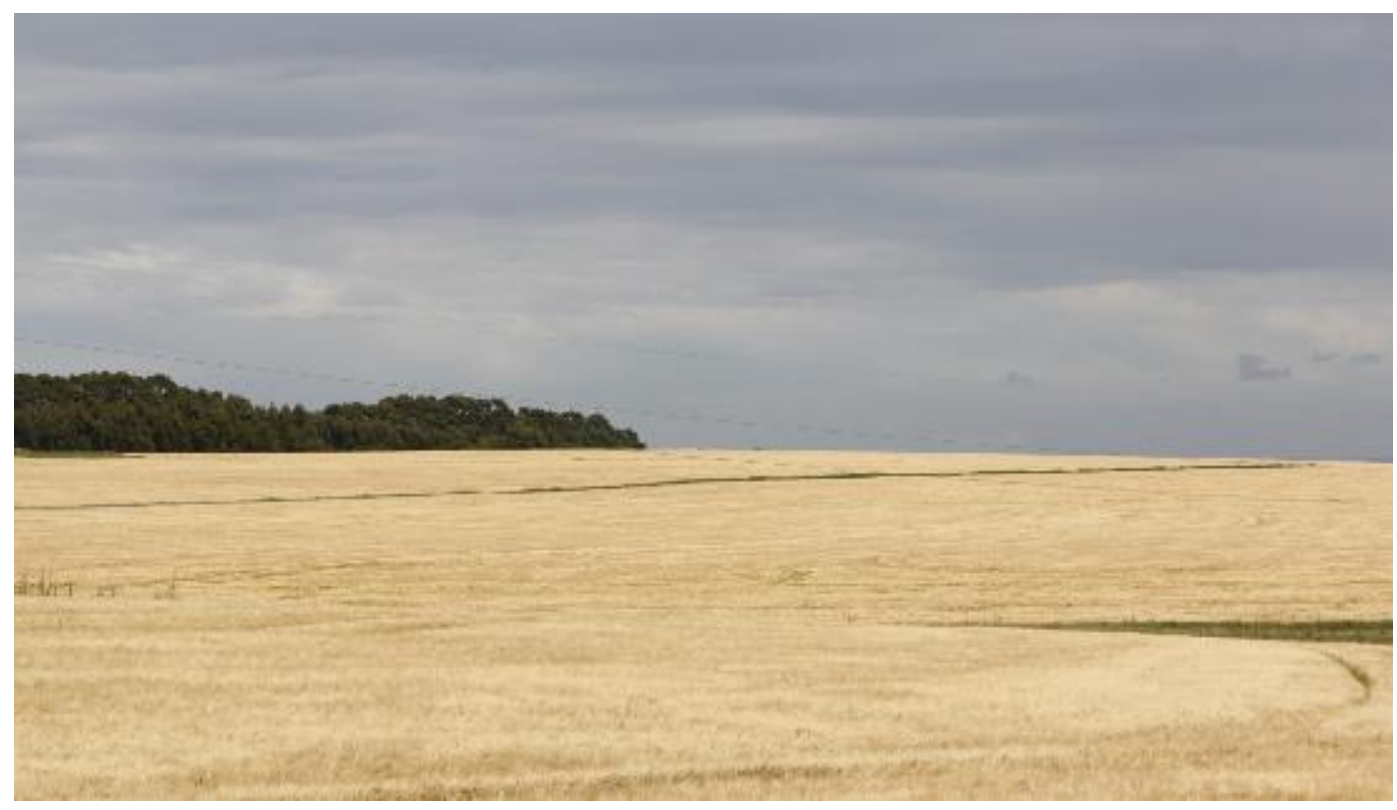

Figura 1. Cultivo de cebada en la zona del centro de la Provincia de Buenos Aires.

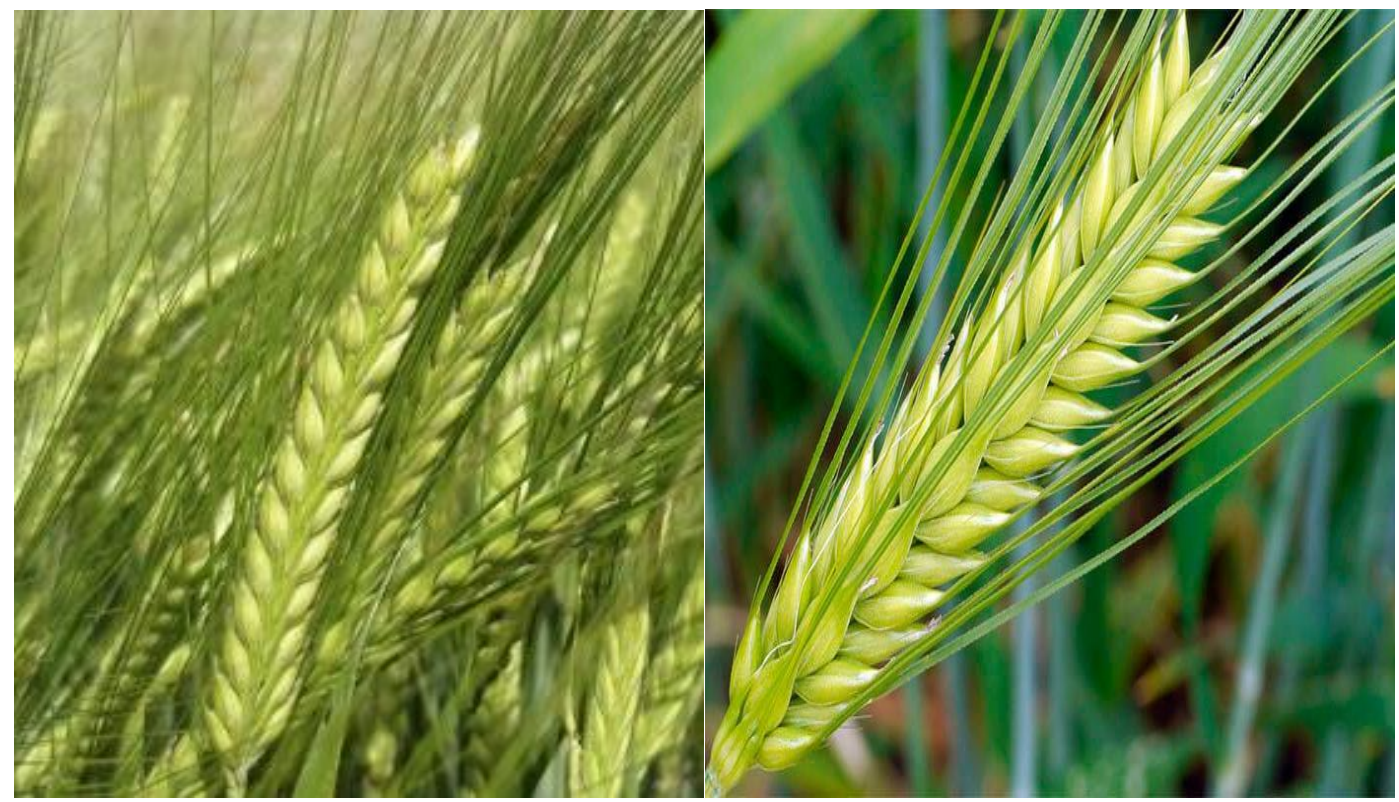

Figura 2. Espiga de dos hileras (izquierda) y espiga de seis hileras (derecha). 
El principal destino de la producción de cebada en todo el mundo es la alimentación animal y humana. La cebada que se emplea para la elaboración de cerveza se denomina Hordeum vulgare L. var. distichum L. mientras que la que se usa como forraje para la alimentación animal se denomina Hordeum vulgare L. var. hexastichum L. (Ibarguren, 2014). En términos prácticos, la cebada se clasifica de acuerdo con el uso a que se destina (cervecera o forrajera) y el tipo de espiguilla (de dos y seis hileras). En general, los cultivares de 6 hileras son consideradas forrajeras, ya que producen abundante masa verde y sus granos tienen un mayor porcentaje de proteínas, siendo apropiados para la alimentación animal. Los granos de cebada con altos niveles de proteínas se tornan del tipo indeseable para la industria maltera, ya que esta exige niveles más bajos (Baldanzi, 1988).

La cebada es un cereal de invierno que en estas latitudes se siembra en los meses de junio, julio y en la primera quincena de agosto (dependiendo la zona). La cosecha se realiza en noviembre, diciembre y, eventualmente, los primeros días de enero. Existen muchos genotipos de cebada en la producción mundial actual. El genotipo Scarlett, de origen alemán, ocupa alrededor del $70 \%$ de la producción argentina de cebada, favorecida por la homogeneidad del grano que brinda. El resto de la producción nacional corresponde principalmente a los genotipos Shakira y Andreia (alemanas), Quilmes Carisma o Qcarisma (argentinas), y Scrabble y Explorer (francesas).

La producción mundial total de cebada en la campaña 2017/2018 fue de 
aproximadamente 146 millones de toneladas (Bolsa de Comercio de Rosario, 2018), y el Departamento de Agricultura de los Estados Unidos (USDA) estimó que la cifra para 2018/2019 fue de aproximadamente 140 millones de toneladas. Esto muestra una baja del $4 \%$ aproximadamente en la producción mundial, debido a que, en varios países productores, la cebada padeció condiciones secas y calurosas en agosto y principios de septiembre del 2018. De manera similar a lo ocurrido con el cultivo de trigo, la falta de agua, combinada con altas temperaturas en periodos claves del cereal, afectó a los rendimientos y a la calidad del grano obtenido (Bolsa de Comercio de Rosario, 2018).

En la actualidad, la producción de cebada fue evolucionando ya que es una atractiva opción comercial en el mercado y también porque beneficia la estructura de los suelos cuando es utilizada para rotarla con otros cultivos. Los principales productores de cebada son la Unión Europea (con 57 millones de toneladas) y Rusia (con 16,5 millones de toneladas), siendo Argentina la octava a nivel mundial (con 4 millones de toneladas) (Cebada Cervecera, 2019). Datos analizados por la USDA en el 2017, muestran a Argentina en el quinto puesto a nivel mundial de exportadores de cebada con un volumen de 1,7 millones de toneladas.

En Argentina, el área sembrada este año aumentó un $17 \%$ con respecto a la campaña 2017/18, siendo la Provincia de Buenos Aires la zona más importante cultivada: el $40 \%$ del total nacional se obtiene en el sudeste bonaerense y otro $30 \%$ en el centro/norte. El porcentaje restante se obtiene en el sudeste de La 
Pampa, sur de las Provincias de Córdoba, Santa Fe y Entre Rios (ReTAA, 2019). A diferencia de la cebada cervecera, la cebada forrajera se desarrolla mejor en el sudoeste de Buenos Aires y centro/sur de las Provincias de La Pampa y Córdoba, compitiendo con la alfalfa, el centeno, la avena, el triticale y el ryegrass.

Con respecto a la cebada destinada a la producción de cerveza, su uso se debe a su alto contenido de almidón y a que la cáscara (tegumentos) permanece adherida al grano, lo que facilita el filtrado para la obtención del mosto. Esto es importante ya que antes de ser usada en cervecería, la cebada debe primero ser convertida en malta y su cáscara es un importante filtro para la extracción del mosto. El proceso de malteado se puede sintetizar como una germinación controlada y se define a la malta como el grano de cebada germinado, secado, desraizado y desbrotado. La calidad de los granos tiene una influencia directa en la calidad del producto final. Las características deseables de la cebada para malteado se concentran en: pertenecer a un mismo genotipo, granos de tamaño uniforme y brillantes, ausencia de granos pelados y rotos, porcentaje de proteínas entre 10 y 12,5\%, bajo contenido de humedad, germinación pareja (más de $95 \%$ ), alto porcentaje de extracto fermentable. Una de las principales exigencias en la producción de malta es la uniformidad, ya que esto facilita la sincronización del proceso de germinado de cada grano.

La cebada, como otros cultivos, puede sufrir estrés durante su crecimiento. El rendimiento potencial de los cultivos de cebada se ve afectado por el estrés biótico, causado por enfermedades, plagas y malezas, pero también 
por el estrés abiótico, relacionado con las condiciones ambientales como excesos o falta de humedad, de temperatura y/o de radiación. Dentro de los llamados estrés bióticos, es de gran impacto la presencia de agentes infecciosos que provocan enfermedades (patógenos), tales como son algunos hongos, bacterias y/o virus. Las bacterias patógenas de granos son un problema que impacta económicamente en todo el mundo ya que pueden causar importantes pérdidas, son responsables de las enfermedades reemergentes, del traslado de patógenos de un continente a otro y de la introducción de enfermedades en nuevas áreas. Los virus causan muchas e importantes enfermedades vegetales y son responsables también de pérdidas en el rendimiento y la calidad de los cultivos en todas partes del mundo. La mayoría de los virus vegetales son transmitidos en forma activa de una planta infectada a otra sana por un organismo vivo, Ilamado vector. A diferencia de las bacterias, la supervivencia de relativamente pocos virus a largo plazo (incluso por décadas) se da en el ambiente o por la transmisión mecánica pasiva de una planta a otra (Gergerich \& Dolja, 2006).

Los hongos son el principal grupo de patógenos que pueden afectar a los cultivos, pudiendo causar efectos adversos en distintos órganos de las plantas, como la raíz, tallo, hoja y fruto. Los hongos que se pueden encontrar en los granos de cebada varían dependiendo de una serie de factores que incluyen el clima, las condiciones de cultivo, las prácticas agrícolas, la fertilización, el suelo y también las condiciones de almacenamiento de poscosecha (Noots et al., 1999). La cebada puede estar dañada por hongos patógenos y/o no patógenos. Un alto nivel de infección con especies fúngicas como por ejemplo del género Fusarium o 
Penicillium en granos de cebada ha demostrado una correlación significativa con una baja calidad de las maltas resultantes (Kaur et al., 2015). Dentro de las enfermedades, una de las más importantes en los cultivos de gramíneas causada por hongos es la fusariosis de la espiga. A causa de su frecuencia y severidad, esta enfermedad es una de las principales enfermedades de los cereales de grano chico a nivel mundial (McMullen et al., 1997).

\subsection{Fusariosis de la espiga}

Para los que se encuentran relacionados con el crecimiento de las plantas, agricultores y trabajadores agrícolas e industrias de derivados del cereal, es de gran interés el buen desarrollo de las mismas. Pero la sanidad de ellas debería ser aún más importante ya sea por el rendimiento de los cultivos como por la calidad del producto y las consecuencias ambientales ocasionadas durante su producción. Este es un punto que nos convoca a todos, ciudadanos, productores, consumidores y no consumidores.

La presencia de agentes patógenos en un determinado hospedante necesita de condiciones ambientales favorables para que se desarrolle una determinada enfermedad (Agrios, 1999). Estos tres componentes forman lo que se conoce como "triángulo de las enfermedades". El cuarto componente, localizado en el centro del triángulo, es el productor. En un proceso productivo, es este el que modifica los tres componentes del esquema para favorecer la 
sanidad, la calidad y el rendimiento de su producción (Figura 3).

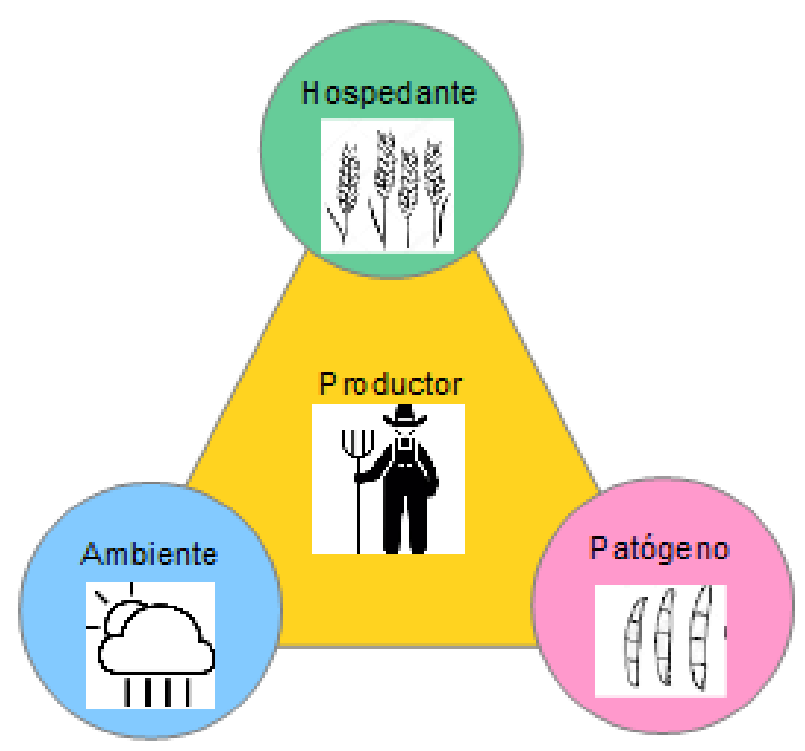

Figura 3. Triángulo de las enfermedades.

El crecimiento y el rendimiento de las plantas dependen de la disponibilidad del agua, de los nutrientes del suelo donde se desarrollan y de la utilización de algunas herramientas y/o manejos del/los cultivos. Algunos de estos manejos pueden ser la regulación de la temperatura, la luz y la humedad (en el caso de ser posible), las herramientas utilizadas para la labor, la utilización de productos para evitar la infección con virus (vectores), hongos y/o bacterias perjudiciales para la calidad del producto, etc. (Agrios, 1999)

La fusariosis de la espiga ocurre en todas las regiones cerealeras del mundo y causa serios daños económicos, especialmente en los cultivos de trigo (Triticum aestivum L.) y de cebada (McMullen et al., 1997). Es una enfermedad fúngica causada por algunas especies del género Fusarium. Las óptimas 
condiciones necesarias para que se desarrolle la enfermedad es un clima (ambiente) cálido y húmedo. Aunque, resulta necesario que estas condiciones coincidan con el período de floración o el período temprano de llenado del grano de los cultivos para favorecer la infección y desarrollo de la enfermedad. Esto se debe a que Fusarium infecta la espiga utilizando las flores como vía de entrada. Si bien las condiciones climáticas son claves en el desarrollo de la fusariosis, existen otros factores que contribuyen a la incidencia de la enfermedad. El empleo de la técnica de siembra directa, por ejemplo, implica la permanencia de grandes volúmenes de rastrojos de cultivos susceptibles u otras gramíneas, como son algunas pasturas y/o malezas (Figura 4). Estos representan una fuente de inóculo permanente sobre la superficie del suelo. En especial los rastrojos de trigo, cebada y maíz constituyen un reservorio importante de Fusarium e incrementan significativamente la carga de inóculo en los sistemas de producción.

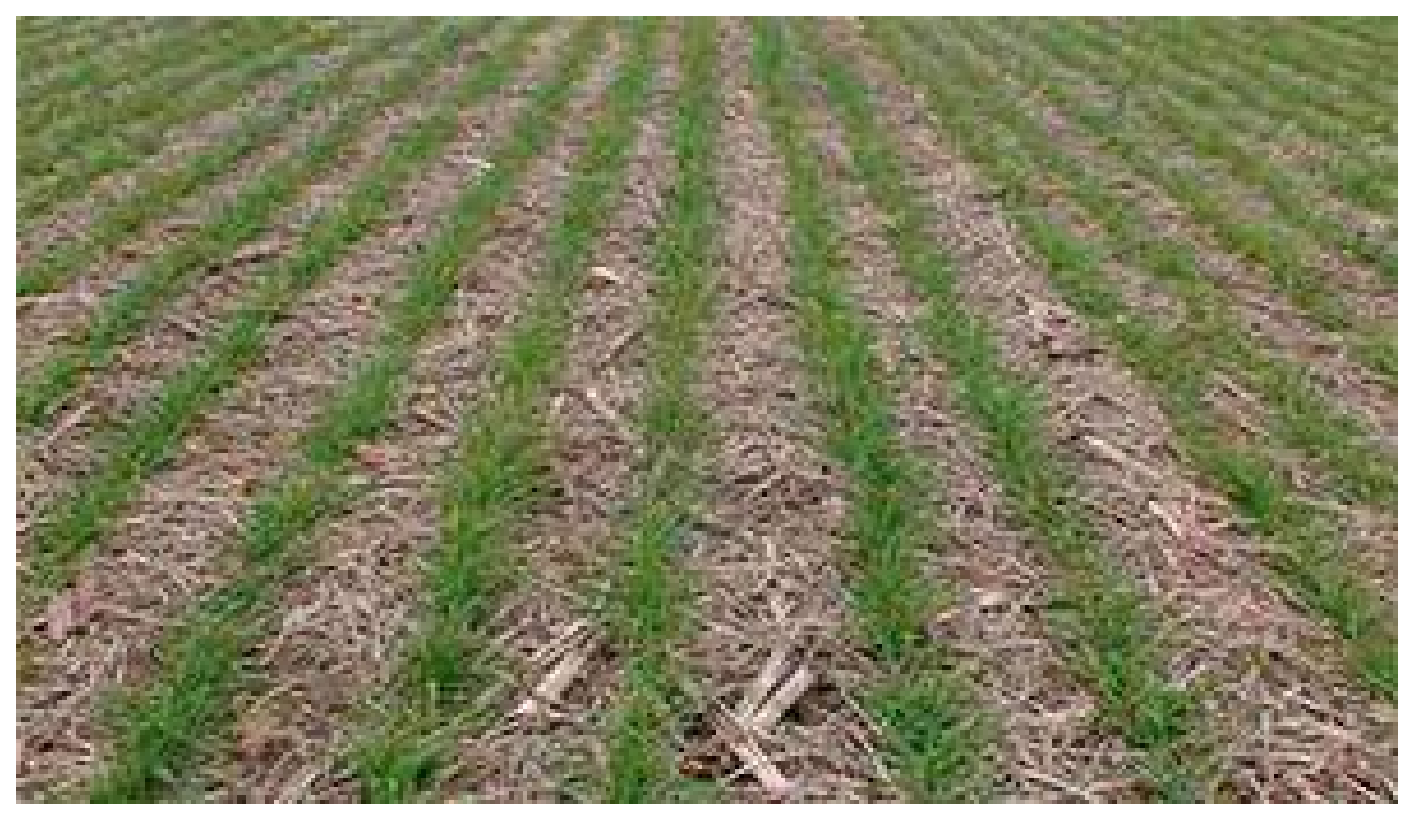

Figura 4. Rastrojo en siembra directa. 
La fusariosis de la espiga puede causar daños cuantitativos y cualitativos en la cebada mediante la reducción del rendimiento, disminución del poder germinativo y del vigor de los granos, disminución del tenor proteico en los granos y por la presencia de toxinas nocivas para la salud, llamadas micotoxinas (Mesterházy \& Bartók, 1996; Reis \& Carmona, 2002).

Esta enfermedad se evidencia principalmente en las espigas. En trigo, los síntomas son una decoloración prematura de las espiguillas infectadas, pudiendo llegar a tomar toda la espiga. Esto se debe a que, a partir de un foco de infección, Fusarium puede migrar de una espiguilla a otra a través del raquis y así expandir la enfermedad afectando la espiga entera. Esto no ocurre en la cebada, lo que representa, en general, una menor susceptibilidad a la fusariosis. Los síntomas en cebada aparecen como granos discretos, pardos, pardo-anaranjados, marrones, chuzos, distribuidos de manera discontinua en la espiga. La infección de Fusarium en cebada solo se puede extender desde las espiguillas infectadas a las adyacentes. En ambos cultivos, si las espiguillas han sido infectadas tempranamente, se desarrollan masas de esporas rosado-salmón y, eventualmente, estructuras oscuras al momento de la cosecha, llamados peritecios. Los granos infectados luego de cosechados se muestran más o menos chuzos, con una coloración blanco-rosada a pardo clara, llegando a ser pardo oscura en cebada. En una infección temprana, como se explicó anteriormente, Fusarium detiene el desarrollo de las flores, evitando la formación de los granos. En infecciones más tardías se producirán granos arrugados o chuzos (Figura 5). Si la infección ocurre luego del llenado del grano, el desarrollo del mismo no es 
afectado, pero el hongo está presente y los niveles de micotoxinas producidas por el mismo pueden llegar a ser significativos.

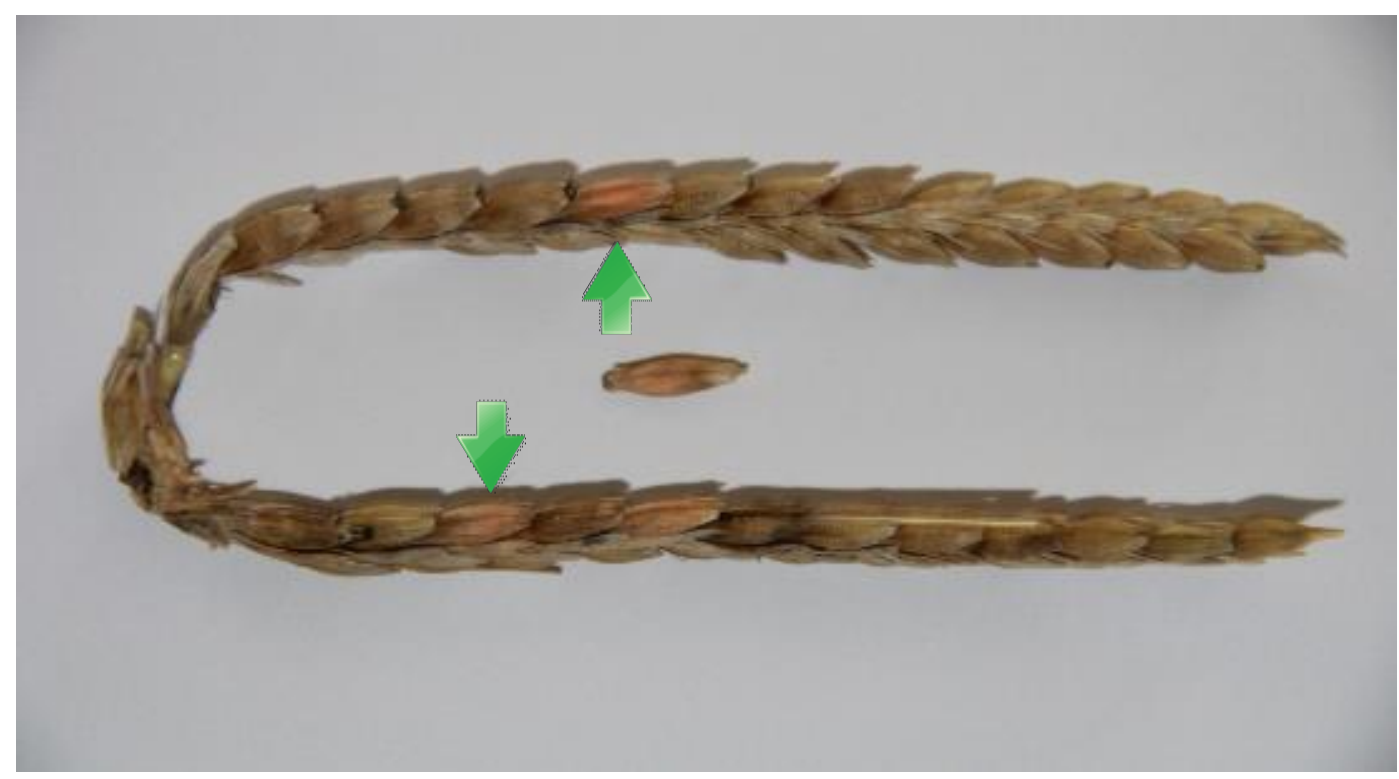

Figura 5. Espiga y granos de cebada infectados con Fusarium.

El ciclo de la enfermedad (se describe como ejemplo a la especie Fusarium graminearum) comienza cuando una o más especies de Fusarium, por dispersión del viento, agua (lluvia o riego), insectos y/o animales, infectan la planta cuando esta entra en antesis (Figura 6, modificado desde Trail, 2009). La liberación de las ascosporas se efectúa al hidratarse los peritecios. Este proceso es cíclico, depende del agua disponible y de la temperatura, y continúa hasta la completa descomposición del rastrojo. Las ascosporas diseminadas son depositadas sobre las anteras. En particular, la colonización de la espiga ocurre desde la antesis hasta grano pastoso (Zadoks et al., 1974). Por esto, el período de susceptibilidad en la espiga queda limitado a 2 o 3 semanas. Una vez infectada y 
bajo condiciones de humedad, las espiguillas afectadas pierden clorofila y se cubren de micelio blanco. Luego, aparece una masa viscosa, extensa y de color salmón/naranja en la base y bordes de las glumas, que son las envolturas que rodean a las inflorescencias. Estas masas se denominan pionnotes y corresponden a los conidios asexuales del hongo (Mûller \& Loeffler, 1976). Si las condiciones ambientales son muy favorables, la infección avanza hacia las espiguillas adyacentes. En casos avanzados se llegan a formar peritecios. Posterior a la infección de las flores o los granos de cebada, el patógeno expresa genes para la síntesis micotoxinas, que son metabolitos secundarios. Una vez que la planta madura y es cosechada, los granos quedan infectados con Fusarium y posiblemente contaminados con micotoxinas, dependiendo de la o las especies presentes. Los rastrojos o residuos de cosecha de la planta también reservan parte del inóculo lo que permite una nueva infección en el cultivo siguiente, siempre y cuando sea susceptible a Fusarium.

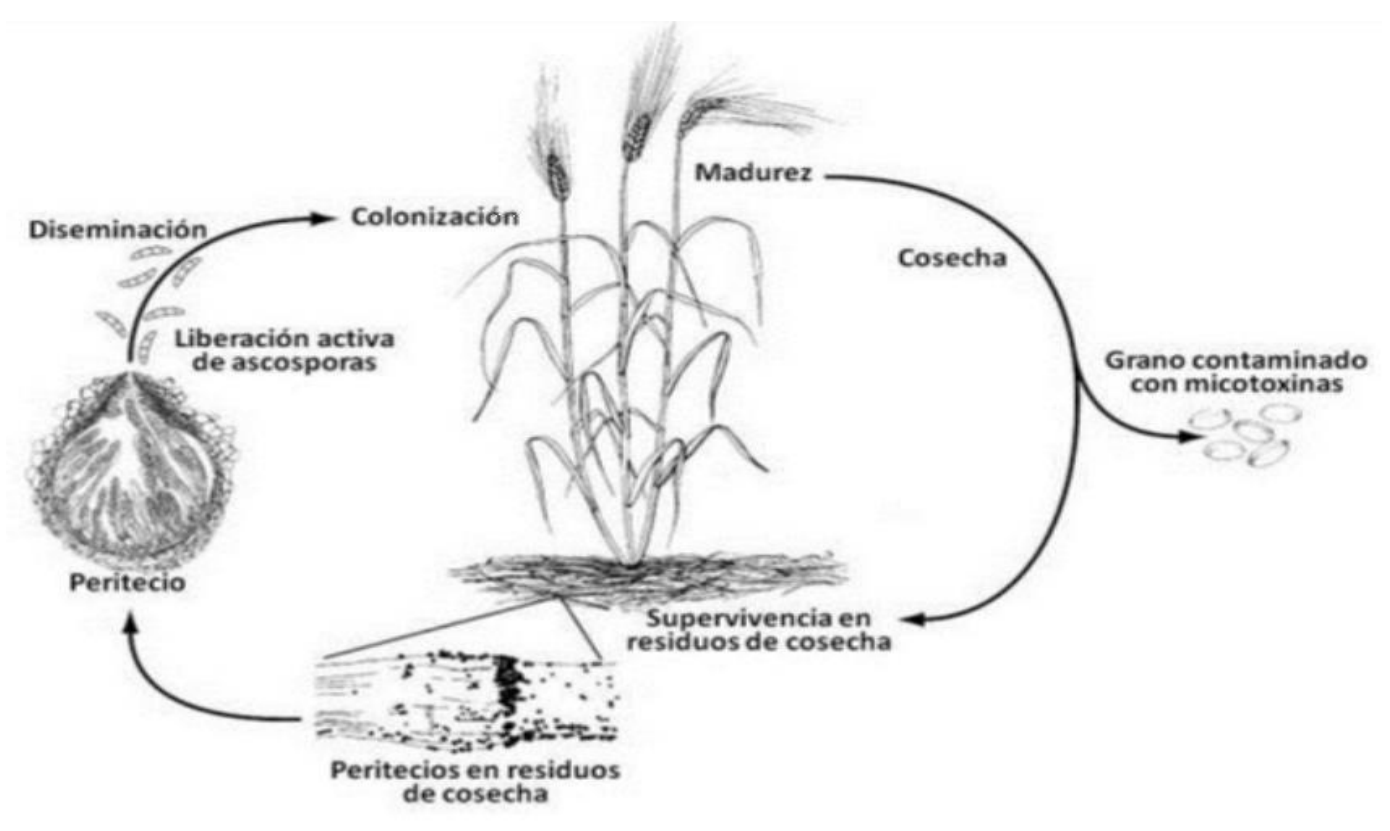

Figura 6. Ciclo de la enfermedad. 


\subsection{Género Fusarium - Especies de Fusarium en cereales}

Fusarium es un género fúngico muy diverso, se encuentra extendido y es comúnmente encontrado en todo el mundo. Estos hongos existen en suelos, animales y plantas vivas y muertas y es, probablemente, el género fitopatógeno y toxigénico más importante desde el punto de vista económico de los hongos filamentosos en cereales. En general, son saprófitos, porque se alimentan y descomponen residuos orgánicos, y son parásitos facultativos, ya que pueden parasitar a un determinado hospedante si se presentan condiciones favorables como humedad y temperaturas altas (Agrios, 1999)

El género Fusarium es un complejo de hongos que pertenecen al Phyllum Ascomycota, orden Hypocreales, familia Hypocreaceae. En 1809, el investigador alemán Link lo describió basándose en su principal característica, que es la presencia de conidios distintivos en forma de canoas o bananas. Este género tiene la característica de poseer hifas que llevan conidios llamadas conidióforos. Estos, al agruparse, forman los esporodoquios. Fusarium tiene la capacidad de producir tres tipos de esporas asexuales: dos tipos de conidios que se pueden encontrar en el mismo esporodoquio y se clasifican como macroconidios (con 1 a 7 tabiques) y microconidios (con 1 a 2 tabiques); y clamidosporas que son esporas de resistencia. Algunas especies producen microconidios y clamidosporas mientras que otras solo alguno de ellos, lo que resulta una característica útil al momento de identificarlas (Figura 7) (Leslie \& Sumemerell, 2006). 


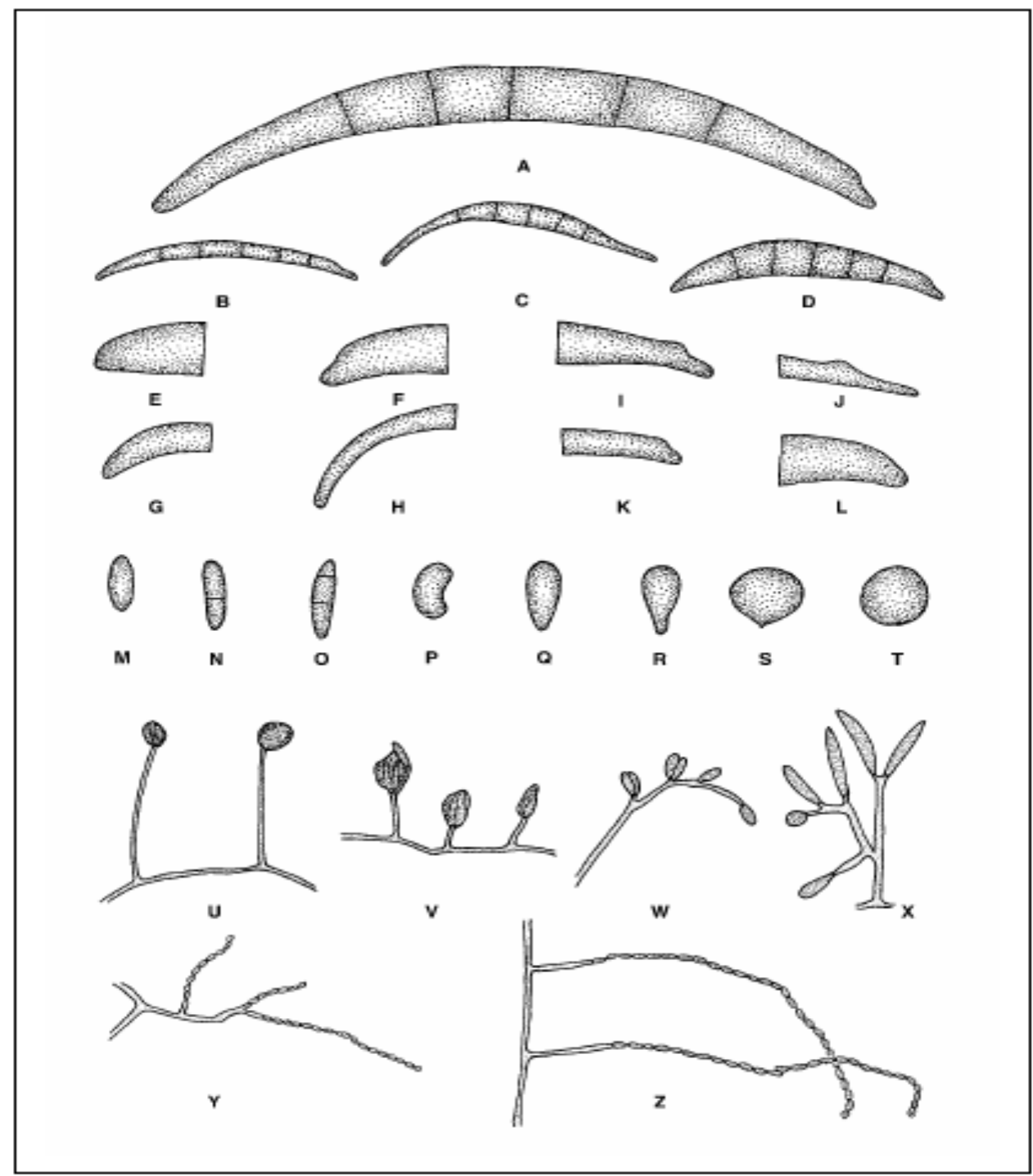

Figura 7. Morfología de macroconidios (A-L), microconidios $(M-T)$ y estructuras morfológicas utilizadas para la identificación de especie (U-Z).

Los macroconidios son las esporas principales en la caracterización, ya que su forma y tamaño varía de acuerdo a cada especie. Estas esporas son curvadas, pluriseptadas con una célula apical bien diferenciada, que puede ser redondeada, puntiaguda, filamentosa o en forma de gancho y poseen una célula 
basal en forma de pie. Los microconidios pueden ser unicelulares o bicelulares, en el proceso de identificación a nivel de especie se considera la presencia o ausencia de estas esporas, ya que no todas las especies del género Fusarium producen microconidios. Las clamidosporas son las esporas encargadas de la supervivencia del hongo. Estas pueden estar solas, en pares, en grupos o en cadenas. Las clamidosporas cuentan con una pared gruesa rugosa o lisa (Nelson et al, 1983; Leslie \& Sumemerell, 2006).

Varios conceptos son utilizados para definir una especie fúngica. En Fusarium, los conceptos de especies están basados sobre la morfología, los ensayos de entrecruzamiento o los datos moleculares, o en la integración de dos o tres de estos (Yli-Mattila et al., 2002). El concepto morfológico es el acercamiento clásico más usado por micólogos, y se define en base a características morfológicas y las diferencias entre ellas.

En el 1935, Wollenweber \& Reinking dividieron el género Fusarium en 16 secciones, 65 especies y 77 variedades. Esto lo hicieron agrupando las especies en cada sección según características morfológicas. Cincuenta años más tarde, y basándose en estas divisiones, Nelson et al. (1983) describieron 30 especies de Fusarium y ofrecieron una descripción menos detallada de 16 especies adicionales. En la actualidad, Leslie \& Summerell (2006) desarrollaron un manual en el que describieron 70 especies diferentes que permite identificarlas mediante claves y descripciones morfológicas.

Se han aislado especies de Fusarium toxigénicas y no toxigénicas de los 
cereales (trigo, cebada y avena) con síntomas de fusariosis de la espiga (D'Mello et al., 1999; Schwarz et al., 2003). En cuanto a especies patógenas, se han implicado al menos 17 relacionadas a esta enfermedad (Parry et al., 1995), las cuales son: Fusarium acuminatum, F. avenaceum, F. cerealis, F. culmorum, F. equiseti, F. graminearum, F. lateritium, F. moniliforme, F. nivale, F. oxysporum, F. poae, F. proliferatum, F. sambucinum, F. semitectum, F. sporotrichiodes, F. subglutinan y F. tricinctum. Actualmente, Fusarium graminearum es considerado un complejo (FGSC - "Fusarium graminearum species complex") formado por al menos 16 especies de Fusarium filogenéticamente definidas: $F$. austroamericanum (linaje 1), F. meridionale (linaje 2), F. boothii (linaje 3), F. mesoamericanum (linaje 4), F. acaciae-mearnsii (linaje 5), F. asiaticum (linaje 6), F. graminearum sensu stricto (F. graminearum s.s. linaje 7), F. cortaderiae (linaje 8) y F. brasilicum, F. vorosii, F. gerlachii, F. aethiopicum, F. ussurianum, F. louisianense, F. nepalense, Fusarium sp. (sin nombre asignado), a los cuales no se les ha asociado un número de linaje (Sarver et al. 2011; Aoki et al. 2012). De todas las especies que conforman este complejo, Fusarium graminearum sensu stricto (s.s.) es la principal causante de la fusariosis de la espiga en trigo en América y de cebada en Argentina (Castañares et al. 2014). Estudios realizados en trigo y cebada en Sudamérica identificaron otras cinco especies que afectan estos cultivos: F. asiaticum, F. austroamericanum, F. brasilicum, F. cortaderiae y $F$. meridionale en trigo y F. meridionale y F. austroamericanum en cebada (Álvarez et al. 2009; Scoz et al. 2009; Astolfi et al. 2011, 2012; Reynoso et al. 2011; Pan et al. 2013, Umpierrez-Failache et al. 2013; Del Ponte et al. 2015). 
Las especies predominantes en todo el mundo que pueden causar fusariosis de la espiga (o aislarse de granos que presentan o no síntomas típicos) son: Fusarium graminearum, F. culmorum, F. avenaceum y F. poae (Reis \& Carmona 2002). En Europa, F. graminearum fue la especie más aislada de granos de trigo en un área del centro de Italia, Bélgica, Noruega, Croacia Oriental y Holanda (Waalwijk et al., 2003; Audenaert et al., 2009; Spanic et al., 2010; Covarelli et al., 2015; Hofgaard et al., 2016), de cebada en Suiza (Schöneberg et al., 2016), y de trigo y cebada en Sudamérica (Angelotti et al., 2006; Álvarez et al., 2009; Reynoso et al., 2011; Umpierrez-Failache et al., 2013; Castañares et al., 2016). Otras especies de Fusarium, como F. pseudograminearum, son responsables de la fusariosis de la espiga en las regiones trigueras de Australia, aunque se ha informado con mayor frecuencia como un patógeno que afecta el sistema radical (Manning et al., 2000). Esta especie causa principalmente la enfermedad de la podredumbre de la corona que afecta al trigo en regiones como Australia, Túnez, Sudáfrica y Nueva Zelanda donde prevalecen las condiciones climáticas secas (Monds et al., 2005; Desmond et al., 2006; Lamprecht et al., 2006; Gargouri et al., 2011). En Argentina, Álvarez et al. (2011) y Castañares et al. (2012) describieron el primer informe de F. pseudograminearum causando fusariosis de la espiga en trigo y cebada, respectivamente. Esta especie es capaz de producir también micotoxinas.

En Europa, los granos de cereales frecuentemente están contaminados por especies de Fusarium como F. culmorum, F. avenaceum y F. poae. Aunque, generalmente, el contaminante más común es $F$ graminearum 
(Nicholson et al., 2003). Sin embargo, la presencia de distintas especies de Fusarium está sujeta a cambios climáticos a lo largo de un período de años y a prácticas agrícolas, como las aplicaciones de pesticidas y la fertilización con nitrógeno (Beccari et al., 2017; Schöneberg et al., 2016). En Suecia, F. avenaceum fue la especie con mayor incidencia en los granos de trigo, seguida por F. poae, mientras que F. graminearum fue la más abundante (Karlsson et al., 2017). En la región de Umbría, en el centro de Italia, Beccari et al. (2016) encontraron que la especie de Fusarium predominante en los granos de cebada fue F. avenaceum, seguida de F. graminearum y $F$. poae. En un estudio de campo de tres años, $F$. poae fue la especie más frecuente, seguida por F. incarnatum - F. equiseti (complejo), F. graminearum y F. avenaceum (Beccari et al., 2017).

Entre todas las especies de Fusarium, F. cerealis y F. poae se han considerado como patógenos menores entre las especies capaces de producir fusariosis de la espiga. Se ha reportado que F. cerealis causa podredumbre roja en el maíz en Europa, en trigo en el este de Estados Unidos y se aisló de granos de cebada en Argentina (Logrieco et al., 2003; Schmale et al., 2011; Castañares et al., 2013). De manera similar, F. poae es otra especie de Fusarium comúnmente aislada de varios sustratos, considerada por algunos autores como uno de los principales productores de micotoxinas (Rotter et al., 1996; Covarelli et al., 2015; Nogueira et al., 2018). 


\subsection{Técnicas moleculares de identificación de especies de Fusarium}

La identificación de especies de géneros fúngicos es una práctica cotidiana en grupos de investigación estrictamente o vinculados con la micología. A grandes rasgos se puede clasificar, por un lado, las técnicas de identificación morfológica (o técnicas tradicionales) y, por el otro, técnicas de identificación molecular. Para el género Fusarium, las técnicas de identificación morfológica más comúnmente empleadas son las propuestas por Leslie \& Summerell (2006) como se mencionó anteriormente.

Varias pruebas de diagnóstico molecular han sido desarrolladas para la identificación y detección de los principales hongos implicados en la fusariosis de la espiga (Koopman et al., 1994; Ouellet y Siefert, 1993; Parry y Nicholson, 1996). La mayoría de estos se basan en el uso de la reacción en cadena de la polimerasa (PCR). Para esta técnica se utilizan cebadores específicos donde se pueden diferenciar especies del género Fusarium. Estos cebadores pueden estar diseñados en base a ADN de genes multicopia, ya que presentan una mayor sensibilidad al estar con una concentración mayor en la muestra (como en reacciones especie específicas para la identificación de Fusarium poae).

Otro método de identificación molecular radica en la amplificación de regiones conservadas del genoma, características de cada especie, mediante reacciones de PCR y su posterior (o no) secuenciación del fragmento amplificado. En muchos organismos, el ADN mitocondrial tiene una tasa de evolución más alta 
que el ADN nuclear (Brown et al., 1979). Esta tasa es aproximadamente 16 veces mayor en el gen de ADNr de la subunidad pequeña mitocondrial (mtSSU) que en el gen de $A D N r$ de la subunidad pequeña nuclear en 10 especies de hongos (Bruns y Szaro, 1992). Lo que respecta al ADN fúngico, se conoce que los motivos de la secuencia del gen del factor de elongación 1-alpha (EF-1a) se pueden utilizar para la identificación de especies y estudios de linaje de Fusarium (Geiser et al. 2004; Kristensen et al., 2005). Comparaciones de marcadores filogenéticos en Fusarium demuestran que el gen EF-1a posee considerablemente más información filogenética que el mtSSU (O’Donnell et al. 1998). Gracias a estos estudios, hoy en día se conoce que la combinación de EF-1a y otros genes proporcionan mayor información entre y dentro de los linajes, como el gen de la tubulina, calmodulina, etc.

\subsection{Micotoxinas - Deoxynivalenol (DON) - Nivalenol (NIV)}

Las micotoxinas son "metabolitos fúngicos secundarios cuya ingestión, inhalación o absorción cutánea reduce la actividad, hace enfermar o causa la muerte de animales (sin excluir las aves) y personas" (Pitt, 1996). Son un grupo de metabolitos de bajo peso molecular que producen algunos hongos y que contaminan cereales con los que se produce alimento tanto para humanos como para animales. Estos hongos, responsables de la producción de las micotoxinas, han crecido en algún momento del ciclo de cultivo o de la etapa inicial del 
almacenamiento (Moss, 1989).

Una micotoxina se considera "importante" si se ha demostrado su capacidad para tener efectos sobre la salud de las personas y la sanidad de los animales en diversos países del mundo. Para determinar el umbral de las relaciones entre la dosis y la respuesta a una micotoxina hay que identificar el nivel sin efecto adverso observable (NOAEL) o el mínimo nivel con efecto adverso observable (LOAEL). Otro parámetro utilizado en el estudio de las micotoxinas es la dosis segura a ser ingerida por el humano. Para esto, se introduce el concepto de ingesta diaria tolerable provisional (IDTP) (Soriano del Castillo, 2007).

Los géneros fúngicos mayormente asociados a la producción de micotoxinas son Aspergillus, Penicillium y Fusarium. Ciertas especies de Fusarium son productoras potenciales de tricotecenos, toxinas que son peligrosas para la salud de humanos y animales a través de la asociación con ciertas patologías, por ejemplo, emesis y rechazo de alimentación o pérdida de apetito, entre otras consecuencias negativas (D'Mello et al., 1999; Desjardins, 2006). Los tricotecenos son tóxicos potentes de las células eucarióticas y causan lesiones dérmicas, alteraciones de la respuesta inmunológica e inhibición de la síntesis de macromoléculas, con acción letal en dosis altas (Desjardins et al. 1993). Una característica muy importante para la industria alimenticia es que no se degradan en el procesamiento normal de alimentos (Eriksen, 2003). Estas micotoxinas se dividen según su estructura química en 4 categorías: $A, B, C$ y D. Los tricotecenos producidos por el género Fusarium pertenecen a los grupos $A$ y $B$. Los del tipo $A$ 
incluye toxinas como la toxina T-2 y toxina HT-2, mientras que los del tipo B incluye al deoxynivalenol (DON), sus acetil derivados como 3-acetildeoxinivalenol (3-ADON), 15-acetildeoxinivalenol (15-ADON), nivalenol (NIV), y fusarenona $X$ producidos, principalmente, por F. graminearum, F. culmorum, F. cerealis y F. poae (Fernández Pinto et al. 2013).

El DON, que también es conocido como vomitoxina debido a brotes de síndrome emético en ganado (Omurtag \& Beyoglu, 2003), es la micotoxina producida mayormente por Fusarium graminearum y F. culmorum. Es una micotoxina que contamina cereales como maíz, trigo, arroz, centeno y cebada y se encuentra normalmente en productos como cereales de desayuno, aperitivos, malta, cerveza y pan (Comisión Europea, 1999). Es muy estable durante el almacenamiento poscosecha, molienda del grano y procesado de las harinas resultantes. Se conoce que su estabilidad se mantiene hasta los $121^{\circ} \mathrm{C}$, presenta leve inestabilidad a los $180{ }^{\circ} \mathrm{C}$ y se logra una completa inactivación cuando permanece por 10 minutos a $370{ }^{\circ} \mathrm{C}$. En condiciones ácidas se mantiene inalterada, siendo inactivada en presencia de hipoclorito de sodio al $3 \circ 5 \%$ (Ehling et al., 1997; Cirillo et al., 2033; Hazel \& Patel, 2004; Lori y Rizzo, 2007). La Organización Mundial de la Salud (OMS) la considera como una toxina teratogénica, neurotóxica e inmunosupresora. Los efectos críticos que produce el DON fueron evaluados en ratones y cerdos, demostrando que con niveles entre 0,04 y $0,375 \mu \mathrm{g} / \mathrm{g}$ no se observan efectos tóxicos (NOAEL). Con respecto a su ingestión en humanos, se han relacionado micotoxicosis con niveles de esta toxina entre 3 y $93 \mu \mathrm{g} / \mathrm{g}$. Los síntomas observados fueron náuseas, vómitos, 
trastornos gastrointestinales, vértigo y dolor de cabeza (Pestka, 2010). Del grupo de los tricotecenos, el DON es la micotoxina más frecuente de la dieta humana (Wartha et al., 2012).

EI NIV es una micotoxina menos estudiada que el DON en cuanto a su genotoxicidad y sus mecanismos de toxicidad. Son micotoxinas estructuralmente muy similares pero la toxicidad es muy diferente, siendo el NIV 10 veces más tóxico que el DON. Principalmente, es producido por Fusarium cerealis y F. poae, aunque también puede producirla especies como $F$. culmorum y especies del complejo F. graminearum. Se suele hallar en la mayoría de los cereales y productos que suele encontrarse el DON. En humanos, puede estar relacionada con hemorragia pulmonar y cerebral y lesión de la médula ósea a través de la interrupción de la síntesis del ADN y proteínas. Según Forsell y Petska (1985), el NIV es linfotóxico al inhibir células B y T. También se lo relaciona a la inhibición de la síntesis de proteínas por interferir en la función ribosomal en conejos (Ueno \& Fukushuma, 1968). En suero de ratones, Choi et al. (2000) demostraron que esta micotoxina puede inhibir el antígeno específico lgE (efectores de anticuerpos en la alergia). El efecto de esta toxina se evaluó también en líneas celulares de macrófagos de monocitos murinos, cuyos resultados determinaron un fuerte efecto citotóxico en las líneas celulares utilizadas, que se podría atribuir a una aceleración de la vía apoptótica (Marzocco et al., 2009). 


\subsection{Determinación de micotoxinas}

Para la determinación de micotoxinas se utilizan distintas técnicas según las necesidades de especificidad, la muestra a analizar y la disponibilidad de recursos. Una de ellas, es la técnica basada en la unión específica de antígeno (micotoxina)-anticuerpo, donde un antígeno específico puede distinguir la estructura tridimensional de una única micotoxina. Esta técnica Ilamada ELISA (Ensayo de inmuno-adsorción vinculado a enzimas) es una de las más utilizadas en análisis de rutina. La micotoxina es extraída de la muestra molida con un solvente y luego se mezclan una parte del extracto de la muestra y la micotoxinaenzima-conjugado (Figura 8a). La mezcla es colocada en un pocillo recubierto con anticuerpos (Figura 8b). La toxina de la muestra y los estándares de control compiten con el conjugado por los sitios de unión de los anticuerpos (Figura 8c). Luego de un lavado (Figura 8d), se agrega el sustrato para la enzima que tiñe de color azul la mezcla (Figura 8e). La intensidad del color es inversamente proporcional a la concentración de la toxina en la muestra o al estándar. Para detener la reacción y poder medir la concentración de micotoxina, se agrega un "stop" a la solución y esta se torna amarilla (Figura 8f) (la Figura 8 esta modificada desde Zheng et al., 2006). La medición se realiza utilizando un lector ELISA con un filtro de absorbancia de $450 \mathrm{~nm}$ y se comparan la densidad óptica de la muestra con las de los estándares. 


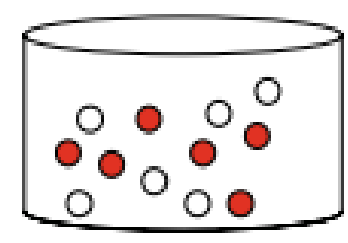

(a)

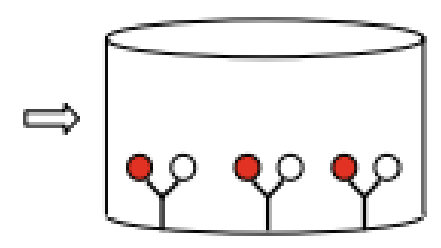

(d)

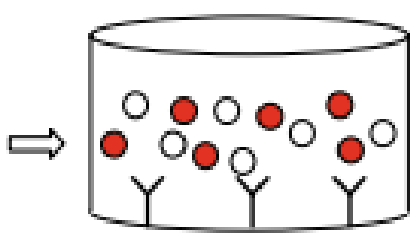

(b)
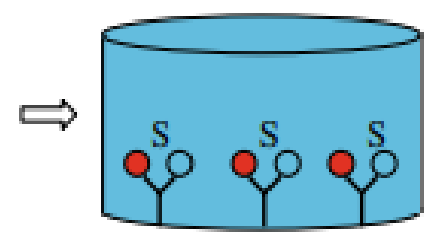

(e)

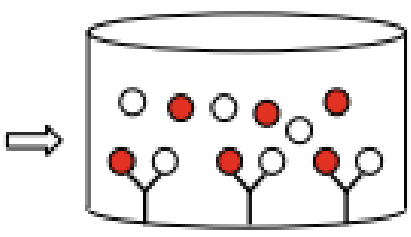

(c)

Figura 8. Técnica por ELISA. Los círculos rojos representan la micotoxina, los círculos representan la micotoxina-enzima-conjugado, las " $\mathrm{Y}$ " representan los anticuerpos y las "S" representan el sustrato.

El uso de estos kits de detección por ELISA es una alternativa simple, económica y altamente específica, que tiene la ventaja adicional de ser portables (se pueden llevar a campo) (Zheng et al., 2004). Aunque, los anticuerpos son muy sensibles y específicos, y también pueden interactuar con la matriz de la muestra subestimando o sobrestimando la concentración de micotoxinas en algunos casos (Trucksess \& Koeltzow, 1995). Como consecuencia, este inmunoensayo se limita a algunos tipos de muestras, principalmente cereales, y no está validado para alimentos balanceados (Zheng et al., 2006). Además, dado que esta técnica es semicuantitativa, la interpretación de los resultados puede ser difícil cuando la concentración de micotoxinas de la muestra está cerca del nivel de corte del método. 
Otra técnica de determinación de micotoxinas es la prueba inmunocromatográfica de flujo lateral. Esta se ha utilizado durante muchos años, aunque es bastante reciente en pruebas de micotoxinas (Zheng et al., 2006). Una tira de prueba de inmunocromatografía típica se compone de una almohadilla de muestra, una almohadilla de conjugado, una membrana, una almohadilla absorbente y un respaldo adhesivo (Figura 9a). El esquema de reacción competitiva se usa con mayor frecuencia cuando se analizan moléculas pequeñas con determinados antigénicos, como las micotoxinas (Figura 9b). Se añade el extracto a analizar en la almohadilla de muestra. Cualquier micotoxina presente se une al complejo de anticuerpo anti-micotoxina en la almohadilla de conjugado y migran junto con el complejo segundo anticuerpo anti-micotoxina a lo largo de la membrana. La membrana contiene una zona de prueba y una zona de control, las cuales contienen un conjugado de micotoxina-proteína y un 2do anticuerpo, respectivamente. El conjugado de micotoxinas-proteínas en la zona de prueba puede capturar cualquier complejo de partículas libres de anticuerpos antimicotoxina, permitiendo que las partículas de color se concentren y formen una línea visible. Por lo tanto, una muestra positiva con una concentración de micotoxinas mayor o igual al nivel de corte del ensayo no dará como resultado una línea visible en la zona de prueba. A la inversa, una muestra negativa con una concentración de micotoxinas menor al nivel de corte formará una línea visible en la zona de prueba. La zona de control siempre será visible, independientemente de la presencia o ausencia de micotoxinas, ya que el 2do anticuerpo siempre captura el complejo anticuerpo anti-micotoxina que indica la 
validez de la prueba realizada. Los beneficios de esta prueba son que es fácil de usar, muy rápida, tiene estabilidad a largo plazo y es portable. Sin embargo, esta técnica solo puede proporcionar resultados semicuantitativos (como los proporcionados mediante ELISA) y, para muestras positivas, la concentración exacta de micotoxinas requeriría confirmación mediante otro método.

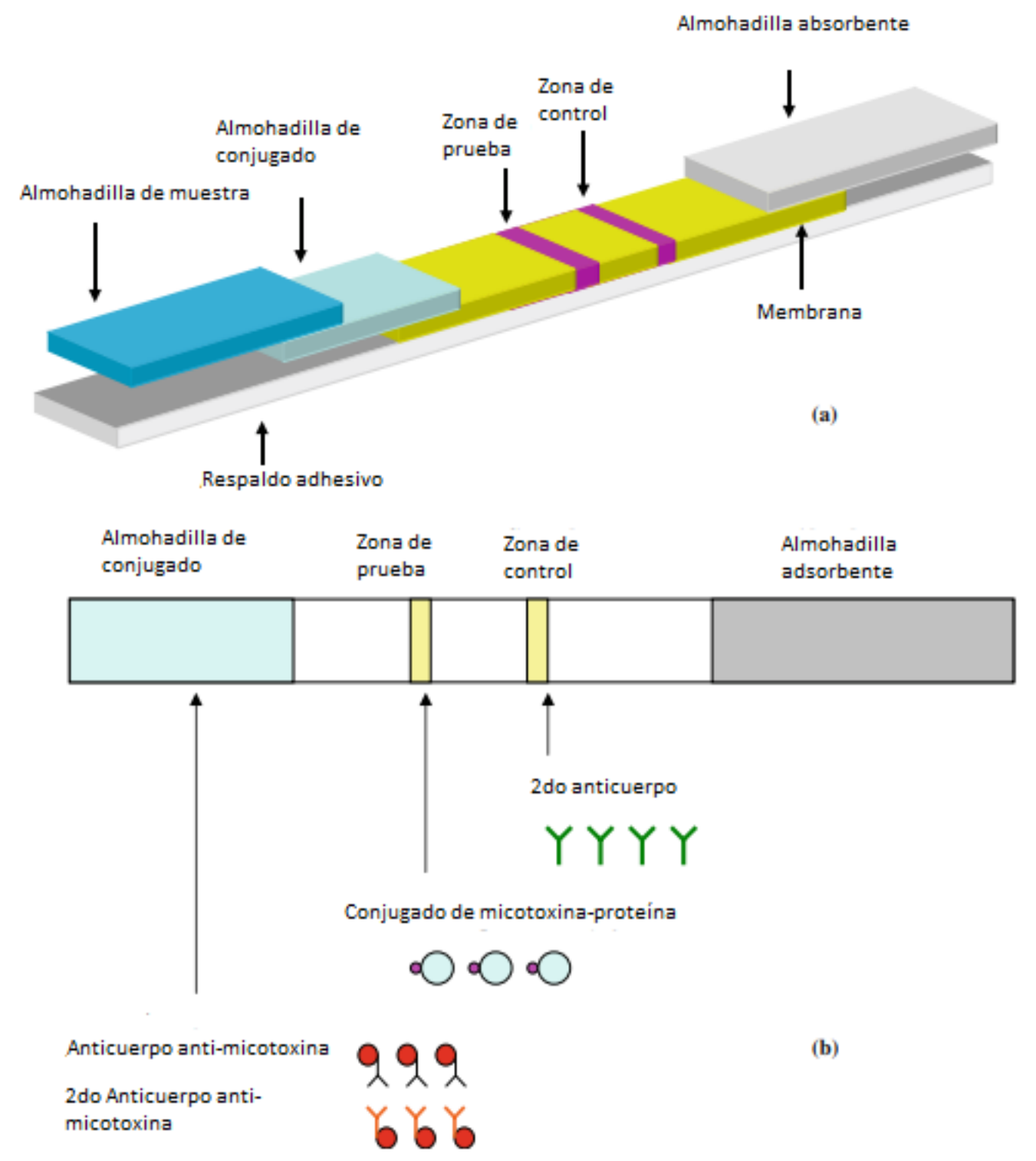

Figura 9. Técnica por flujo lateral. Composición de una tira de prueba de inmunocromatografía típica (a). Esquema de reacción competitiva (b). 
El ensayo fluorométrico es otro método eficaz para el análisis de micotoxinas que ha estado disponible durante más de una década. A diferencia de los anteriores, este método es cuantitativo. Para obtener resultados de micotoxinas precisos mediante un ensayo fluorométrico, es muy importante eliminar las interferencias en las muestras antes de la medición ya que otros compuestos en el extracto pueden tener fluorescencia que podría alterar las lecturas. Los ensayos fluorométricos disponibles utilizan dos métodos de limpieza de muestras que han demostrado ser eficaces para eliminar las interferencias del ensayo: limpieza con columna de inmunoafinidad (IAC) y limpieza con columna de extracción en fase sólida (SPE). Utilizando las IAC, la micotoxina se puede concentrar en la columna, lo que aumenta la sensibilidad del ensayo fluorométrico o disminuye su límite de detección. Sin embargo, las IAC tienen una capacidad de carga limitada y los procedimientos de limpieza de la muestra son más complicados en comparación con otros métodos rápidos para micotoxinas. Las SPE se pueden usar para el análisis de multitoxinas por otros métodos. La columna tiene una vida útil prolongada porque no contiene reactivos biológicos y se puede almacenar a temperatura ambiente. A diferencia de las IAC, algunas columnas de SPE no pueden concentrar la micotoxina durante el procedimiento de limpieza, y también la recuperación puede variar dependiendo de la complejidad de la muestra.

Los métodos analíticos convencionales para las micotoxinas incluyen cromatografía de capa fina (TLC), cromatografía de gases (GC) y cromatografía líquida de alto rendimiento (HPLC). La mayoría de estos métodos emplean la 
limpieza con SPE de extractos y técnicas de inmunoafinidad para eliminar las interferencias y mejorar la medición de las micotoxinas. La GC fue desarrollada en 1941 como alternativa a la cromatografía líquida, sugiriendo que la fase móvil líquida podía ser reemplazada por un gas adecuado. Dicha recomendación fue basada en que, debido a la mayor difusión de los solutos en los gases, comparado con los líquidos, el proceso de equilibrio involucrado en los procesos cromatográficos puede ser mucho más rápido y así las columnas más eficientes y los tiempos de separación más cortos, aunque esta técnica resulta más costosa que el HPLC.

La técnica de HPLC se basa principalmente en la distribución de los componentes de una mezcla (harinas de granos o soluciones a base de alimentos), previamente limpiada, entre una fase fija (fase estacionaria) y otra que se desplaza (fase móvil). El proceso de separación entre dos o más analitos empieza cuando uno es retenido más fuertemente por la fase estacionaria que el/los otro/s, que tiende/n a desplazarse más rápido por la fase móvil (Figura 10).

Esta técnica involucra métodos con diferentes columnas de fase normal o fase reversa, soluciones y gradientes de elución distintos, métodos de detección, preparación de muestras y procedimientos de purificación donde las micotoxinas se caracterizan por el tiempo de retención (Rahmani et al., 2009). 

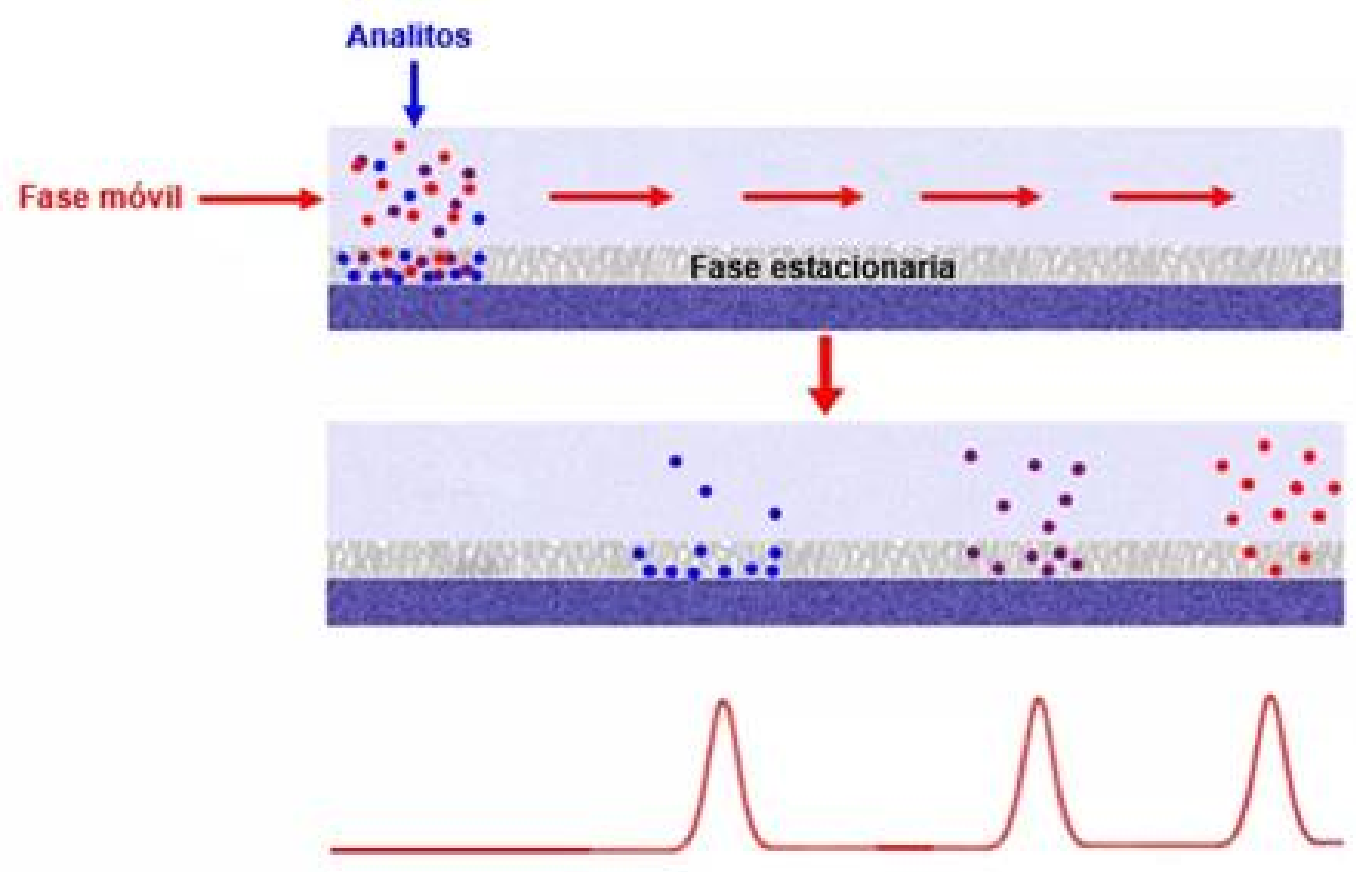

Figura 10. Proceso de separación de analitos por HPLC.

Actualmente, la técnica de HPLC es una de las más utilizadas en la cuantificación de micotoxinas por diversas razones. Si bien esta técnica requiere de instrumental y equipamientos costosos, sus procedimientos son relativamente sencillos y rápidos. Resulta ser muy específica dentro de las técnicas cuantitativas y es posible determinar varias micotoxinas de una misma muestra. Otra característica que resulta interesante es que su alta resolución permite obtener y separar compuestos de muestras mixtas. Esto permite que, en el mismo ensayo, se pueden identificar y cuantificar la/las toxina/s y, a su vez, recuperar para ensayos posteriores. 


\subsection{Regulación de micotoxinas en el mercado}

Las buenas prácticas agrícolas pueden reducir significativamente los factores de riesgo y hasta suelen prevenir la contaminación por hongos del género Fusarium. A pesar de esto, para proteger la salud pública es importante que se establezcan y regulen contenidos máximos de micotoxinas en cereales no elaborados, así como en alimentos procesados, ya que, como se explicó anteriormente, se conoce que muchas de estas son estables luego de procesos normales de elaboración de alimentos y bebidas, por lo tanto, es posible detectarlas no solo en alimentos sin procesar, sino también en los procesados.

La regulación de granos contaminados con micotoxinas varía entre regiones y/o países del mundo. En Europa, se ha establecido límites máximos de DON en granos no procesados (que no sean trigo duro, avena y maíz) a 1,25 $\mu \mathrm{g} / \mathrm{g}$, por parte de la Comisión de Regulación (EC) de las comunidades europeas (Regulación EC 1881/2006, Regulación EC 1126/2007). Sin embargo, aún no se ha establecido el límite máximo para NIV, siendo este último más complejo toxicológicamente hablando que el anterior. Según la Comisión Europea, la regulación de DON es suficiente para proteger a los consumidores de micotoxinas generadas por especies de Fusarium debido a la ocurrencia simultánea de estas. De manera similar, la Agencia de Vigilancia de la Salud de Brasil (Agencia Nacional de Vigilancia Sanitaria: ANVISA) estableció un límite de 1,00 $\mu \mathrm{g} / \mathrm{g}$ de DON en cebada malteada (ANVISA, 2017). En Uruguay, se establece límite máximo de 
$1,00 \mu \mathrm{g} / \mathrm{g}$ de DON en harinas y subproductos de trigo, pero no se establecieron aún en granos de cebada o productos originados con dicho cereal (Centro de Información oficial, Normativas y avisos legales de Uruguay, 2006).

A nivel mundial, desde el 2011, existe un anteproyecto para revisar los niveles máximos de DON y establecer límites máximos para sus derivados acetilados en cereales y productos a base de cereales. El mismo fue revisado posteriormente con el fin de establecer límites máximos, métodos de muestreo y análisis de muestras. El Comité del Codex sobre Contaminantes en los Alimentos acordó reanudar el trabajo sobre los niveles máximos para DON y sus derivados acetilados en cereales y en productos a base de cereales, en vista de la existencia de suficientes datos sobre la presencia de estas toxinas (FAO/OMS, 2011).

Los límites para la contaminación por DON y/o NIV aún no se han establecido en ciertos países de América del Sur, como en Argentina. En nuestro país, actualmente existe un anteproyecto en el que se establecen como límites máximos $2 \mu \mathrm{g} / \mathrm{g}$ de $\mathrm{DON}$ en cereales, límites máximos $1 \mu \mathrm{g} / \mathrm{g}$ de $\mathrm{DON}$ en productos a base de cereales (harinas) y límite máximo $0,5 \mu \mathrm{g} / \mathrm{g}$ de DON en alimentos a base de cereales para lactantes y niños de corta edad (Comisión del Codex Alimentarius 2013). Por otro lado, en la reunión del Comité sobre Contaminantes de los Alimentos en marzo del 2015, se acordó revisar el anteproyecto del Código de prácticas para prevenir y reducir la contaminación de los cereales por micotoxinas creado en el 2003. En esta se propusieron prácticas recomendadas a partir de buenas prácticas agrícolas y buenas prácticas de 
fabricación. Algunas de ellas son:

- Educar a los productores en cuanto a los factores ambientales que favorecen la infección, la proliferación fúngica y la producción de toxinas en los cultivos de cereales en las explotaciones agrícolas.

- Las autoridades nacionales deben apoyar la investigación sobre métodos y técnicas para prevenir la contaminación fúngica en el campo y durante la cosecha y el almacenamiento de los cereales.

- Considerar la posibilidad de elaborar y mantener un plan de rotación de cultivos para evitar que se plante el mismo cultivo en el mismo campo en dos años consecutivos.

- $\quad$ Siempre que resulte posible y práctico, preparar el terreno para la siembra de cada nuevo cultivo destruyendo, eliminando o arando por debajo de las espigas antiguas, los tallos y otros rastrojos que puedan servir o haber servido de sustrato para el desarrollo de hongos productores de micotoxinas. En zonas vulnerables a la erosión quizás sea necesario aplicar prácticas que excluyan la labranza, en aras de la conservación del suelo.

- Siempre que resulte práctico se elegirá, para sembrar los cultivos, un momento que permita evitar altas temperaturas y tensión debida a la sequía durante el período de desarrollo y maduración de los granos.

- Reducir al mínimo los daños provocados por insectos y por infecciones fúngicas en las proximidades del cultivo, así como también los daños mecánicos a las plantas durante el cultivo.

- $\quad$ Programar la recolección de manera que el grano tenga un bajo 
contenido de humedad y esté en plena madurez.

- Los contenedores que vayan a utilizarse para recoger el grano y transportarlo del campo a las instalaciones de secado, y de éstas a los almacenes, deberán estar limpios, secos y exentos de insectos y proliferación fúngica.

- Evitar el apilamiento o amontonamiento de producto húmedo recién recolectado por un lapso superior a unas pocas horas antes del secado o la trilla.

- Documentar los procedimientos de recolección y almacenamiento utilizados en cada temporada tomando nota de las mediciones (por ejemplo, la temperatura y la humedad) y de cualquier desviación o cambios con respecto a las prácticas tradicionales.

- $\quad$ El Sistema de Análisis de Peligros y de Puntos Críticos de Control es un método de gestión de la inocuidad de los alimentos que se utiliza para identificar y controlar los peligros en el sistema de producción y elaboración.

\subsection{Interacciones entre Fusarium y hospedante}

En los agroecosistemas, se define como patosistema vegetal a la interacción entre un hospedante vegetal y un huésped que altera el funcionamiento del hospedante provocando una enfermedad. Esta interacción es estable siempre y cuando no sea modificada por el humano, debido a que los desequilibrios en la interacción son regulados por los mismos hospedantes y/o 
huéspedes.

Los estudios de interacción planta-patógeno generalmente se realizan en el hospedante específico del cual se aisló el agente patógeno, sin embargo, esto puede no ser práctico u óptimo en los casos en que el hospedante tenga un ciclo de vida largo, requiera gran espacio para su crecimiento y/o posea un genoma grande o complejo. En tales casos, las especies asignadas como "plantas modelo" pueden proporcionar una alternativa oportuna. Por ejemplo, Arabidopsis thaliana es el hospedante más utilizado con ventajas reconocidas que la hacen útil para el análisis molecular y genético (Dangl, 1993). En primer lugar, es un verdadero diploide con un ciclo de vida corto que va desde 6 semanas a 8 semanas bajo determinadas condiciones de cultivo. Su rápido crecimiento permite el análisis de un gran número de individuos en un mínimo espacio, por lo tanto, la consiguiente amplificación rápida de los genotipos útiles para posteriores estudios. Además, es de fecundación autógama y produce numerosas semillas que permanecen viables durante muchos años. En segundo lugar, su compacto genoma con relativamente pocas secuencias repetidas y un bajo contenido en ADN (aproximadamente $70 \mathrm{Mpb}$ por núcleo haploide, unas 25 veces el tamaño del genoma de Escherichia coli), la convierten en la planta superior de genoma más pequeño conocido. En tercer lugar, puede ser transformada por Agrobacterium tumefaciens y mediante el plásmido Ti es posible introducir genes de interés y mantenerlos de forma estable.

Existen trabajos relacionados a diversas especies patógenas de cereales 
de gran importancia que se han focalizado en la interacción Arabidopsis patógeno, siendo el estudio con Fusarium graminearum uno de ellos. En estos se comprobó la compatibilidad del sistema y se conocen sus vías de señalización. Hoy en día se cuenta con mutantes de Arabidopsis con reducida percepción del etileno, las cuales han evidenciado mayor susceptibilidad frente a $F$. graminearum demostrando de esta manera la participación de la vía del etileno en respuesta a este patógeno (Chen et al., 2006; 2009). Recientemente, se realizó la primera evaluación de fitohormonas de Arabidopsis thaliana en presencia de $F$. poae mediante el uso de mutantes de las vías de señalización del ácido salicílico, ácido jasmónico y etileno, en la cual se observaron síntomas en las hojas inoculadas que permiten demostrar la capacidad de F. poae para infectar y desarrollarse en las hojas de Arabidopsis (Dinolfo et al., 2017).

A pesar de los numerosos estudios realizados utilizando este modelo para investigar especies causantes de la fusariosis de la espiga, Arabidopsis thaliana no es un hospedante natural de especies de Fusarium (Urban et al., 2002; Dinolfo et al., 2017). En la última década, un miembro de la familia Poaceae (como lo es la cebada) conocida como Brachypodium distachyon ha sido propuesta como la especie de planta modelo para cereales de grano pequeño. Esta especie tiene varias características que hacen de esta una planta adecuada para los estudios de interacción planta-patógeno: pequeño tamaño, auto-fertilidad, requisitos de crecimiento simple, ciclo de vida corto (2-3 meses), un genoma relativamente pequeño en comparación con otras gramíneas (Draper et al., 2001) y, hace un tiempo, fue publicada la secuencia completa de la línea Bd21 (International 
Brachypodium Initiative (IBI) 2010). Por lo tanto, hay algunas características genéticas y fisiológicas compartidas entre las gramíneas que permiten la traducción de los hallazgos utilizando este modelo de planta a otros miembros de la familia (Vogel et al., 2010; Chochois et al., 2012; Schneebeli et al., 2015). Se ha demostrado que $B$. distachyon es una especie hospedante para muchos patógenos de cereales como Claviceps purpurea, Rhizoctonia solani, Oculimacula spp., Ramularia collo-cygni y Cochliobolus sativus, entre otros (Peraldi et al., 2014; Schneebeli et al., 2015; Zhong et al., 2015; Kind et al., 2018). Con respecto a Fusarium, varios informes han demostrado que F. graminearum desarrolla síntomas típicos de la fusariosis de la espiga en B. distachyon y se propone el uso potencial de esta planta modelo para estudiar la interacción (Peraldi et al., 2011; Pasquet et al., 2014; Blümke et al., 2015). Por otro lado, ciertas características de los cultivos, como el trigo y la cebada, en relación a su tamaño genómico, su ciclo biológico, tamaño de planta, etc., hacen necesaria la búsqueda de sistemas compatibles de interacción planta-patógeno, que faciliten y puedan ser extrapolables a estos. Por ello, el empleo de la gramínea $B$. distachyon, como modelo reciente, hace posible plantear nuevos sistemas de estudio que permitan profundizar en el conocimiento de ciertas interacciones, en menor tiempo y que a futuro, puedan ser utilizadas en estudios comparativos, en búsqueda de características/genes que luego puedan ser aplicados a los cultivos.

A lo largo de los años, varios investigadores han evaluado la interacción de diferentes especies de Fusarium como un aspecto fundamental para comprender la interacción entre el hospedante y el patógeno. Para ello 
emplearon el uso de diferentes tejidos vegetales con el objetivo de encontrar un método rápido, confiable y eficiente para los ensayos de agresividad. Sin embargo, hasta la fecha, pocos estudios se han centrado en evaluar la interacción de las especies de Fusarium utilizando Brachypodium como modelo vegetal.

Debido a los efectos sobre la salud y las pérdidas económicas ocasionadas por la presencia de Fusarium se considera fundamental estudiar la diversidad de especies de este género en cereales de importancia como la cebada y la presencia de micotoxinas en sus granos. Así como también evaluar la interacción de las especies más recurrentes y/o toxigénicas obtenidas de los granos de cebada, en plantas modelo que permitan relacionar los efectos sobre gramíneas de interés agroalimenticios, utilizando un sistema rápido, económico y sencillo.

\subsection{Hipótesis de trabajo}

"La población de Fusarium es heterogénea a nivel de especie y por lo tanto en su potencial y producción de toxinas en los granos de cebada"

“Diferentes ecotipos de la planta modelo Brachypodium distachyon interactúan de diferente manera con distintas especies de Fusarium y entre distintos aislamientos de una misma especie" 


\subsection{Objetivos}

\subsubsection{Objetivo general}

El objetivo general de esta tesis es aportar conocimientos sobre uno de los géneros de patógenos fúngicos de interés agro-alimenticio más importante como generador de mermas en el rendimiento y como productor de toxinas nocivas para la salud humana y animal, en uno de los cultivos de invierno con mayor crecimiento de los últimos años.

\subsubsection{Objetivos específicos}

- Identificar las especies de Fusarium presentes en granos de cebada.

- Determinar la potencial producción de toxinas de las especies de Fusarium mayormente aisladas de los granos de cebada.

- Cuantificar las toxinas más importantes presentes y producidas por las especies de Fusarium más aisladas en granos de cebada.

- Realizar estudios de interacción entre Fusarium spp. con la nueva especie modelo gramínea Brachypodium distachyon. 


\section{CAPÍTULO II:}

Materiales y Métodos 


\section{1. Obtención de las muestras de cebada a analizar}

Las muestras utilizadas en este estudio se recopilaron a partir de muestreos realizados durante tres años $(2012,2013,2014)$ en las principales zonas productoras de cebada de nuestro país. Muchas de estas muestras fueron recibidas a través de la Red Nacional de Cebada Cervecera. Esta Red es una actividad público-privada coordinada por el grupo de trabajo del INTA Bordenave y que está enmarcada en un convenio de asistencia técnica entre INTA Argentina y empresas que conforman la Cámara de la Industria Cervecera. Además, se recibieron muestras enviadas por distintos productores de la zona. Las 24 localidades muestreadas fueron: Ayacucho, Azul, Balcarce, Bordenave, Coronel Pringles, Coronel Suarez, Daireaux, Dorrego, General La Madrid, Guaminí, Lobería, Miramar, Necochea, Olavarría, Quequén, Saavedra, San Carlos de Bolívar, San Cayetano, Tandil, Trenque Lauquen, Tres Arroyos, 9 de Julio (Provincia de Buenos Aires), Paraná (Provincia de Entre Ríos) y Oliveros (Provincia de Santa Fe) (Figura 11). Algunas de las muestras utilizadas para este ensayo contaban con el dato del genotipo a la que correspondían: Explorer, Scrabble, Shakira, Andreia, Qcarisma y Scarlett (Tabla 2, Capítulo 3).

Cada muestra constó de unos 2 kg de grano aproximadamente, los cuales se fraccionaron y redujeron a 200 g utilizando un divisor de granos "Cuarteador peine" Cerealtools ${ }^{\circledR}$. Estos fraccionamientos se almacenaron a $4{ }^{\circ} \mathrm{C}$ hasta su utilización para los distintos ensayos. 


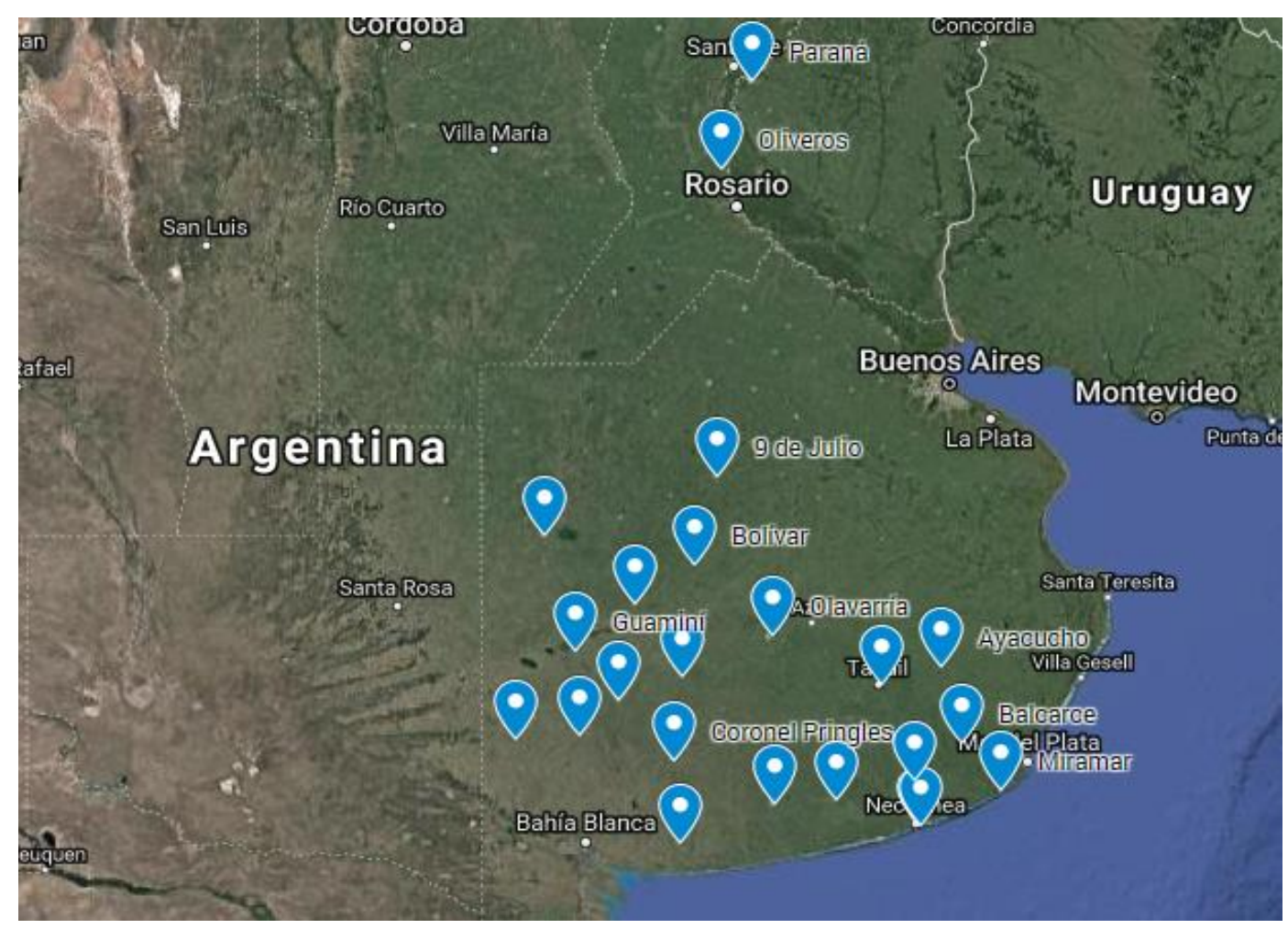

Figura 11. Distribución geográfica de las localidades muestreadas.

\section{2. Caracterización de especies de Fusarium}

\subsubsection{Aislamiento}

Para aislar las especies de Fusarium presentes en las muestras de cebada se desinfectaron $10 \mathrm{~g}$ de granos superficialmente. Para ello, se realizaron dos lavados consecutivos con etanol al $70 \%$ durante 2 min y dos lavados con hipoclorito de sodio al $5 \%$ durante el mismo tiempo. Se lavaron con agua destilada estéril y se colocaron 200 granos de cada muestra en placas de Petri (9 
$\mathrm{cm}$ de diámetro) con Agar Papa Glucosado $2 \%$ (APG) con cloranfenicol (0,25 g/l) (10 granos por placa, 20 placas por muestra) (Figura 12a). La manipulación de los granos se realizó bajo flujo laminar, con mechero encendido y con pinzas estériles, teniendo en cuentas medidas de seguridad y esterilidad necesarias. Las placas se incubaron en cámara de crecimiento a $25{ }^{\circ} \mathrm{C}$ por 5-7 días, con alternancia de $12 \mathrm{~h}$ luz/oscuridad (Leslie \& Summerell, 2006). Cuando se observó suficiente crecimiento fúngico sobre los granos de cebada incubados, se eligieron los potenciales aislamientos de Fusarium y repicaron en tubos de APG pico de flauta y en placas de Petri con medio Agar Agua Clavel (CLA) para su posterior identificación morfológica (Figura 12b). La selección y la elaboración de los medios de cultivo se tuvo en cuenta lo descripto por Leslie \& Summerell (2006).

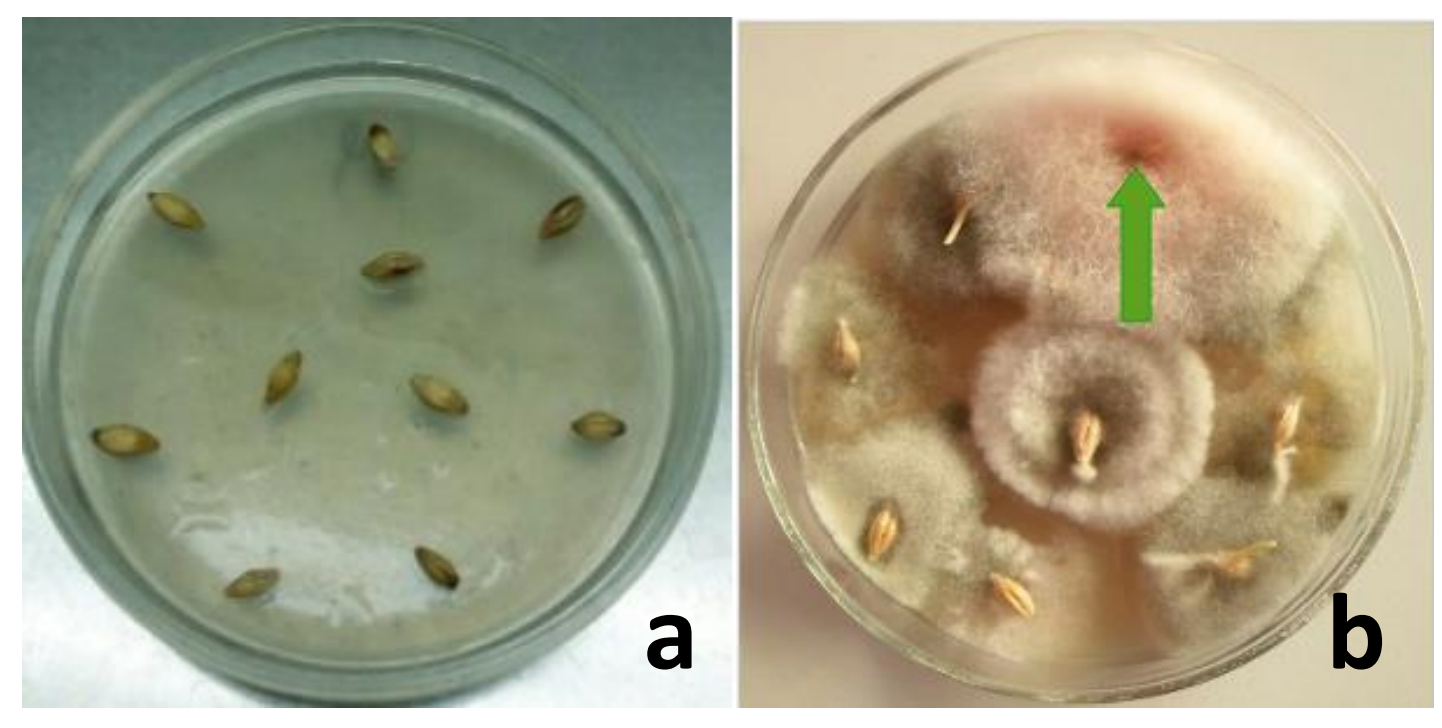

Figura 12. Placas de APG incubadas con granos de cebada (a-momento inicial y b- después de 5-7 días) con diversos hongos desarrollados. La flecha en verde señala un potencial aislamiento de Fusarium. 


\subsubsection{Identificación morfológica}

Cada aislamiento se idenfiticó morfológicamente mediante observaciones microscópicas del micelio crecido sobre el medio CLA (Figura 13a) y la evaluación de los tubos de APG pico de flauta de cada uno (Fugura 13b), como recomienda Leslie \& Summerell (2006). Las placas fueron inoculadas con cada aislamiento e incubadas durante 7-10 días en cámara de cultivo, con las condiciones de cultivo anteriormente descriptas. Una vez que se corroboró el crecimiento fúngico (crecimiento miceliar y estructuras visibles) se realizaron las observaciones microscópicas en microscopio óptico binocular (M/O) OLYMPUS CX31.
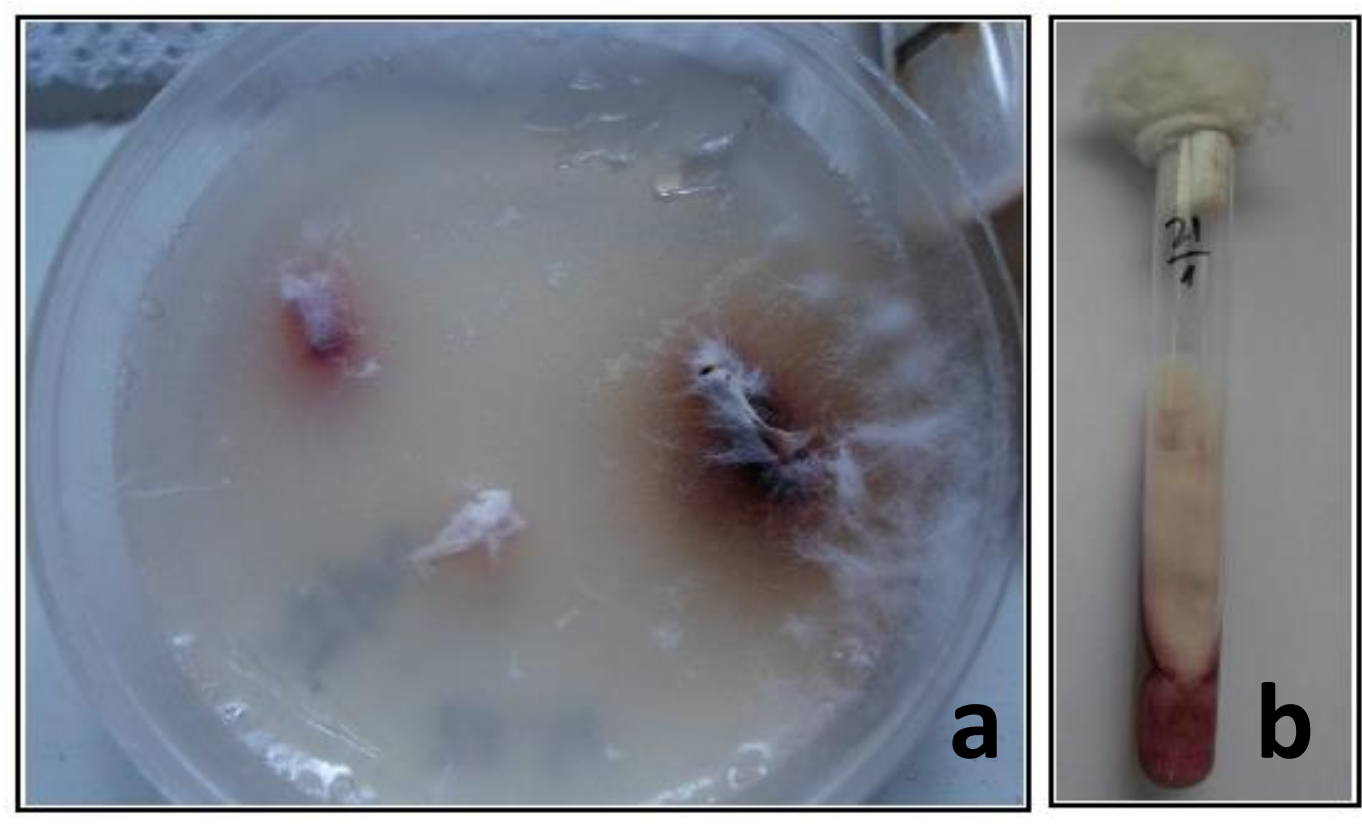

Figura 13. Placa con CLA (a) y tubo con APG pico de flauta (b) con Fusarium poae de 10 días de crecimiento.

Los aislamientos identificados dentro del género Fusarium fueron 
conservados en heladera a $4{ }^{\circ} \mathrm{C}$ en tubos de Spezieller Nährstoffarmer Agar (SNA) pico de flauta. Se utilizó este medio de cultivo debido a su capacidad para evitar mutaciones en las cepas fúngicas, conservando el material genético original.

\subsubsection{Identificación molecular}

\subsubsection{Extracción del ADN}

Una vez identificado morfológicamente cada aislamiento, se seleccionó al azar el $10 \%$ de los representantes de cada especie para corroborar molecularmente su identificación. Para eso, se repicó cada aislamiento monospórico en una placa de APG con antibiótico para evitar contaminaciones, se incubó por 5 días a $25^{\circ} \mathrm{C}$ con alternancia de $12 \mathrm{~h}$ luz/oscuridad y se extrajo el ADN fúngico del micelio producido. Para la extracción se utilizó el protocolo CTAB (cetil-trimetil-bromuro de amonio) (Doyle \& Doyle, 1990) modificado por Stenglein \& Balatti (2006). En principio, se preparó el "buffer CTAB" (100 mM Tris- $\mathrm{HCl}+20 \mathrm{mM}$ EDTA $+1,4 \mathrm{M} \mathrm{NaCl}+0,2 \% \beta$-mercaptoetanol). Luego de la incubación de los aislamientos, se raspó con una espátula el micelio formado y se colocó en un mortero estéril con nitrógeno líquido para su trituración. Cuando el micelio estuvo totalmente molido, se agregó $800 \mu \mathrm{l}$ de "buffer CTAB" $+200 \mu \mathrm{l}$ de CTAB al $10 \%+1 \%$ polivinil-pirrolidona (PVP) y se trituró nuevamente hasta su homogenización. La suspensión se colocó en tubos Eppendorf de $2 \mathrm{ml}$ previamente autoclavados y se incubaron por $30 \mathrm{~min}$ en un termobloque seco 
precalentado y estabilizado a $60^{\circ} \mathrm{C}$. Luego de ese período, se enrazaron los tubos con cloroformo isoamilalcohol (12:1) para su primer lavado. Se mezclaron las fases y se centrifugó a $14.000 \mathrm{rpm}$ por $5 \mathrm{~min}$. Una vez identificada la fase acuosa y traspasada a un nuevo tubo Eppendorf de $2 \mathrm{ml}$, se precipitó el ADN presente con isopropanol frio por $24 \mathrm{~h}$ a $-20{ }^{\circ} \mathrm{C}$. Al día siguiente, se centrifugaron los tubos por 10 min a máxima potencia (14.000 rpm) obteniéndose un pellet que fue lavado en primera instancia con etanol $70 \%$ - acetato de amonio $10 \mathrm{mM}$ y en segunda instancia con etanol $70 \%$ a $4{ }^{\circ} \mathrm{C}$. Luego de estos lavados, se dejó secar el pellet y, cuando se encontró libre de etanol, se resuspendió en buffer TE (10 mM Tris- $\mathrm{HCl}$ pH $8+1 \mathrm{mM}$ EDTA pH 8). La calidad del ADN obtenido de cada aislamiento se corroboró mediante corridas electroforéticas $(1 \times$ buffer Trisborato-EDTA) de aproximadamente $2 \mathrm{~h}$ a 80 voltios en geles de agarosa al 0,7 \% teñidos con $3 \mu$ l de GelREd TM (Biotium, Hayward, CA, USA), se observaron por irradiación con luz UV, se cuantificaron y se conservaron en frío para evitar la degradación del ADN.

Para la elaboración de cada solución stock se siguieron las recomendaciones del manual "Molecular cloning; a laboratory manual" (Sambrook et al., 1989).

\subsubsection{Reacciones en cadena de la polimerasa}

La identificación molecular de cada aislamiento se llevó a cabo mediante reacciones de PCR con cebadores especie-específicos. Para todas las reacciones, 
se utilizaron $1 \mu \mathrm{l}$ de la suspensión de cada ADN extraído (10-20 ng de ADN) en un volumen final de $25 \mu \mathrm{l}$ de reacción. Esta solución de reacción se preparó de la siguiente manera: $10 \mathrm{X}$ de buffer de reacción (20 mM Tris- $\mathrm{HCl} \mathrm{pH} 8,100 \mathrm{mM} \mathrm{KCl}$, 0,1 mM EDTA, 1 mM DTT, 50 \% glicerol, 0,5\% Tween $20 \circledR$ y 0,5 \% Nonidet P40®), 2,5 mM MgCl $2,1 \mu \mathrm{M}$ de cada cebador, $30 \mu \mathrm{M}$ de dNTP (Inbio-Highway, Tandil, Argentina), 1 U de Taq ADN polimerasa (Inbio-Highway, Tandil, Argentina), 0,014 \% de solución de Cresol Red (Sigma-Aldrich Co. St Louis, MO), 0,0005 \% Tween $20 \AA, 0,0005 \%$ Nonidet $P 40 \AA$ y agua destilada estéril hasta completar volumen final. Las amplificaciones se realizaron en un termociclador XP (Bioer Technology Co.) y los programas utilizados fueron los sugeridos por cada autor (Tabla 1).

Tabla 1. Pares de cebadores especie-específicos utilizados para la identificación molecular de las distintas especies de Fusarium aisladas.

\begin{tabular}{|c|c|c|c|c|}
\hline Especie & Cebadores & $\begin{array}{c}\text { Temperatura } \\
\text { de hibridación }\end{array}$ & $\begin{array}{c}\text { Amplificación } \\
\text { esperada } \\
\text { (pares de } \\
\text { bases, pb) }\end{array}$ & Cita bibliográfica \\
\hline F. poae & Fp82F/ Fp82R & $62{ }^{\circ} \mathrm{C}$ & $220 \mathrm{pb}$ & Parry et al. (1996) \\
\hline F. graminearum & $\begin{array}{l}\text { Fg16-gram-F/ } \\
\text { Fg16-gram-R }\end{array}$ & $62^{\circ} \mathrm{C}$ & $400-500 \mathrm{pb}$ & Nicholson et al. (1998) \\
\hline $\begin{array}{l}\text { F. pseudo- } \\
\text { graminearum }\end{array}$ & $\begin{array}{l}\text { FPG-pseudo-F/ } \\
\text { FPG-pseudo-R }\end{array}$ & $56-65^{\circ} \mathrm{C}$ & $779 \mathrm{pb}$ & Williams et al. (2002) \\
\hline F. tricinctum & $\begin{array}{l}\text { tri1-tricinctum/ } \\
\text { tri2-tricinctum }\end{array}$ & $65^{\circ} \mathrm{C}$ & $215 \mathrm{pb}$ & Kulik (2008) \\
\hline F. acuminarum & FAC-F/ FAC-R & $56-65^{\circ} \mathrm{C}$ & $602 \mathrm{pb}$ & Williams et al. (2002) \\
\hline F. proliferatum & PRO-F/ PRO-R & $56^{\circ} \mathrm{C}$ & $585 \mathrm{pb}$ & Mulé et al. (2004) \\
\hline F. cerealis & CRO-AF/ CRO-AR & $60^{\circ} \mathrm{C}$ & $842 \mathrm{pb}$ & Yoder et al. (1998) \\
\hline F. chlamydosporum & Fchla-F/ Fchla-R & $47^{\circ} \mathrm{C}$ & $300 \mathrm{pb}$ & Comunicación personal \\
\hline F. oxysporum & Foxy-F/ Foxy-R & $58^{\circ} \mathrm{C}$ & $340 \mathrm{pb}$ & Mishra et al. (2003) \\
\hline $\begin{array}{c}F . \text { incarnatum }-F . \\
\text { equiseti }\end{array}$ & Feq-F/ Feq-R & $66^{\circ} \mathrm{C}$ & $990 \mathrm{pb}$ & Jurado et al. (2005) \\
\hline
\end{tabular}


Los controles positivos utilizados para estas reacciones fueron ADN de especies previamente identificadas: Fusarium poae "I109" (Dinolfo et al., 2010), F. graminearum sensu stricto "Ass5" (Castañares et al., 2016) (desde ahora en adelante llamado "F. graminearum"), F. pseudograminearum "LPSC1154" (Castañares et al., 2012), F. tricinctum "Taz1a" (Castañares et al., 2011), F. acuminatum "HAMa1"(Galizio, 2010), F. proliferatum "Los pichones 3" (Stenglein et al., 2010), F. cerealis "Herrero5" (Castañares et al., 2013), F. chlamydosporum “14-2" (Silvestro, 2015), F. incarnatum- F. equiseti “12-15" (Silvestro, 2015) y F. oxysporum "19" (Silvestro, 2015). Los controles negativos fueron reacciones sin ADN y reacciones con ADN de otras especies. Cada producto de PCR se examinó por electroforesis en gel agarosa al 1,5\% con $3 \mu$ de GelRed ${ }^{\mathrm{TM}}$. El buffer de corrida, el tiempo y la visualización de los fragmentos se realizaron de igual manera que para evaluar la calidad del ADN. Se utilizó un estándar de peso molecular de ADN (100 pb) (Genbiotech S.R.L., Buenos Aires, Argentina) con un rango de fragmentos distinguibles de $100 \mathrm{pb}$ a $1500 \mathrm{pb}$, para identificar el tamaño de las amplificaciones. Los geles de agarosa fueron registrados con el sistema de documentación digital DOC-6490 (Biodynamics S.R.L., Buenos Aires, Argentina).

\subsubsection{Secuenciación del factor de elongación 1- $\alpha$}

Se realizó la secuenciación del factor de elongación 1- $\alpha$, que es un marcador filogenético recomendado para identificar y/o confirmar especies de 
Fusarium (Geiser et al., 2004). Se eligió al azar un representante de cada especie dentro del grupo de aislamientos identificados por PCR.

Las amplificaciones se realizaron de la misma forma que las reacciones anteriormente explicadas. El programa utilizado fue el propuesto por O'Donnell et al. (1998) una etapa de desnaturalización inicial a $95^{\circ} \mathrm{C}$ durante $2 \mathrm{~min}$, seguido de 30 ciclos a $95^{\circ} \mathrm{C}$ durante $30 \mathrm{seg}, 54{ }^{\circ} \mathrm{C}$ durante 35 seg y $72{ }^{\circ} \mathrm{C}$ durante $45 \mathrm{seg}$, y un ciclo de extensión final a $72{ }^{\circ} \mathrm{C}$ durante $2 \mathrm{~min}$. Se utilizaron los cebadores EF1(5'-ATGGGTAAGGARGACAAGAC-3')/EF2(5'-GGARGTACCAGTSATCATGTT-3') que amplifican fragmentos de $\approx 700 \mathrm{pb}$ (O'Donnell et al., 1998). Se confirmaron las amplificaciones de los fragmentos por electroforesis en gel de agarosa al 1,5\% con $3 \mu \mathrm{l}$ de GelRed ${ }^{\mathrm{TM}}$. El buffer de corrida, el tiempo y la visualización de los fragmentos se realizaron de la misma manera que para evaluar la calidad del ADN. Los fragmentos se purificaron utilizando el kit 'Purelink ${ }^{T M} M$ Quick Gel Extraction and PCR Purification Combo Kit' (Invitrogen, Buenos Aires, Argentina), siguiendo el procedimiento sugerido en el manual del fabricante. Cada producto obtenido se cuantificó con un fluorómetro siguiendo las especificaciones del fabricante (Qubit ${ }^{\mathrm{TM}}$ fluorometer, Invitrogen, Buenos Aires, Argentina) y se envió purificado a secuenciar, en ambos sentidos, al servicio de secuenciación del Centro de Referencia de Lactobacilos (CERELA) - Conicet, Tucumán, Argentina.

Una vez recibidas las secuencias de los fragmentos, se editaron con el programa Bioedit 7.0 (Hall, 1999) y se compararon con la base de datos del Centro Nacional de Información Biotecnológica (NCBI) disponible en la página web (https://www.ncbi.nlm.nih.gov/) para confirmar su identificación utilizando 
BLASTN (Altschul et al., 1990).

\subsection{Micotoxinas}

\subsubsection{Potencial producción de toxinas}

Las especies de Fusarium más aisladas y con capacidad de producir tricotecenos, fueron F. graminearum y F. poae. Por lo tanto, se seleccionaron al azar aislamientos representantes de cada especie (hasta el $10 \%$ respecto al total de aislamientos de cada especie) para identificar a nivel genético la potencialidad de producir DON y NIV. Se realizaron reacciones de PCR utilizando cebadores específicos. El ADN de F. graminearum se amplificó con cebadores basados en el gen tri13 para la potencial producción de NIV y DON, Tri13NIVF(5'CCAAATCCGAAAACCGCAG-3')/Tri13NIVR(5'-TTGAAAGCTCCAATGTCGGGGGG-3'); Tri13DONF(5'-CATCATGAGACTTGTKCRAGTTTGGG-3')/Tri13DONR(5'GCTAGATCGATTGTTGCATTGAG-3') (Chandler et al., 2003). El ADN de F. poae se amplificó con cebadores diseñados a partir del gen tri7, nivPf(5'TATCCTTGCATGGCAATGCC-3')/nivPr(5'-AAATGGCGATACGAGTATTGA-3') para evaluar la capacidad genética de producir NIV (Dinolfo et al., 2012). Todas las reacciones se llevaron a cabo, como se describió anteriormente, utilizando $1 \mu \mathrm{l}$ de la suspensión de cada ADN extraído en un volumen final de $25 \mu$ l de reacción. Los programas utilizados para realizar las amplificaciones fueron los sugeridos por cada autor (Chandler et al., 2003; Dinolfo et al., 2012). Como controles 
positivos de cada reacción se utilizaron ADN de F. poae "I109" (Dinolfo et al., 2010) (productor de NIV) y F. graminearum "Ass4" (productor de DON), F. meridionale (productor de NIV), F. cortaderiae (productor de NIV), F. austroamericanum (productor de DON) (Castañares et al., 2016). Como control negativo se realizó una reacción sin ADN. Se corrieron y visualizaron las amplificaciones como se describió anteriormente para las reacciones de PCR, junto con un estándar de peso molecular de ADN (100 pb). Se analizaron los fragmentos de las amplificaciones obtenidas de $\approx 282 \mathrm{pb}$ y $\approx 296 \mathrm{pb}$, las cuales son características de genotipos DON ( $F$ graminearum) y NIV ( $F$ poae), respectivamente.

\subsubsection{Determinación de micotoxinas}

La determinación de potencial producción de toxinas demostró que los aislamientos de F. graminearum eran capaces de producir DON y los aislamientos de F. poae eran capaces de producir NIV. Teniendo en cuenta estos resultados y la importancia de la toxicidad de estos compuestos, se realizó la determinación de las mismas en todas las muestras de cebada analizadas.

Las semillas (50 g) se molieron en un homogeneizador de cuchillas. Se extrajo una alícuota de $12,5 \mathrm{~g}$ de cada harina con $50 \mathrm{ml}$ de acetonitrilo: agua 86:16 (v/v) y se agitó en un agitador orbital durante 20 minutos. El sobrenadante se filtró con un papel de filtro $\mathrm{N}^{\circ} 101$. Para la limpieza, $8 \mathrm{ml}$ de la suspensión se pasaron a través de una columna Myco Sep Trich $+{ }^{\circledR}$ y $4 \mathrm{ml}$ del 
filtrado se evaporaron a sequedad bajo un flujo de nitrógeno a $60{ }^{\circ} \mathrm{C}$ en una máquina para evaporar solventes Turbo Vap L (Caliper Life Sciences, Waltham, MA, Estados Unidos).

Los extractos resultantes se resuspendieron en $500 \mu \mathrm{l}$ de la fase móvil y se pasaron por un filtro de microcelulosa de 0,22 $\mu \mathrm{m}$ antes de la inyección en el sistema HPLC-UV/V. El análisis se llevó a cabo con un sistema de bomba de gradiente de HPLC Gilson equipado con un detector de 151 UV/V. La columna utilizada fue una Hydro RP Phenomenex $250 \mathrm{~mm}$ de $3 \mathrm{~mm}$; 4- $\mu \mathrm{m}$. La fase móvil fue acetonitrilo: agua 20:80 corriendo en modo isocrático a $1 \mathrm{ml} / \mathrm{min}$. Los picos de DON y NIV se detectaron a $222 \mathrm{~nm}$ y la cuantificación se realizó utilizando estándares externos. El rango lineal estuvo entre 0,156 y 2,5 g/g, siendo de 0,156 g/g el límite de cuantificación. Las muestras por encima del rango lineal se diluyeron y se volvieron a analizar para ajustar los valores de la curva de calibración. Se utilizaron los criterios de los umbrales de DON establecidos por la Comisión Europea para la evaluación de los resultados.

\subsection{Datos climáticos}

Teniendo en cuenta la importancia de las condiciones ambientales durante el desarrollo del cultivo de cebada en relación a la susceptibilidad a Fusarium, se analizaron los datos climáticos durante los tres años muestreados, en particular, durante la etapa de floración.

De cada año muestreado, se analizaron datos de precipitación, 
temperatura y humedad relativa del 15 de octubre al 15 de noviembre de localidades representativas del muestreo (Azul, Balcarce, Bordenave, Miramar, Necochea y Paraná) (Figura 14). Se copilaron los datos del Centro Meteorológico Nacional. En general, se registró un régimen normal de precipitaciones en las diferentes localidades, con la excepción de un dato registrado en Bordenave durante el 2014, donde se observó una precipitación de $182 \mathrm{~mm}$ en un solo día (26 de octubre).

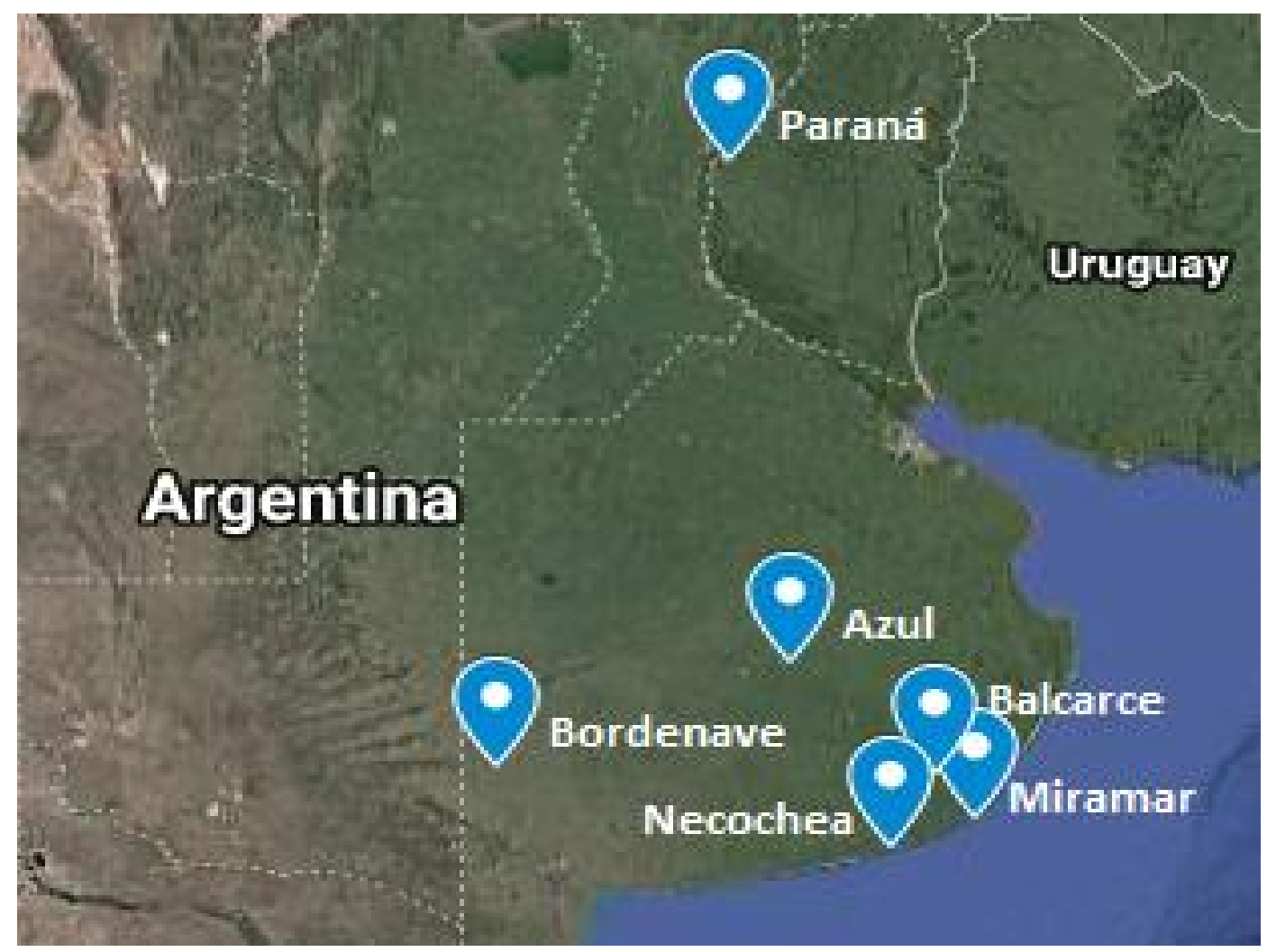

Figura 14. Distribución del origen de los datos climáticos recopilados.

\subsection{Análisis estadístico}

Considerando los resultados de especies de Fusarium aisladas, se decidió 
focalizar el análisis estadístico en las dos especies mayormente aisladas, $F$. graminearum y F. poae. La frecuencia de estas especies de Fusarium y las concentraciones de toxinas se analizaron mediante el coeficiente de correlación de Pearson con respecto a la asociación entre las concentraciones de toxinas y el porcentaje de F. graminearum y/o F. poae identificado en las muestras de cebada. Todos los análisis estadísticos se realizaron con el software InfoStat (versión 2016, grupo InfoStat UNC, Córdoba, Argentina, 2008).

\subsection{Fusarium / Brachypodium distachyon}

\subsubsection{Obtención y selección de los ecotipos de Brachypodium distachyon}

En los últimos años, Brachypodium distachyon se ha considerado como una herramienta poderosa para la genómica comparativa entre gramíneas debido a sus características atractivas como sistema. $B$. distachyon $(B d)$ tiene un tamaño pequeño (20 cm aproximadamente) y un ciclo de vida rápido (8 a 10 semanas). El ecotipo $\mathrm{Bd} 21$ tiene un pequeño genoma diploide totalmente secuenciado (272 Mbp) (International Brachypodium Initiative 2010). Es por esto que, en parte y para este ensayo, se realizó la inoculación de raíces de $B d$ mediante la técnica de slurry (se describe a continuación) con las especies de Fusarium aisladas de las muestras, que se consideraron más importantes a nivel agronómico y toxicológico.

Se utilizaron 6 ecotipos de $B d$ de diferentes orígenes (Afganistán, Irán, 
Israel, Pakistán, Sudáfrica y Uruguay) y el genotipo diploide Bd 21 (genoma secuenciado y publicado) para el ensayo de interacción. Se optó por utilizar los ecotipos provenientes de países representativos de distintas zonas geográficas (dentro de las líneas obtenidas y cedidas por la Universidad Estatal de Washington) (Figura 15).

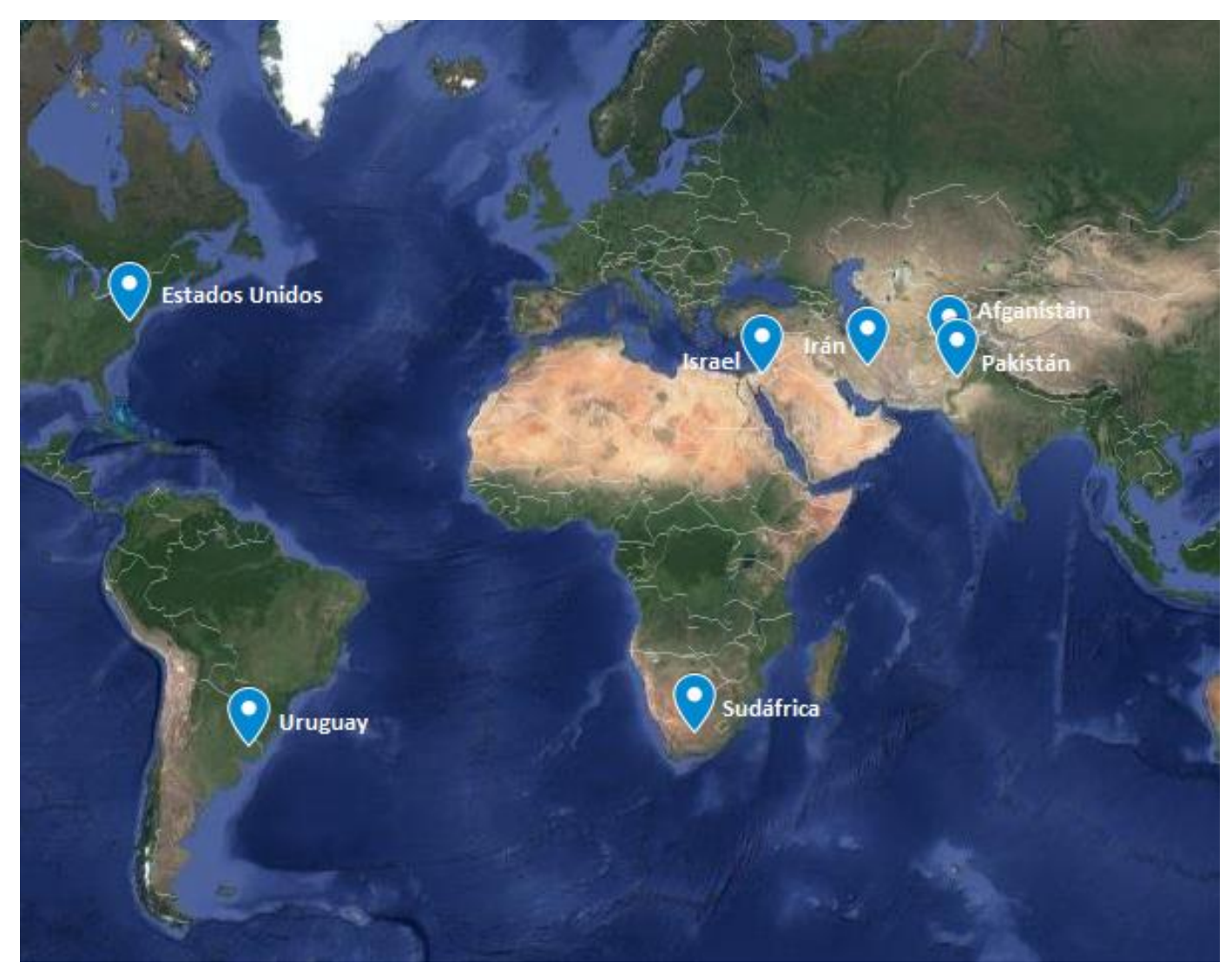

Figura 15. Distribución geográfica de ecotipos de Brachypodium distachyon utilizados para el ensayo de interacción.

\subsubsection{Selección de los aislamientos a inocular}

A partir de los resultados de especies presentes en los granos de cebada, se seleccionaron las de mayor impacto agronómico y toxicológico, como se 
mencionó anteriormente. Fusarium graminearum y F. poae fueron las especies más aisladas, ambas con potencial producción de toxinas importantes para la salud humana/animal, DON y NIV, respectivamente. Además, se aislaron dos especies importantes a nivel agronómico y con capacidad de producir toxinas, como son F. pseudograminearum (DON) y F. cerealis (NIV). Con la finalidad de comparar la agresividad entre especies y entre aislamientos de una misma especie, se eligieron al azar 3 aislamientos de F. graminearum (107-18 FG, 34-15 FG, 102-43 FG), 3 aislamientos de F. poae (8-1 FP, 9-5 FP, 25-5 FP), 2 aislamientos de F. pseudograminearum (16-2 FPS, 106-35 FPS) y 2 aislamientos de $F$. cerealis (105-41 FC, 112-10 FC). La nomenclatura de los aislamientos corresponde al número de "muestra analizada-aislamiento obtenido" (por ejemplo: 107-18 corresponde al aislamiento 18 obtenido de la muestra 107). Los aislamientos fueron obtenidos a partir de diferentes muestras recolectadas durante los tres años de muestreo y oriundas de 7 localidades distintas. Estos ya se encontraban identificados morfológica y molecularmente.

\subsubsection{Ensayo de interacción}

\subsubsection{Preparado de inóculo}

Se prepararon 16 placas de Petri con APG y antibiótico con cada aislamiento y se incubaron por 7 días en cámara de crecimiento a $25^{\circ} \mathrm{C}$ con alternancia de $12 \mathrm{~h}$ luz/oscuridad (Leslie \& Summerell, 2006). Una vez crecido el 
micelio, se rasparon las 16 placas de cada aislamiento con una espátula estéril, bajo flujo laminar y se trituraron con 8 placas de Agar Agua para lograr el slurry (Figura 16). Inmediatamente después de su procesado, se conservó a $4{ }^{\circ} \mathrm{C}$ hasta el momento de la inoculación. Entre la elaboración del slurry de cada aislamiento, se desinfectó el material utilizado con sucesivos lavados con Etanol $70 \%$ durante 2 min y enjuagues con agua destilada estéril.

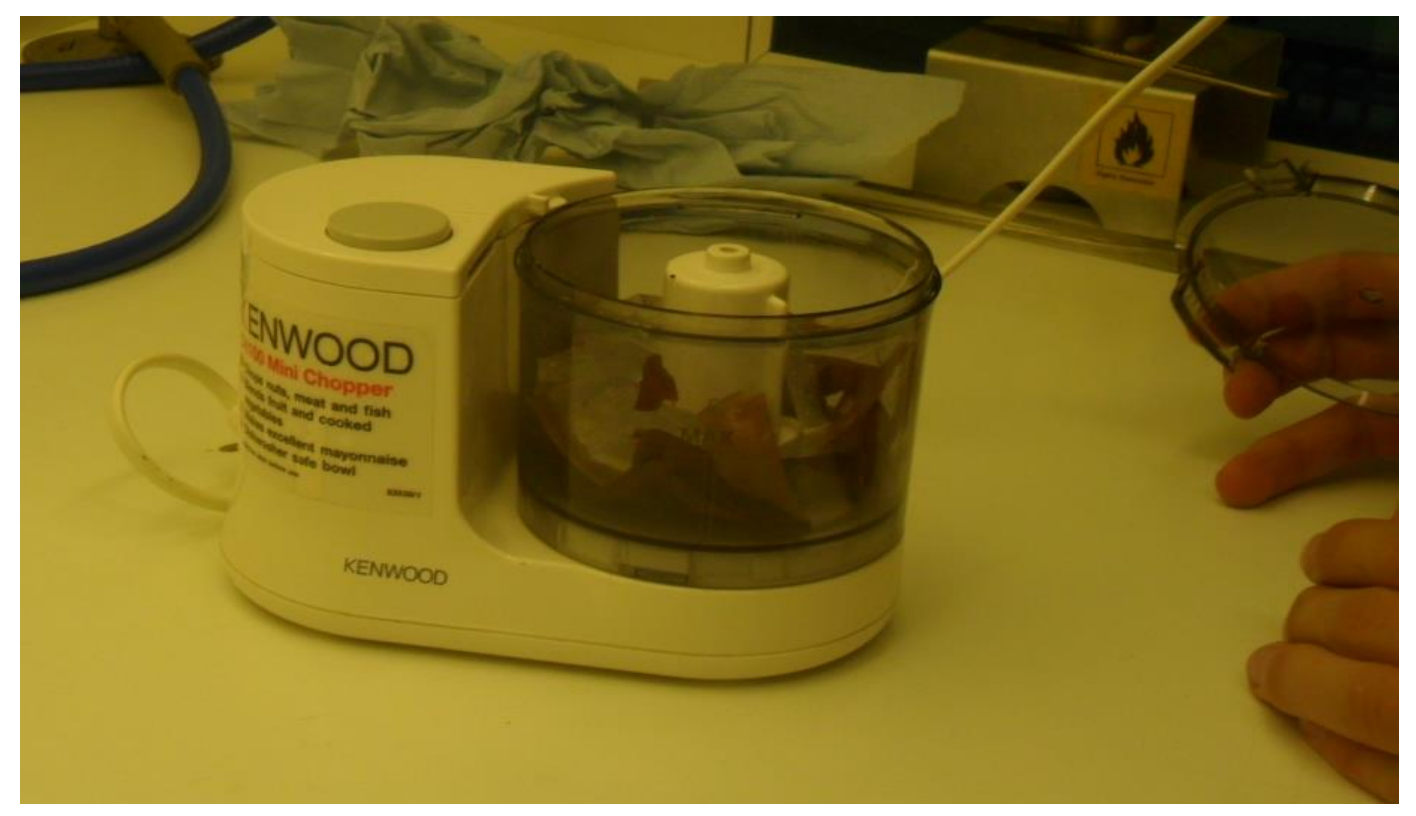

Figura 16. Procesado del micelio y el Agar Agua para la producción del slurry.

\subsubsection{Acondicionamiento de semillas y ensayo}

Inicialmente se multiplicaron las semillas de los distintos ecotipos (Figura 17 a y b) de manera controlada en invernáculo. Las semillas fueron cosechadas manualmente y almacenadas hasta su uso. Una vez que se contaba con la cantidad suficiente de semillas, se sacaron las cáscaras (tegumento 
externo) de 100 semillas de cada ecotipo, se desinfectaron con Etanol $70 \%$ (durante $2 \mathrm{~min}$ ), posteriormente con Hipoclorito de Sodio $1 \%$ (durante $2 \mathrm{~min}$ ) y finalmente se lavaron dos veces durante 2 min con agua destilada estéril.

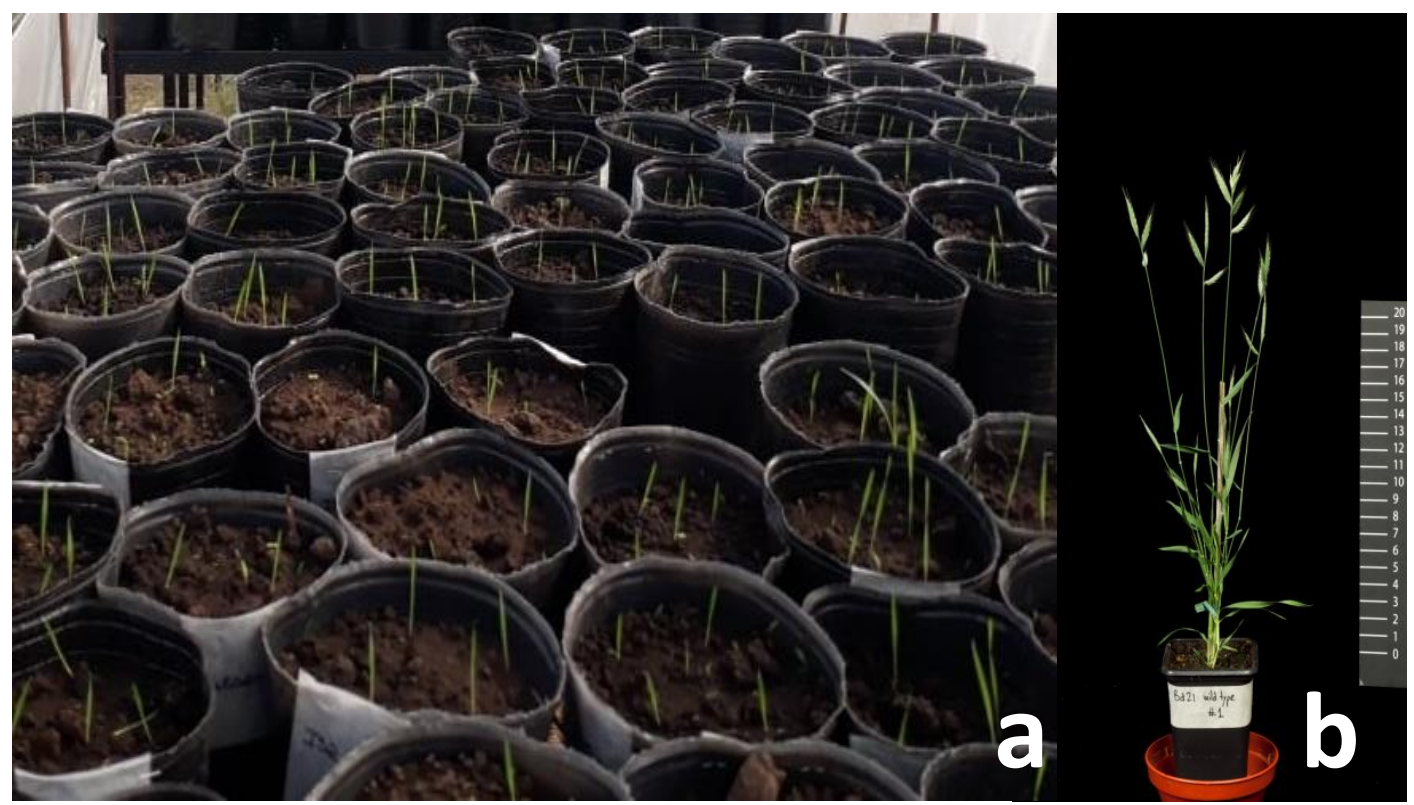

Figura 17. a - Multiplicación de semillas, b-ejemplar de Brachypodium.

Se prepararon placas rectangulares con Agar Agua al 0,8 \% (Figura 18) y papel de filtro estéril humedecido con agua destilada estéril. La función de esta capa de papel es que las raíces no desarrollen dentro del agar. Se colocaron 10 semillas por placa en la parte superior de la misma para dar lugar al crecimiento radicular (Figura 19). Se taparon con otro papel de filtro humedecido para favorecer el proceso de vernalización. Las placas se sellaron con Parafilm, se recubrieron con papel metálico (para generar oscuridad) y se colocaron a $4{ }^{\circ} \mathrm{C}$. Luego de 5 días, se extrajo el papel metálico y se descubrieron las semillas retirando el papel de filtro que las cubría (Figura 20). Luego se colocaron las 
placas en posición vertical en una cámara de crecimiento bajo condiciones de $16 / 8 \mathrm{~h}$ de luz/oscuridad a $22{ }^{\circ} \mathrm{C}$ durante los días necesarios para el crecimiento de las raíces a una longitud media considerable hasta la inoculación (aproximadamente 10 días) (Figura 21).

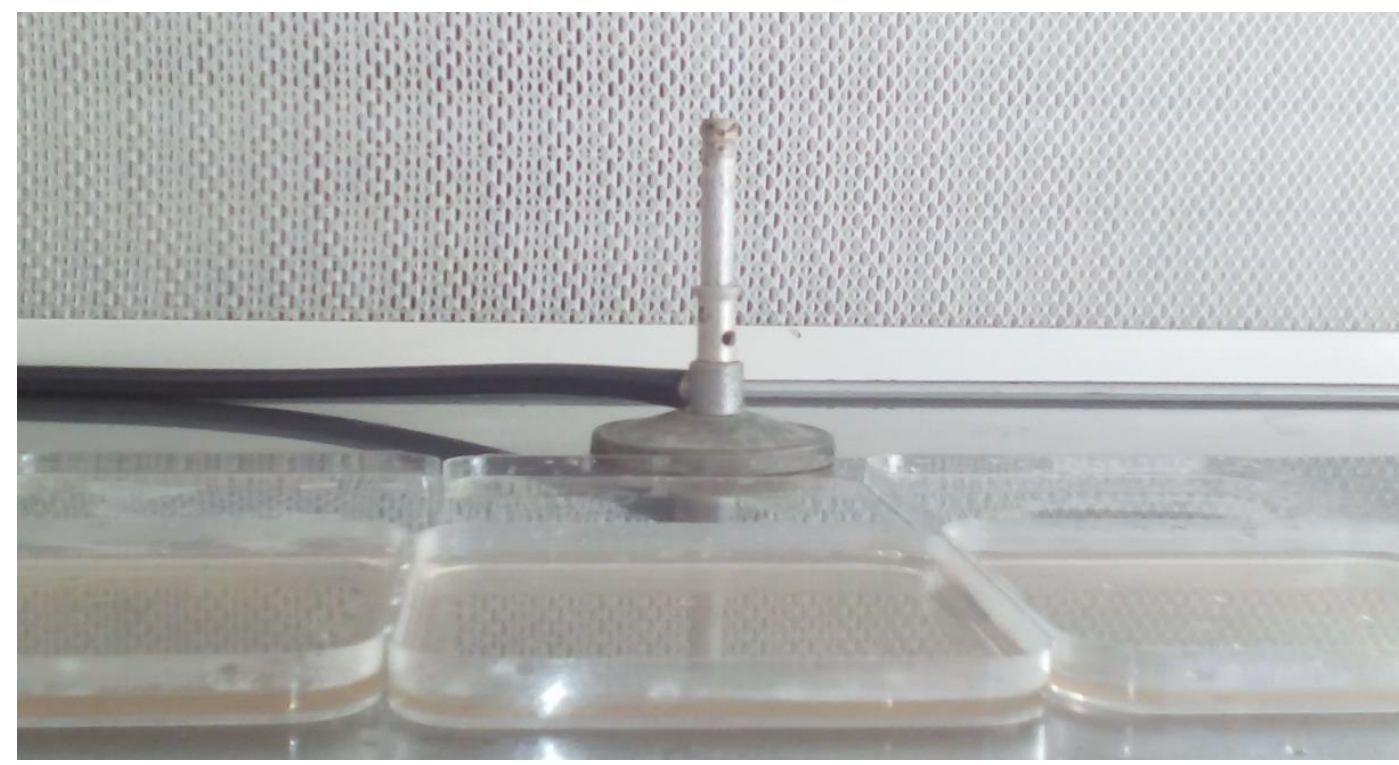

Figura 18. Preparado de las placas.

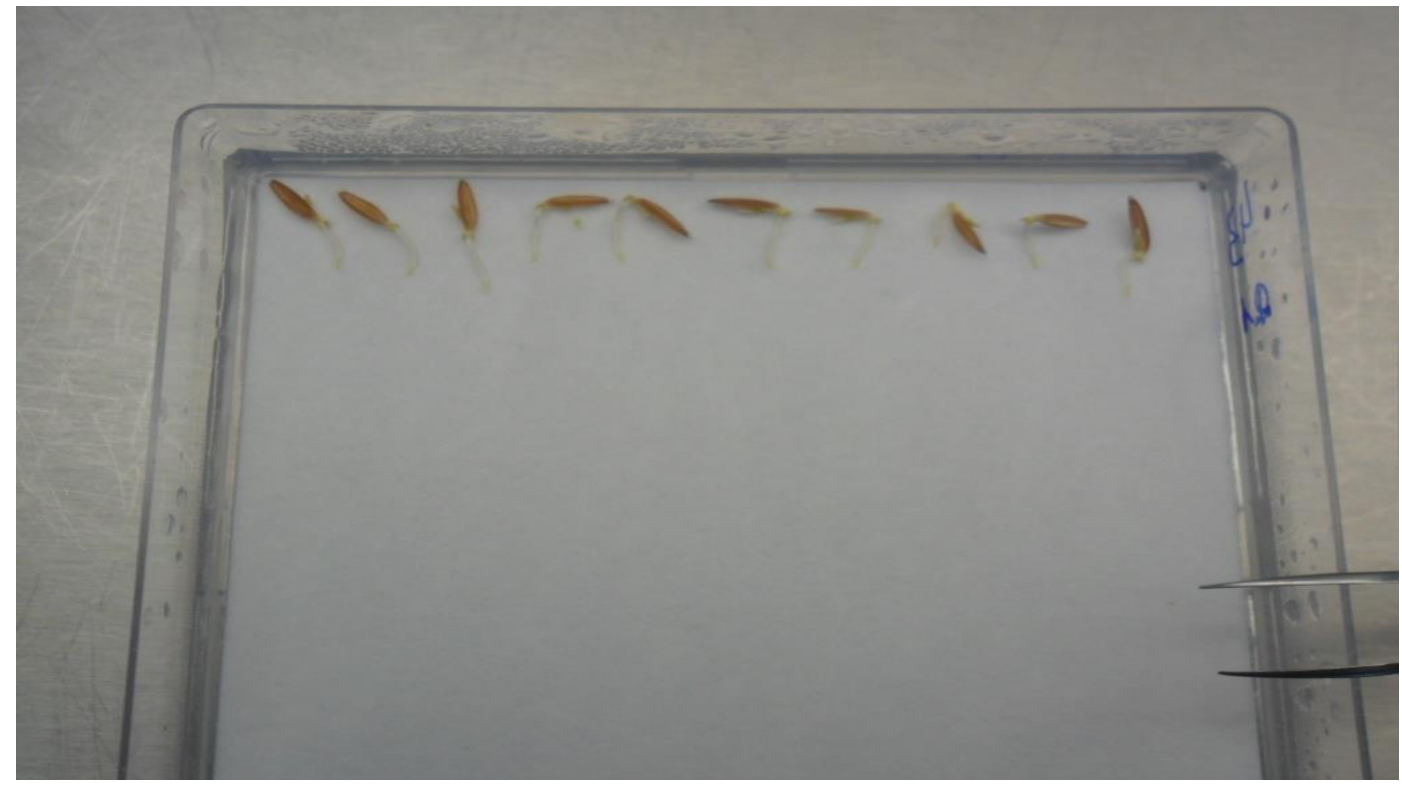

Figura 19. Siembra de semillas sobre placas con papel de filtro. 


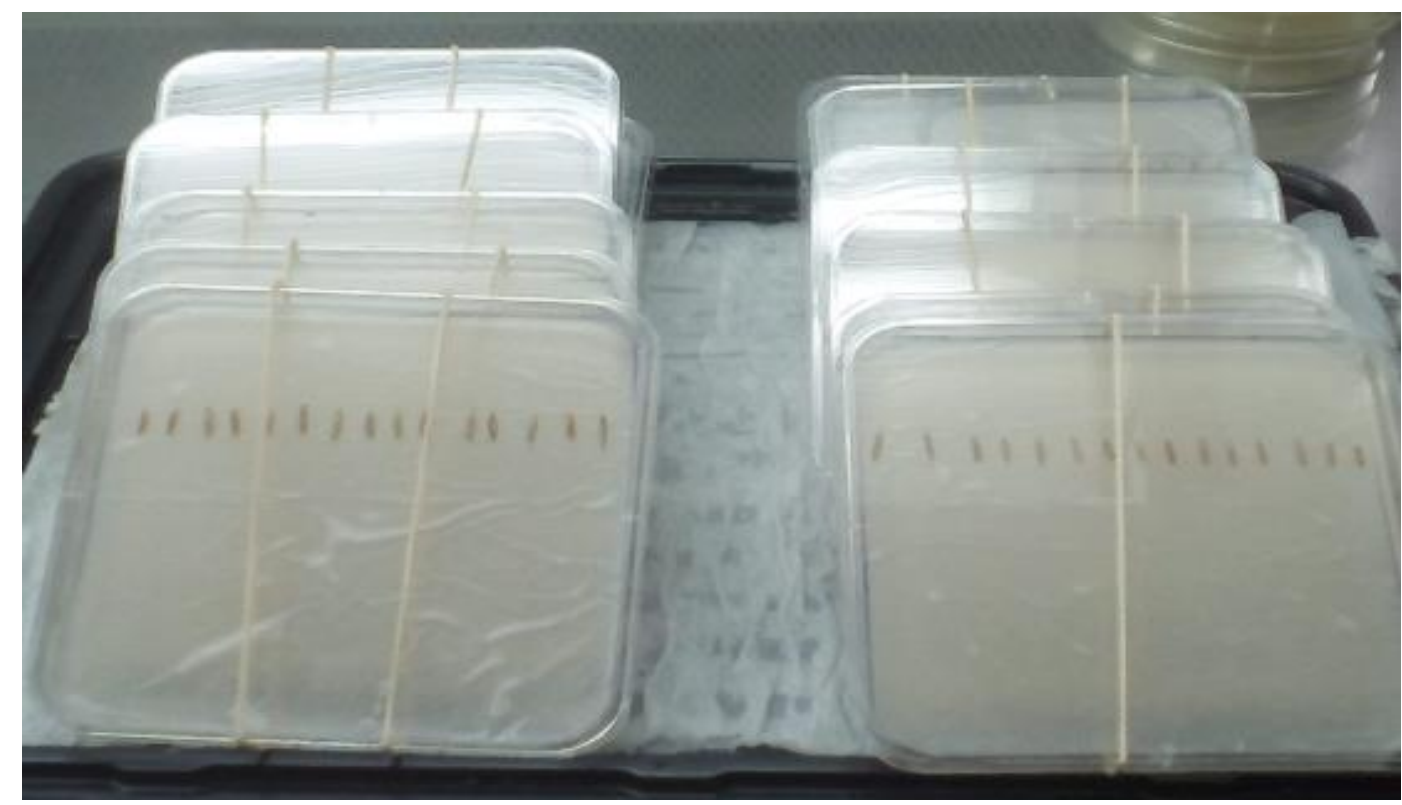

Figura 20. Pasaje de semillas de Brachypodium distachyon de $4^{\circ} \mathrm{C}$ a cámara de crecimiento.

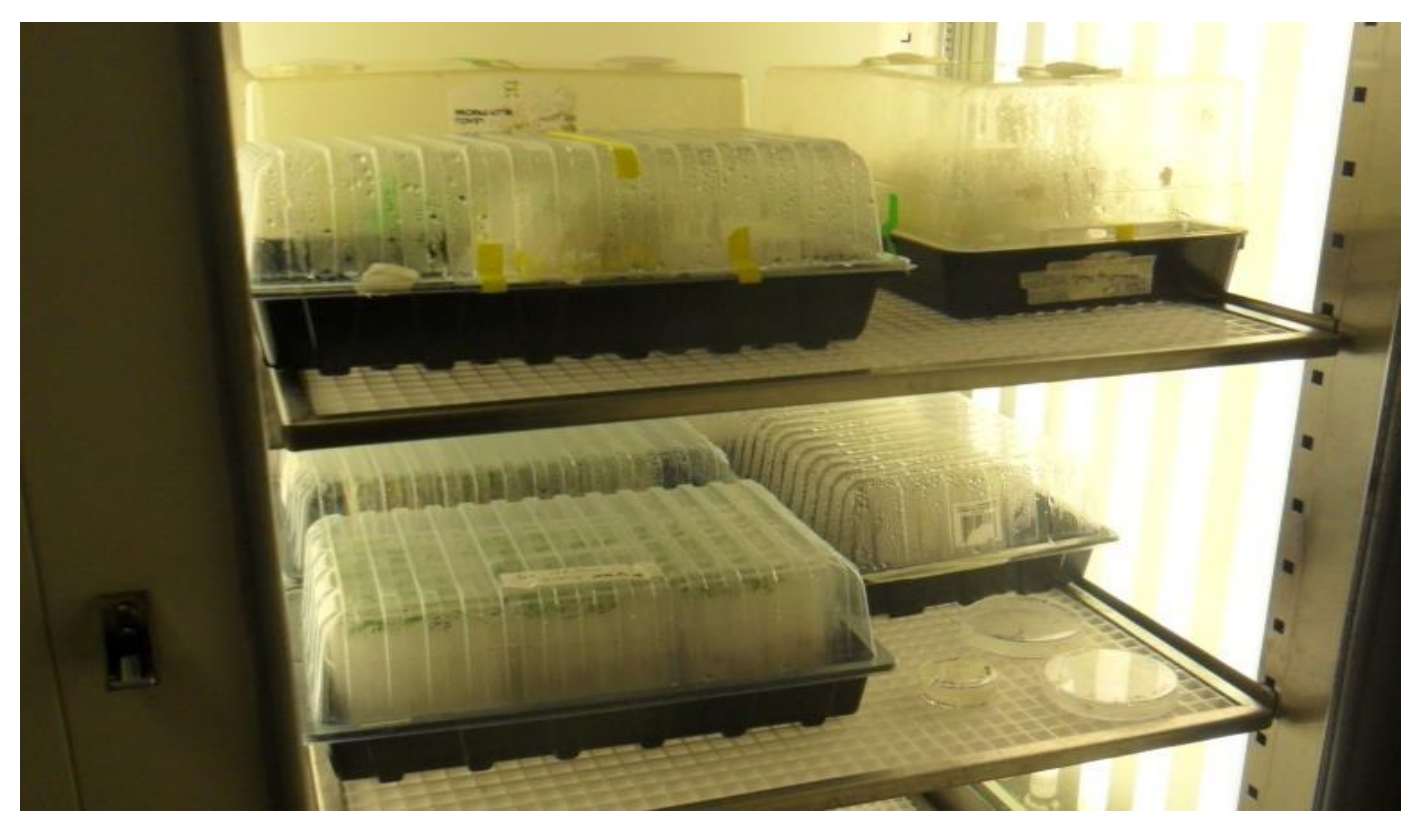

Figura 21. Incubación de las placas en cámara de crecimiento con luz y humedad controlada.

Una vez que las raíces estuvieron en condiciones de ser inoculadas, en cuanto a longitud y sanidad, se inocularon diez raíces por aislamiento y por 
ecotipo de $B d$, con tres réplicas, representando un total de 2100 raíces. Utilizando una jeringa estéril (0,1-5 ml), se aplicó el slurry suavemente sobre el ápice de cada una de las diez raíces por placa (Goddard et al., 2014) (Figura 22). Se incubaron 2 días en cámara de crecimiento (Figura 23) y se lavaron las raíces con abundante agua destilada estéril (Figura 24). A partir del lavado, se fotografiaron las raíces con una cámara digital Panasonic DMC-FZ18 cada 2 días, iniciando a los 2 días pos-inoculación (2dpi) hasta los 8 dpi. La longitud de la raíz con necrosis se midió con el software ImageJ (Abramoff et al., 2004). Para confirmar que los síntomas observados en las raíces se debían a las especies de Fusarium inoculadas y no a posibles contaminantes, se cortaron algunos fragmentos de raíz al final de los ensayos, se aislaron las especies presentes y se identificaron morfológicamente siguiendo la metodología descripta en el apartado anterior.

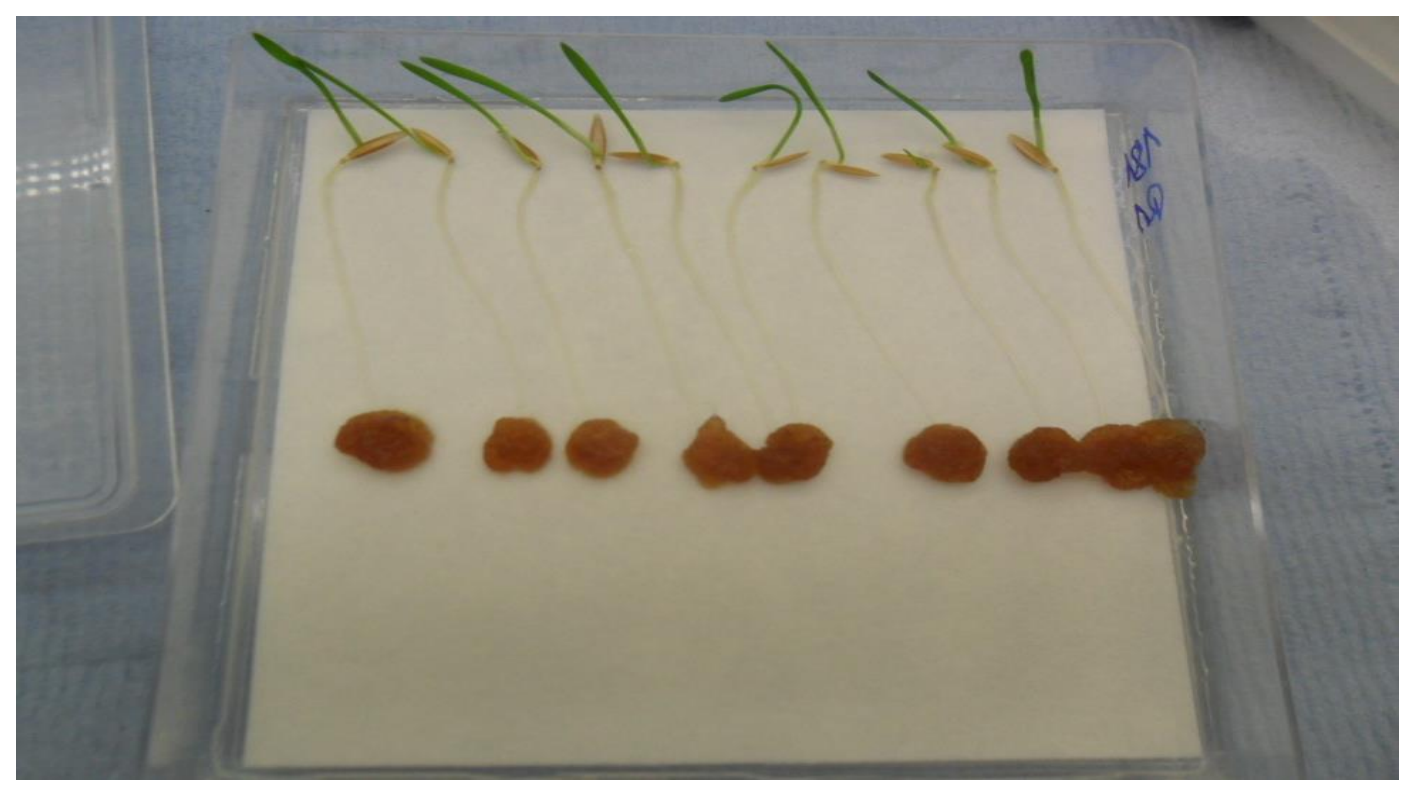

Figura 22. Inoculación de raíces. 


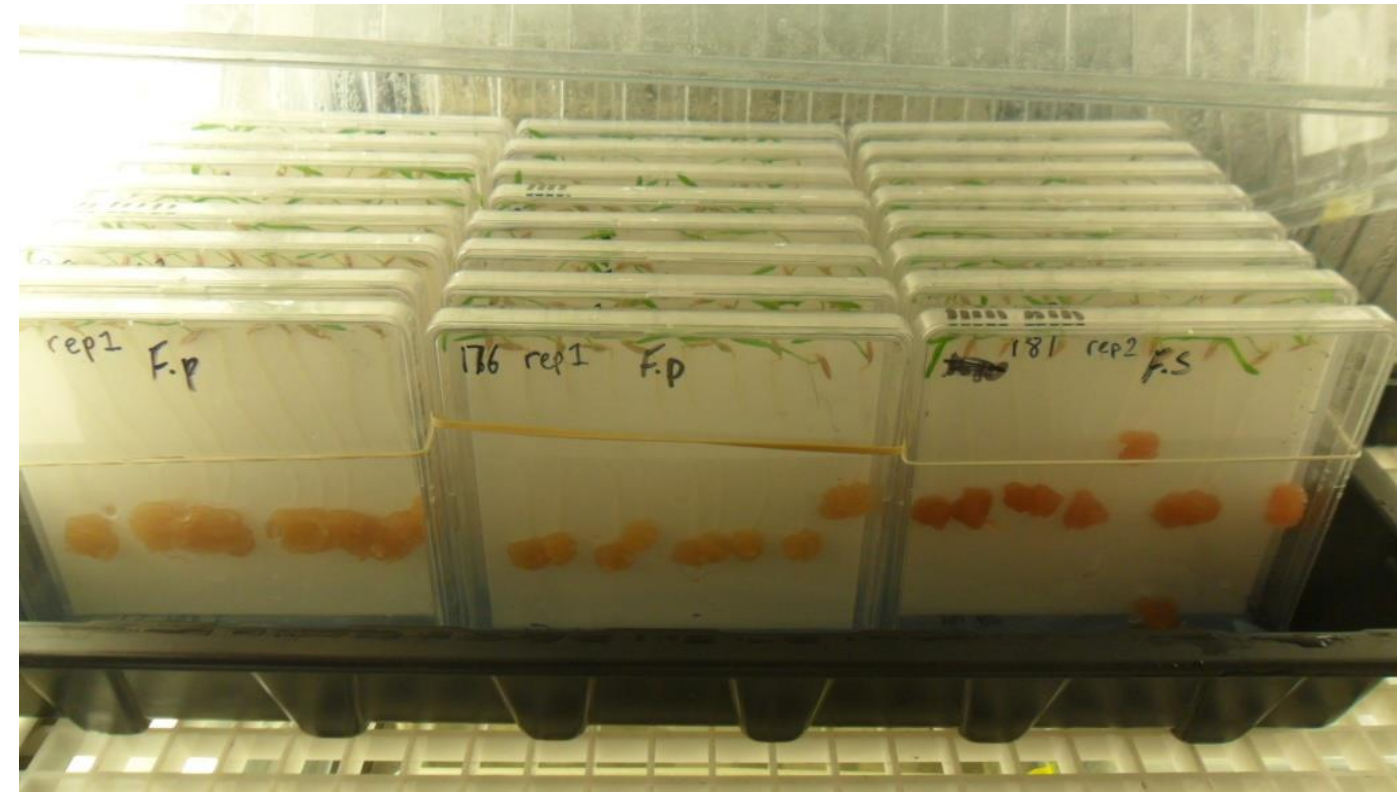

Figura 23. Incubación de raíces con slurry durante 2 días en cámara de crecimiento.

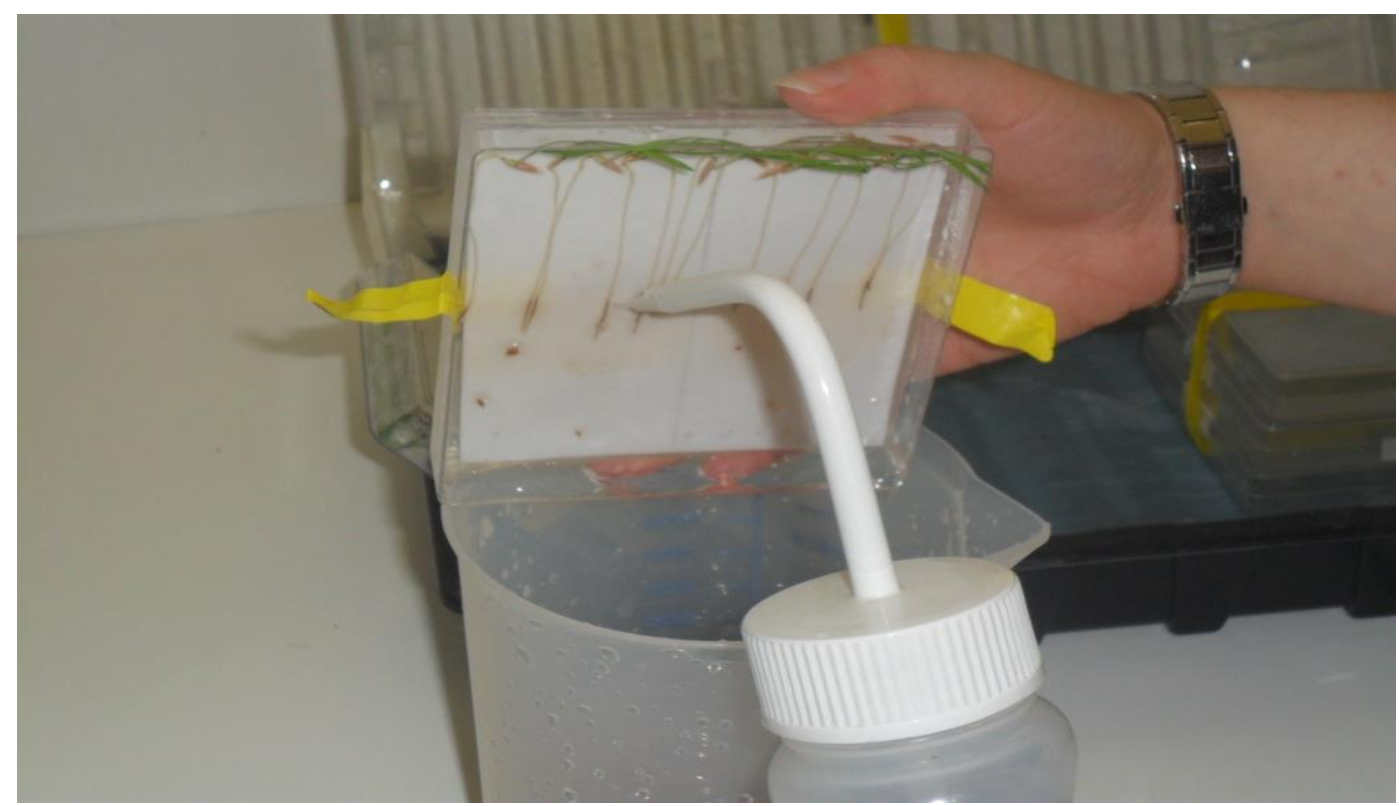

Figura 24. Lavado de raíces con agua estéril. 


\subsubsection{Análisis estadístico}

El área bajo las curvas de progreso de la enfermedad (AUDPC) se calculó mediante el método poligonal (Campbell y Madden, 1990). Los datos se sometieron a un análisis de la varianza (ANOVA) utilizando el software RStudio Versión 1.0.153 (R Core Team 2017). Los resultados se informaron como la media \pm error estándar de la media (SEM). Los niveles de significancia se establecieron mediante el uso de la prueba de Tukey en $\mathrm{P}<0,05$. 


\section{CAPÍTULO III:}

\section{Especies de Fusarium}

aisladas de granos de

\section{cebada y determinación de}

micotoxinas 


\subsection{Diversidad de Fusarium y micotoxinas}

3.1.1. Especies de Fusarium presentes en los granos de cebada y potencial producción de toxinas

De las 119 muestras analizadas, 96 presentaron crecimiento fúngico característico del género Fusarium. Las 23 muestras restantes mostraron crecimiento fúngico con aspecto no aparente a especies del género Fusarium. Se identificaron morfológicamente 1180 aislamientos de Fusarium de los cuales el $51,2 \%$ se correspondió con la especie F. graminearum (603 aislamientos) (Figura 25, Figura $26-$ a), el $26,2 \%$ con F. poae (309 aislamientos) (Figura 25, Figura 26 b) y el $22,6 \%$ con otras especies del género (268 aislamientos). Entre estas últimas, el 6,5\% se correspondieron a especies del complejo $F$. incarnatum - F. equiseti (77 aislamientos) (Figura 25, Figura 26 - c), el 5,6 \% a F. chlamydosporum (66 aislamientos) (Figura 25, Figura 26 - d), el 3,6 \% a F. oxysporum (43 aislamientos) (Figura 25, Figura 26 - e), el 2,5 \% a F. acuminatum (29 aislamientos) (Figura 25, Figura 26 - f), el 2,2 \% a F. proliferatum (26 aislamientos) (Figura 25, Figura $26-\mathrm{g}$ ), el 1,4 \% a F. tricinctum (17 aislamientos) (Figura 25, Figura 26 - h), el 0,6\% a F. cerealis (7 aislamientos) (Figura 25, Figura 26 - i) y el 0,2 \% a F. pseudograminearum (3 aislamientos) (Figura 25, Figura 26 j). 


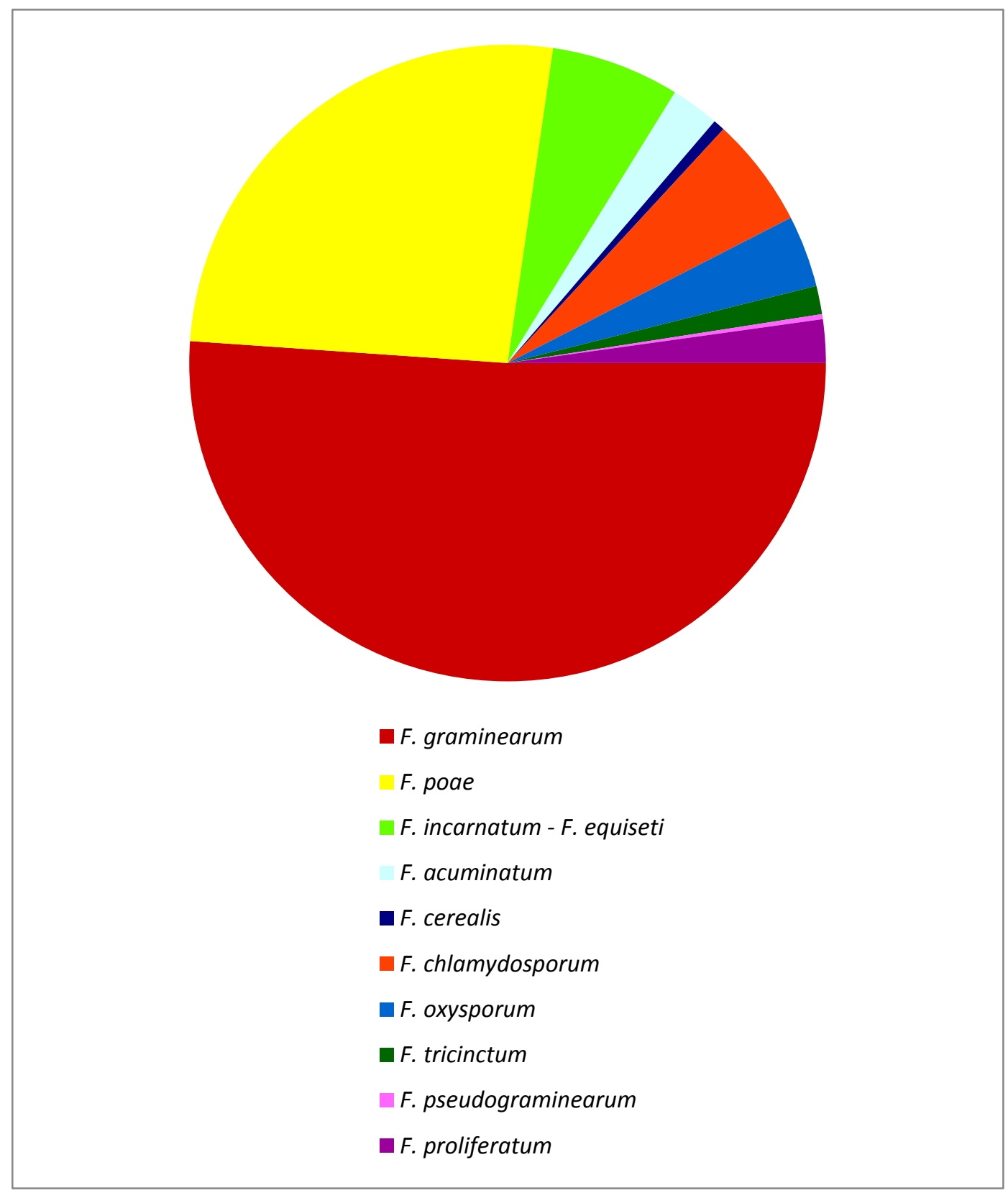

Figura 25. Diversidad y porcentaje de especies de Fusarium presentes en las muestras analizadas. 


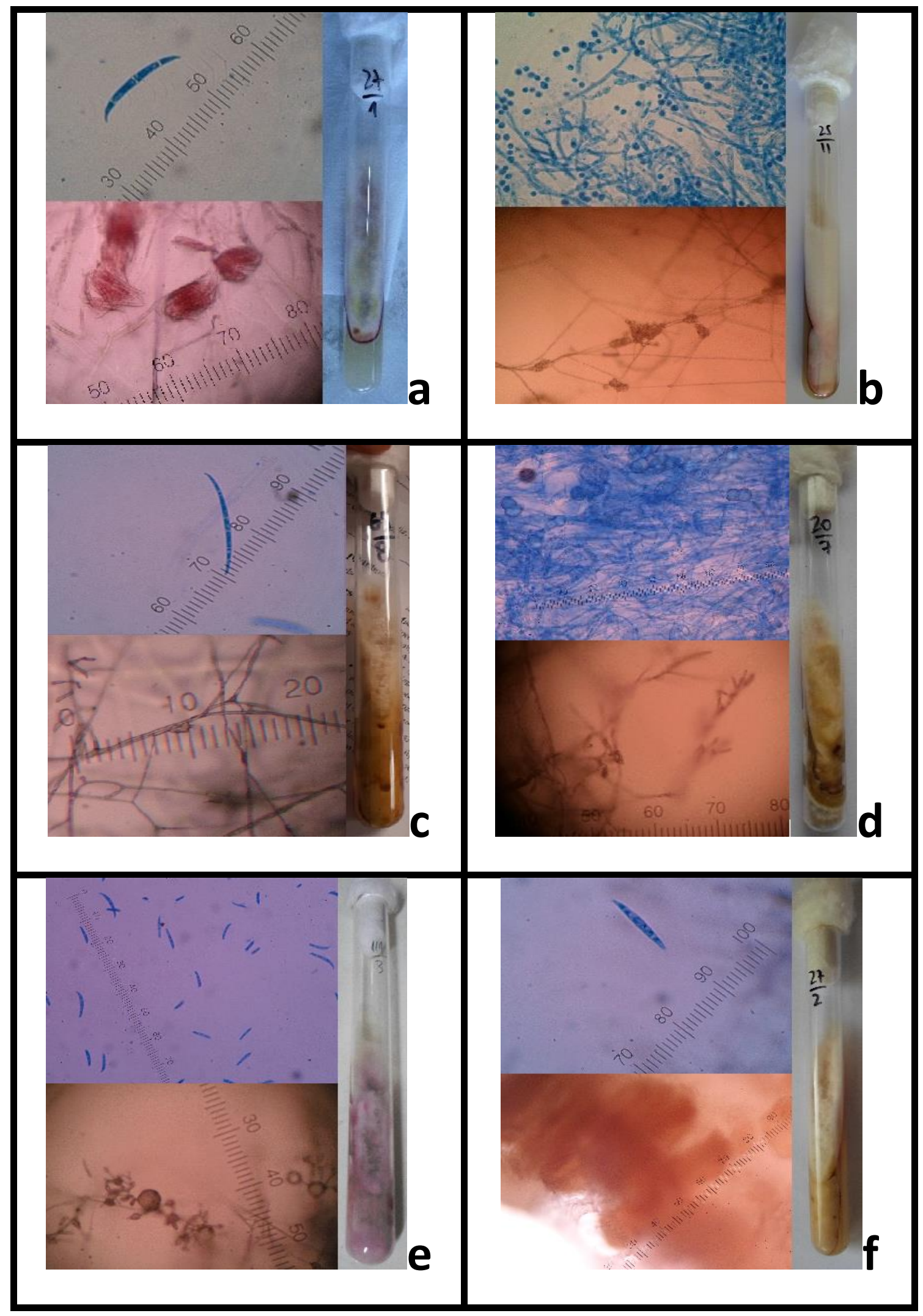




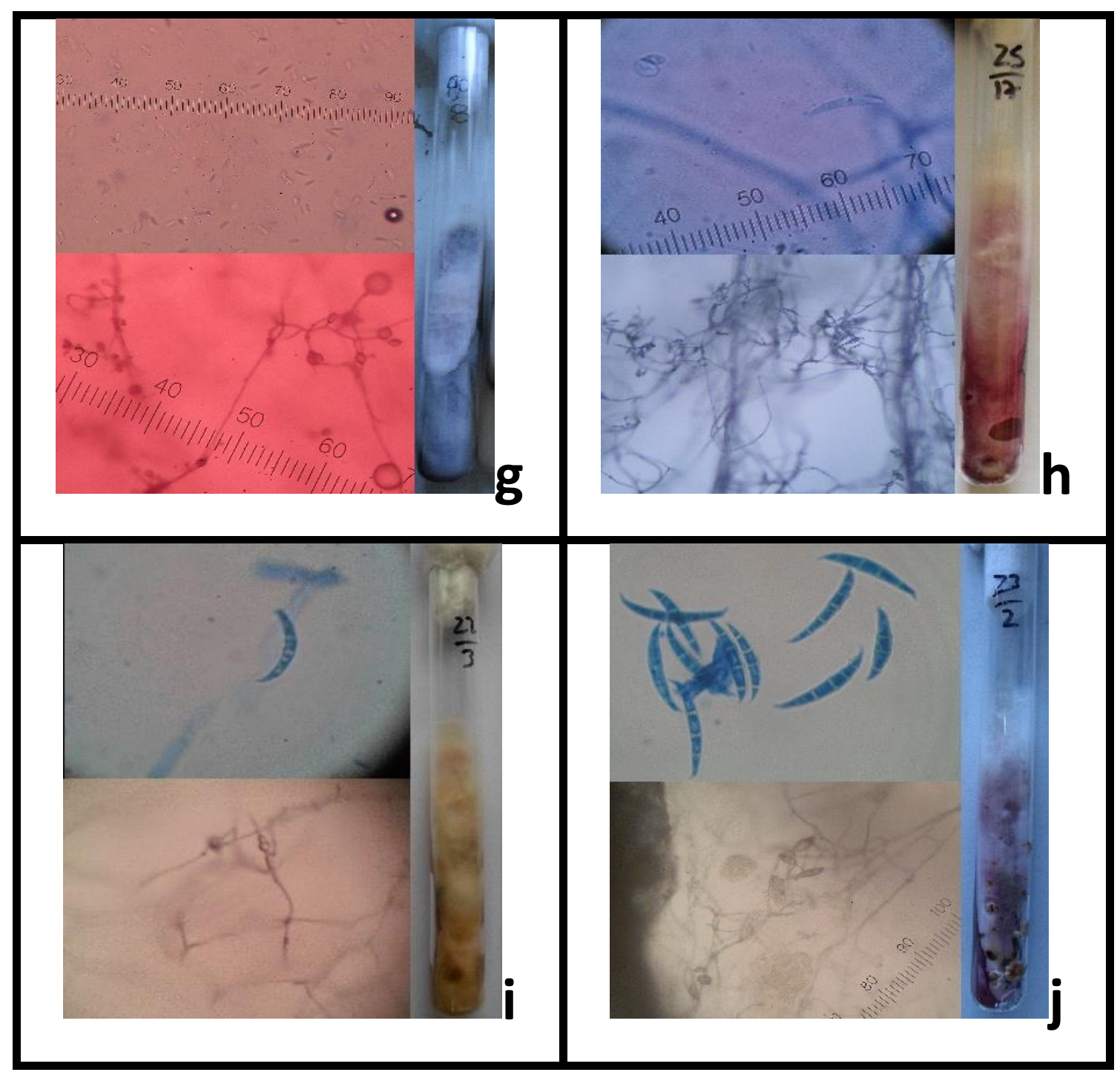

Figura 26. Observaciones microscópicas y tubo pico de flauta de las distintas especies de Fusarium aisladas de los granos de cebada. a- F. graminearum, b- F. poae, c- F. incarnatum - F. equiseti, d- F. clamydosporum, e- F. oxysporum, f- F. acuminatum, g- F. proliferatum, h- F. tricinctum, i- F. cerealis, j- F. pseudograminearum. 
Como se explicó en el capítulo "Materiales y Métodos", al ser Fusarium graminearum y F. poae las especies más aisladas entre las muestras analizadas, se realizó un análisis más exhaustivo de estas. Los aislamientos de $F$. graminearum se obtuvieron del $13,4 \%$ del total de muestras de cebada analizadas, los cuales variaron según el año analizado (Tabla 2; Figura 27): 22,7 \% (2012), 37,7 \% (2013) y 52,8 \% (2014). De esta misma forma, F. poae se aisló del $28,6 \%$ del total de muestras, con variaciones anuales de: $68,2 \%(2012), 37,7 \%$ (2013) y 75,0 \% (2014). Del $26,1 \%$ del total de muestras, se aisló tanto $F$. graminearum como F. poae, mientras que en 38 de las 119 muestras (31,9\%) no se aisló ni F. graminearum ni F. poae (Figura 27).

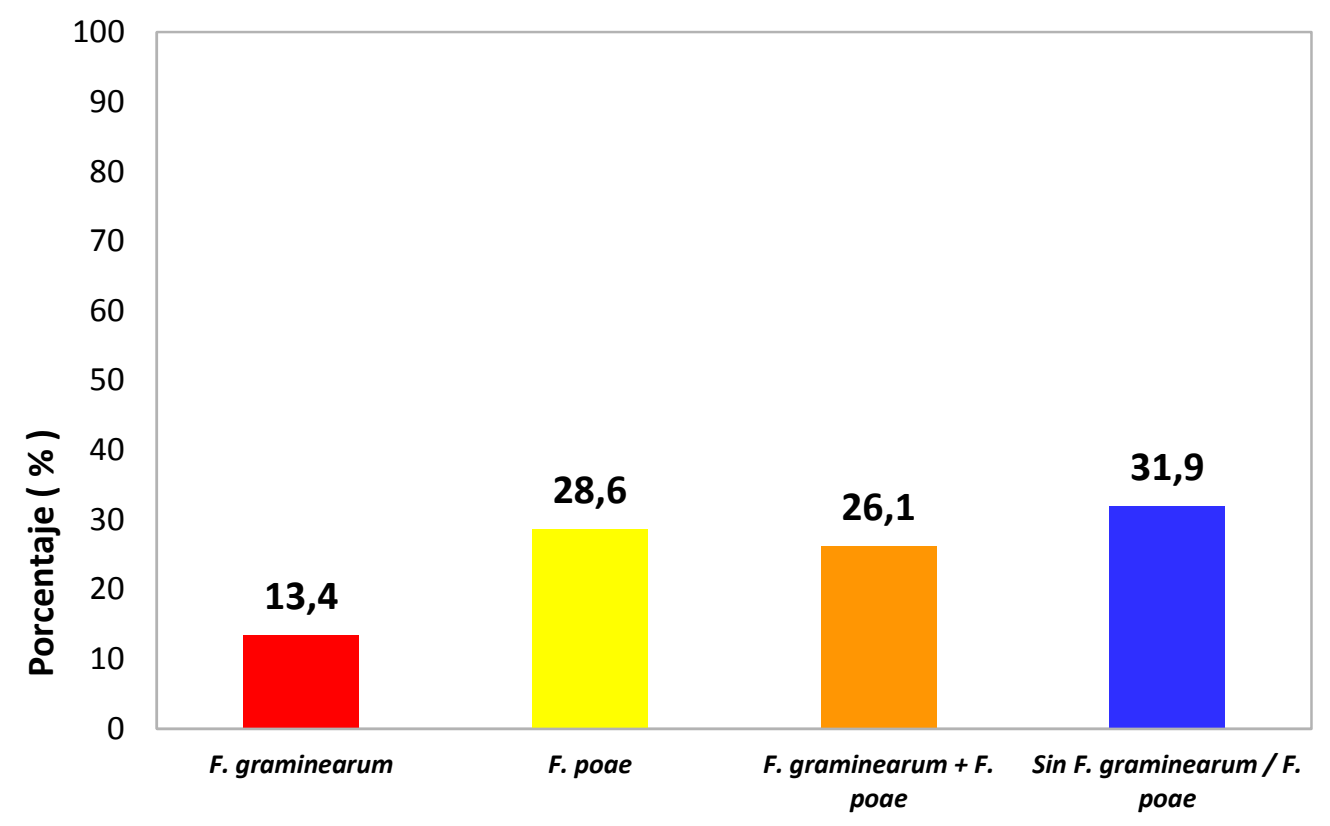

Figura 27. Porcentaje de muestras con o sin Fusarium graminearum y/o Fusarium poae. En la figura, el porcentaje detectado entre todos los aislamientos se grafica en la ordenada para cada una de las especies de Fusarium o su combinación indicada en la abscisa. 
Entre las 24 localidades muestreadas, en una sola no se aisló ni Fusarium graminearum ni F. poae (Saavedra, Buenos Aires). De manera opuesta, F. graminearum se aisló de 20 localidades diferentes y F. poae de 23 (Tabla 2; Figura 28). Con respecto a los genotipos de cebada muestreados, todos fueron hospedantes de Fusarium graminearum y/o F. poae (Tabla 2).

Todas las reacciones especie-específicas realizadas con los ADN de $F$. graminearum y F. poae amplificaron fragmentos de $\approx 400 \mathrm{pb}$ y $\approx 220 \mathrm{pb}$, respectivamente, lo cual confirma las identificaciones morfológicas. Además, a partir del ADN de los aislamientos de F. graminearum, se amplificó un fragmento de 282 pb que correspondía al genotipo DON y, a partir de los ADN de F. poae, un fragmento de 296 pb correspondiente al del genotipo NIV.

Se aislaron dos especies de Fusarium capaces de producir las toxinas antes mencionadas, F. pseudograminearum (potencial productora de DON) y F. cerealis (potencial productora de NIV). Sin embargo, estas especies se obtuvieron esporádicamente: F. cerealis solo de las muestras 14, 22, 35, 89, 90 y 96 (aislado de un solo grano por muestra analizada) y F. pseudograminearum solo de las muestras 16 y 23 (aislado de un solo grano por muestra analizada) (Tabla 2).

Tabla 2. Número de muestra, Genotipo de cebada, Localidad, Provincia y año de cosecha, concentración de micotoxinas presente y porcentaje de granos infectados con Fusarium graminearum $(F G)$ y Fusarium poae (FP) sobre el total de granos analizados. $\mathrm{NN}=$ dato no disponible. n.d. = no detectado. 


\begin{tabular}{|c|c|c|c|c|c|c|c|}
\hline \multirow[t]{2}{*}{ Muestra } & \multirow{2}{*}{$\begin{array}{l}\text { Genotipo } \\
\text { de cebada }\end{array}$} & \multirow[t]{2}{*}{ Localidad } & \multirow[t]{2}{*}{ Provincia/Año } & \multicolumn{2}{|c|}{$\begin{array}{c}\text { Concentración } \\
\text { de tricotecenos } \\
(\mu \mathrm{g} / \mathrm{g})\end{array}$} & \multicolumn{2}{|c|}{ \% Fusarium } \\
\hline & & & & DON & NIV & $F G$ & $F P$ \\
\hline 1 & NN & T. Lauquen & Buenos Aires/2012 & n.d. & 0,31 & 2 & 3 \\
\hline 2 & NN & Tres Arroyos & Buenos Aires/2012 & n.d. & 4,64 & n.d. & 0 \\
\hline 3 & Scarlett & Oliveros & Santa Fe/2012 & n.d. & n.d. & 1 & 1,5 \\
\hline 4 & NN & Azul & Buenos Aires/2012 & n.d. & 0,54 & n.d. & 0 \\
\hline 5 & NN & Azul & Buenos Aires/2012 & 0,14 & n.d. & n.d. & 0,5 \\
\hline 6 & Scarlett & T. Lauquen & Buenos Aires/2012 & n.d. & n.d. & 1,5 & 3 \\
\hline 7 & NN & Azul & Buenos Aires/2012 & n.d. & n.d. & n.d. & 0 \\
\hline 8 & NN & Azul & Buenos Aires/2012 & n.d. & n.d. & n.d. & 0,5 \\
\hline 9 & Scarlett & Azul & Buenos Aires/2012 & n.d. & n.d. & n.d. & 4 \\
\hline 10 & Scarlett & T. Lauquen & Buenos Aires/2012 & 0,38 & 0,74 & 12,5 & 1,5 \\
\hline 11 & Scarlett & Azul & Buenos Aires/2012 & n.d. & n.d. & n.d. & 0,5 \\
\hline 12 & Scarlett & Azul & Buenos Aires/2012 & n.d. & 0,22 & n.d. & 1,5 \\
\hline 13 & Scarlett & T. Lauquen & Buenos Aires/2012 & n.d. & n.d. & n.d. & 0 \\
\hline 14 & NN & Balcarce & Buenos Aires/2012 & n.d. & 0,33 & n.d. & 2 \\
\hline 15 & NN & Balcarce & Buenos Aires/2012 & n.d. & n.d. & n.d. & 0,5 \\
\hline 16 & NN & Lobería & Buenos Aires/2012 & n.d. & n.d. & 0,5 & 1 \\
\hline 17 & NN & Lobería & Buenos Aires/2012 & n.d. & n.d. & n.d. & 0 \\
\hline 18 & NN & Quequén & Buenos Aires/2012 & n.d. & n.d. & n.d. & 1 \\
\hline 19 & NN & Necochea & Buenos Aires/2012 & n.d. & n.d. & n.d. & 0 \\
\hline 20 & NN & San Cayetano & Buenos Aires/2012 & n.d. & n.d. & n.d. & 0 \\
\hline 21 & NN & Tres Arroyos & Buenos Aires/2012 & n.d. & n.d. & n.d. & 1 \\
\hline 22 & NN & C. Pringles & Buenos Aires/2013 & n.d. & n.d. & n.d. & 0,5 \\
\hline 23 & NN & C. Pringles & Buenos Aires/2013 & n.d. & n.d. & 0,5 & 0 \\
\hline 24 & NN & C. Suárez & Buenos Aires/2013 & n.d. & 0,7 & n.d. & 2 \\
\hline 25 & NN & La Madrid & Buenos Aires/2013 & n.d. & 3,42 & n.d. & 23 \\
\hline 26 & NN & Azul & Buenos Aires/2013 & n.d. & n.d. & n.d. & 0,5 \\
\hline 27 & NN & Azul & Buenos Aires/2013 & n.d. & n.d. & 1 & 0 \\
\hline 28 & Andreia & Tandil & Buenos Aires/2013 & n.d. & n.d. & n.d. & 0 \\
\hline
\end{tabular}




\begin{tabular}{|c|c|c|c|c|c|c|c|}
\hline \multirow[t]{2}{*}{ Muestra } & \multirow{2}{*}{$\begin{array}{l}\text { Genotipo } \\
\text { de cebada }\end{array}$} & \multirow[t]{2}{*}{ Localidad } & \multirow[t]{2}{*}{ Provincia/Año } & \multicolumn{2}{|c|}{$\begin{array}{c}\text { Concentración } \\
\text { de tricotecenos } \\
(\mu \mathrm{g} / \mathrm{g})\end{array}$} & \multicolumn{2}{|c|}{ \% Fusarium } \\
\hline & & & & DON & NIV & $F G$ & $F P$ \\
\hline 29 & NN & Azul & Buenos Aires/2013 & n.d. & n.d. & n.d. & 0 \\
\hline 30 & Scarlett & Necochea & Buenos Aires/2013 & n.d. & 0,1 & n.d. & 0,5 \\
\hline 31 & NN & Azul & Buenos Aires/2013 & n.d. & n.d. & 2,5 & 1 \\
\hline 32 & NN & Tandil & Buenos Aires/2013 & n.d. & n.d. & 0,5 & 1 \\
\hline 33 & NN & Balcarce & Buenos Aires/2013 & n.d. & n.d. & 1,5 & 0 \\
\hline 34 & NN & Balcarce & Buenos Aires/2013 & 0,89 & n.d. & 10 & 0 \\
\hline 35 & NN & Lobería & Buenos Aires/2013 & n.d. & n.d. & 3 & 0 \\
\hline 36 & NN & Lobería & Buenos Aires/2013 & n.d. & 0,94 & 2 & 0,5 \\
\hline 37 & NN & Necochea & Buenos Aires/2013 & n.d. & n.d. & 2 & 0,5 \\
\hline 38 & NN & Necochea & Buenos Aires/2013 & n.d. & 0,1 & 0,5 & 0 \\
\hline 39 & NN & San Cayetano & Buenos Aires/2013 & n.d. & n.d. & n.d. & 0,5 \\
\hline 40 & NN & Tres Arroyos & Buenos Aires/2013 & n.d. & n.d. & n.d. & 11,5 \\
\hline 41 & NN & C. Pringles & Buenos Aires/2013 & n.d. & n.d. & n.d. & 0 \\
\hline 42 & NN & C. Pringles & Buenos Aires/2013 & n.d. & n.d. & n.d. & 0 \\
\hline 43 & NN & C. Suárez & Buenos Aires/2013 & n.d. & n.d. & n.d. & 0 \\
\hline 44 & NN & Saavedra & Buenos Aires/2013 & n.d. & 5,78 & n.d. & 0 \\
\hline 45 & NN & Guaminí & Buenos Aires/2013 & n.d. & n.d. & n.d. & 0,5 \\
\hline 46 & NN & Daireaux & Buenos Aires/2013 & n.d. & n.d. & n.d. & 1 \\
\hline 47 & NN & Olavarría & Buenos Aires/2013 & n.d. & 0,26 & 1,5 & 1 \\
\hline 48 & Scarlett & T. Lauquen & Buenos Aires/2013 & n.d. & n.d. & 1 & 0 \\
\hline 49 & Andreia & NN & NN/2013 & n.d. & 0,49 & n.d. & 0 \\
\hline 50 & Andreia & NN & NN/2013 & n.d. & 0,62 & n.d. & 0 \\
\hline 51 & Scarlett & NN & NN/2013 & n.d. & n.d. & n.d. & 1,5 \\
\hline 52 & Scarlett & NN & NN/2013 & n.d. & n.d. & n.d. & 0 \\
\hline 53 & Explorer & Bordenave & Buenos Aires/2013 & n.d. & n.d. & n.d. & 0 \\
\hline 54 & Scrabble & Bordenave & Buenos Aires/2013 & n.d. & n.d. & n.d. & 0 \\
\hline 55 & Shakira & Bordenave & Buenos Aires/2013 & n.d. & n.d. & n.d. & 0 \\
\hline 56 & Andreia & Bordenave & Buenos Aires/2013 & n.d. & n.d. & n.d. & 0 \\
\hline
\end{tabular}




\begin{tabular}{|c|c|c|c|c|c|c|c|}
\hline \multirow[t]{2}{*}{ Muestra } & \multirow{2}{*}{$\begin{array}{l}\text { Genotipo } \\
\text { de cebada }\end{array}$} & \multirow[t]{2}{*}{ Localidad } & \multirow[t]{2}{*}{ Provincia/Año } & \multicolumn{2}{|c|}{$\begin{array}{c}\text { Concentración } \\
\text { de tricotecenos } \\
(\mu \mathrm{g} / \mathrm{g})\end{array}$} & \multicolumn{2}{|c|}{ \% Fusarium } \\
\hline & & & & DON & NIV & $F G$ & $F P$ \\
\hline 57 & Carisma & Bordenave & Buenos Aires/2013 & n.d. & n.d. & n.d. & 0 \\
\hline 58 & Scarlett & Bordenave & Buenos Aires/2013 & 0,91 & n.d. & 0,5 & 1,5 \\
\hline 59 & Explorer & Miramar & Buenos Aires/2013 & 0,27 & n.d. & 6,5 & 0 \\
\hline 60 & Scrabble & Miramar & Buenos Aires/2013 & 0,99 & n.d. & 1,5 & 0 \\
\hline 61 & Shakira & Miramar & Buenos Aires/2013 & n.d. & n.d. & n.d. & 0 \\
\hline 62 & Andreia & Miramar & Buenos Aires/2013 & 12,01 & n.d. & 3,5 & 0 \\
\hline 63 & Carisma & Miramar & Buenos Aires/2013 & 1,35 & n.d. & 6,5 & 0 \\
\hline 64 & Scarlett & Miramar & Buenos Aires/2013 & n.d. & n.d. & 2 & 0 \\
\hline 65 & Explorer & Paraná & Entre Ríos/2013 & n.d. & n.d. & n.d. & 0 \\
\hline 66 & Scrabble & Paraná & Entre Ríos/2013 & 0,16 & n.d. & n.d. & 0 \\
\hline 67 & Shakira & Paraná & Entre Ríos/2013 & 0,2 & 0,85 & n.d. & 0 \\
\hline 68 & Andreia & Paraná & Entre Ríos/2013 & n.d. & n.d. & n.d. & 0 \\
\hline 69 & Carisma & Paraná & Entre Ríos/2013 & n.d. & n.d. & 0,5 & 0,5 \\
\hline 70 & Scarlett & Paraná & Entre Ríos/2013 & n.d. & n.d. & n.d. & 0 \\
\hline 71 & Explorer & Dorrego & Buenos Aires/2013 & n.d. & n.d. & n.d. & 0 \\
\hline 72 & Scrabble & Dorrego & Buenos Aires/2013 & n.d. & n.d. & 0,5 & 0,5 \\
\hline 73 & Shakira & Dorrego & Buenos Aires/2013 & n.d. & n.d. & n.d. & 0,5 \\
\hline 74 & Andreia & Dorrego & Buenos Aires/2013 & n.d. & n.d. & n.d. & 1 \\
\hline 75 & Carisma & Dorrego & Buenos Aires/2013 & n.d. & 6,25 & n.d. & 1 \\
\hline 76 & Scarlett & Dorrego & Buenos Aires/2013 & n.d. & n.d. & n.d. & 1 \\
\hline 77 & Explorer & 9 de Julio & Buenos Aires/2013 & n.d. & n.d. & 1 & 0,5 \\
\hline 78 & Scrabble & 9 de Julio & Buenos Aires/2013 & n.d. & n.d. & n.d. & 0 \\
\hline 79 & Shakira & 9 de Julio & Buenos Aires/2013 & n.d. & n.d. & n.d. & 0 \\
\hline 80 & Carisma & 9 de Julio & Buenos Aires/2013 & n.d. & n.d. & 1 & 0,5 \\
\hline 81 & Scarlett & 9 de Julio & Buenos Aires/2013 & n.d. & n.d. & n.d. & 0 \\
\hline 82 & Scarlett & Azul & Buenos Aires/2013 & n.d. & n.d. & n.d. & 0 \\
\hline 83 & Andreia & Azul & Buenos Aires/2014 & n.d. & n.d. & 0,5 & 0 \\
\hline 84 & Scarlett & NN & NN/2014 & n.d. & n.d. & n.d. & 2 \\
\hline
\end{tabular}




\begin{tabular}{|c|c|c|c|c|c|c|c|}
\hline \multirow[t]{2}{*}{ Muestra } & \multirow{2}{*}{$\begin{array}{l}\text { Genotipo } \\
\text { de cebada }\end{array}$} & \multirow[t]{2}{*}{ Localidad } & \multirow[t]{2}{*}{ Provincia/Año } & \multicolumn{2}{|c|}{$\begin{array}{c}\text { Concentración } \\
\text { de tricotecenos } \\
(\mu \mathrm{g} / \mathrm{g})\end{array}$} & \multicolumn{2}{|c|}{ \% Fusarium } \\
\hline & & & & DON & NIV & FG & $F P$ \\
\hline 85 & NN & Tandil & Buenos Aires/2014 & n.d. & 5,13 & 10 & 7 \\
\hline 86 & NN & Tandil & Buenos Aires/2014 & 1,34 & 4,1 & 28,5 & 2,5 \\
\hline 87 & NN & Ayacucho & Buenos Aires/2014 & 2,2 & n.d. & 19 & 3 \\
\hline 88 & NN & Ayacucho & Buenos Aires/2014 & 1,26 & n.d. & 6,5 & 4,5 \\
\hline 89 & NN & Ayacucho & Buenos Aires/2014 & 1,22 & n.d. & 31 & 0,5 \\
\hline 90 & NN & Ayacucho & Buenos Aires/2014 & 3,74 & 0,36 & 17,5 & 0,5 \\
\hline 91 & NN & Ayacucho & Buenos Aires/2014 & 5,04 & n.d. & 29,5 & 0,5 \\
\hline 92 & NN & Balcarce & Buenos Aires/2014 & n.d. & n.d. & 8 & 0,5 \\
\hline 93 & NN & Balcarce & Buenos Aires/2014 & 5,32 & 4 & 23 & 0,5 \\
\hline 94 & NN & Lobería & Buenos Aires/2014 & 7,48 & 1,3 & 22 & 0 \\
\hline 95 & NN & Lobería & Buenos Aires/2014 & 0,24 & 0,2 & 9,5 & 0 \\
\hline 96 & NN & Loberia & Buenos Aires/2014 & 0,4 & n.d. & 9 & 1 \\
\hline 97 & NN & Quequén & Buenos Aires/2014 & 0,24 & n.d. & 6 & 0,5 \\
\hline 98 & NN & Lobería & Buenos Aires/2014 & 0,74 & n.d. & 7,5 & 0 \\
\hline 99 & NN & Necochea & Buenos Aires/2014 & 0,51 & 0,75 & 3,5 & 2 \\
\hline 100 & NN & San Cayetano & Buenos Aires/2014 & n.d. & 4,58 & 1,5 & 6 \\
\hline 101 & NN & Tres Arroyos & Buenos Aires/2014 & n.d. & n.d. & 0,5 & 1,5 \\
\hline 102 & NN & C. Pringles & Buenos Aires/2014 & n.d. & 0,42 & n.d. & 0 \\
\hline 103 & NN & C. Suarez & Buenos Aires/2014 & n.d. & n.d. & n.d. & 1 \\
\hline 104 & NN & C. Suárez & Buenos Aires/2014 & n.d. & n.d. & n.d. & 1 \\
\hline 105 & NN & Guaminí & Buenos Aires/2014 & n.d. & 4,61 & n.d. & 3 \\
\hline 106 & NN & C. Suárez & Buenos Aires/2014 & n.d. & n.d. & 0,5 & 3,5 \\
\hline 107 & NN & Guaminí & Buenos Aires/2014 & n.d. & n.d. & 1 & 1 \\
\hline 108 & NN & Bolívar & Buenos Aires/2014 & n.d. & 4,64 & n.d. & 3,5 \\
\hline 109 & NN & Bolívar & Buenos Aires/2014 & 9,53 & n.d. & n.d. & 2,5 \\
\hline 110 & Scarlett & NN & Buenos Aires/2014 & n.d. & 2,17 & n.d. & 0 \\
\hline 111 & Andreia & NN & Buenos Aires/2014 & 7,35 & n.d. & n.d. & 0 \\
\hline 112 & Andreia & NN & NN/2014 & 0,71 & n.d. & n.d. & 0 \\
\hline
\end{tabular}




\begin{tabular}{|c|c|c|c|c|c|c|c|}
\hline \multirow[t]{2}{*}{ Muestra } & \multirow{2}{*}{$\begin{array}{l}\text { Genotipo } \\
\text { de cebada }\end{array}$} & \multirow[t]{2}{*}{ Localidad } & \multirow[t]{2}{*}{ Provincia/Año } & \multicolumn{2}{|c|}{$\begin{array}{c}\text { Concentración } \\
\text { de tricotecenos } \\
(\mu \mathrm{g} / \mathrm{g})\end{array}$} & \multicolumn{2}{|c|}{$\%$ Fusarium } \\
\hline & & & & DON & NIV & $F G$ & $F P$ \\
\hline 113 & Explorer & Bordenave & Buenos Aires/2014 & 6,29 & n.d. & n.d. & 0 \\
\hline 114 & Scarlett & Bordenave & Buenos Aires/2014 & n.d. & n.d. & n.d. & 0 \\
\hline 115 & Scarlett & Miramar & Buenos Aires/2014 & n.d. & 2,63 & n.d. & 0,5 \\
\hline 116 & Andreia & Paraná & Entre Ríos/2014 & n.d. & 4,8 & n.d. & 11,5 \\
\hline 117 & Explorer & Paraná & Entre Ríos/2014 & n.d. & 7,71 & n.d. & 10 \\
\hline 118 & Scarlett & Paraná & Entre Ríos/2014 & n.d. & 0,59 & n.d. & 2 \\
\hline 119 & Scrabble & Paraná & Entre Ríos/2014 & n.d. & 5,81 & n.d. & 8,5 \\
\hline
\end{tabular}
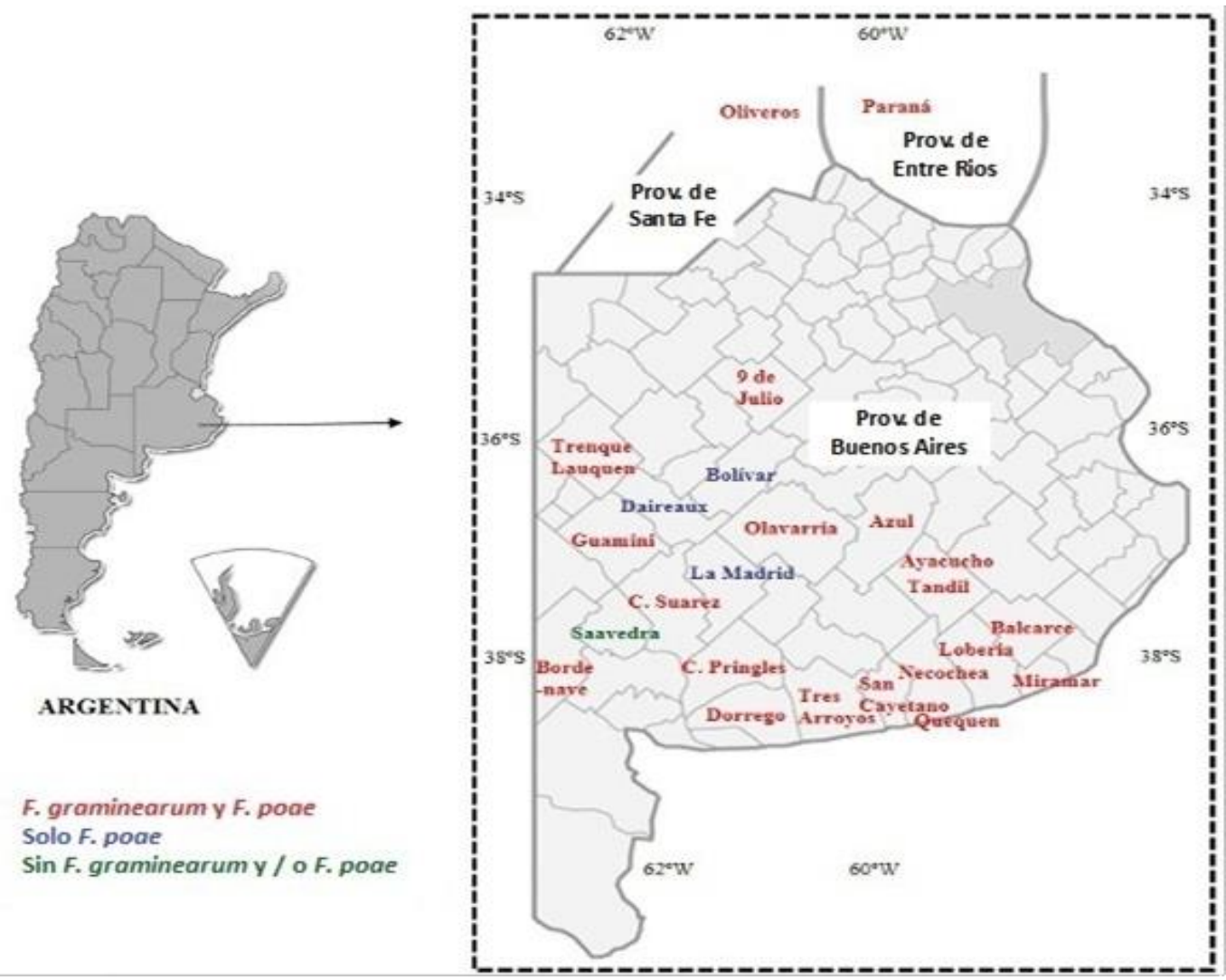

Figura 28. Localidades muestreadas y presencia de Fusarium graminearum y/o Fusarium poae. Clave de color para la identificación de las especies de Fusarium más aisladas de las muestras en el mapa del panel derecho: rojo, Fusarium graminearum y Fusarium poae; azul, Fusarium poae solo; verde, sin Fusarium graminearum/Fusarium poae. 


\subsubsection{Contaminación de los granos con micotoxinas}

De las muestras analizadas, el $16 \%$ (19/119) contenían DON en distintas concentraciones (promedio de 2,6 $\mu \mathrm{g} / \mathrm{g}$ ), de los cuales el 44 \% superó los límites máximos establecidos por la Comisión Europea (promedio de 5,24 $\mu \mathrm{g} / \mathrm{g}$ ) (Tabla 2). Una muestra de cebada (Muestra 62, Tabla 2) de Miramar (Localidad de la costa de la Provincia de Buenos Aires) exhibió el nivel más alto de DON (12 g/g; Tabla 2; Figura 28). Por otro lado, el $22 \%$ de las muestras presentaban distintos valores de concentración de NIV (promedio de 2,36 $\mu \mathrm{g} / \mathrm{g}$ ), y una muestra (Muestra 117, Tabla 2) de Paraná (Localidad de la Provincia de Entre Ríos; Figura 28) contenía la concentración más alta $(7,71 \mu \mathrm{g} / \mathrm{g})$. El $7 \%$ de las muestras presentaba concentraciones de DON y NIV en forma conjunta, mientras que el 56 $\%$ de las muestras presentaban valores por debajo del valor de detección (Tabla 2; Figura 29). 


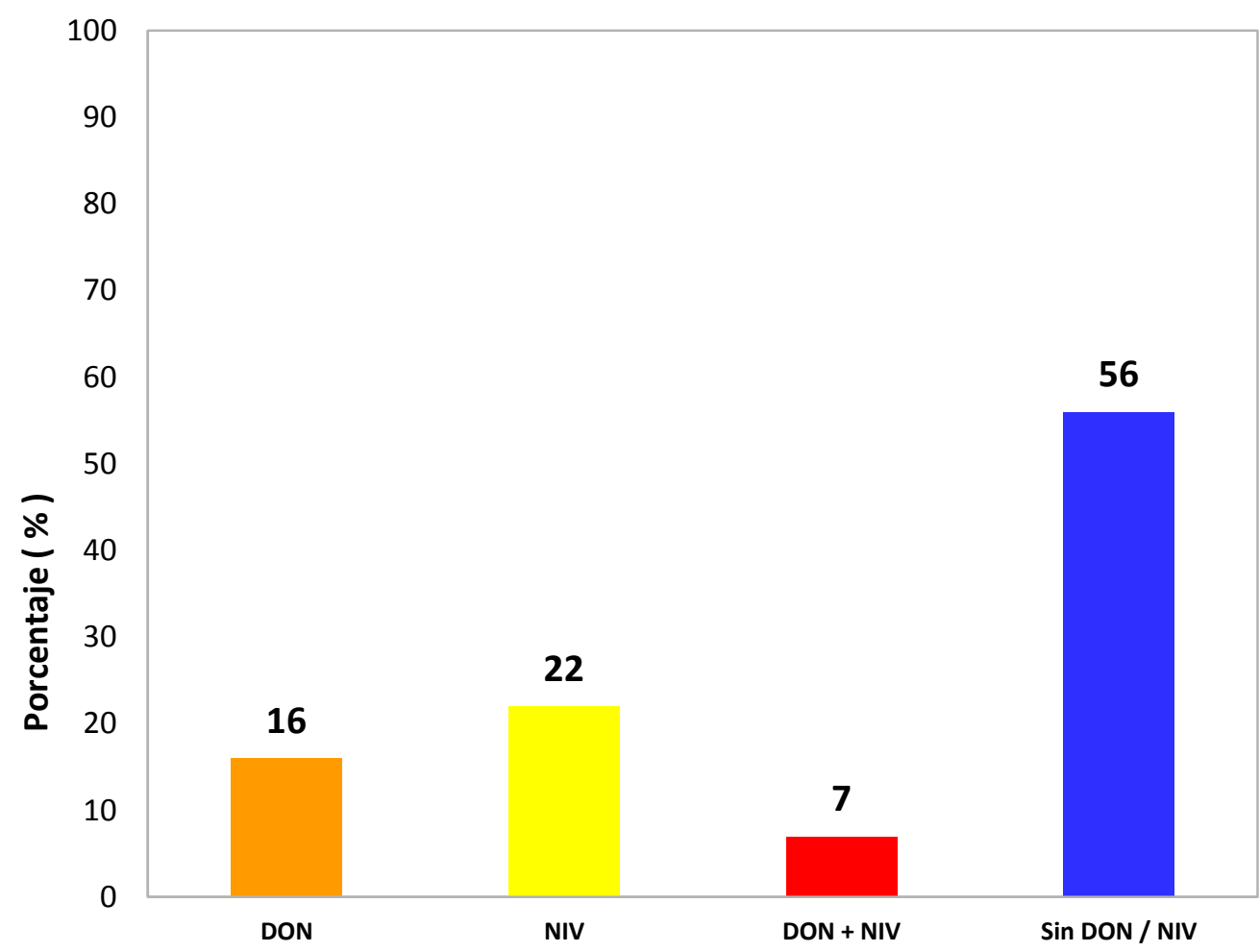

Figura 29. Porcentaje de muestras con o sin deoxynivalenol (DON) y/o nivalenol (NIV). En la figura, el porcentaje de tricotecenos detectados entre todas las muestras analizadas se representa en la ordenada de solo DON (16\%), solo NIV (22\%), DON y NIV (7\%), y sin DON ni NIV (56\%) como se indica en la abscisa.

El $45 \%$ de las muestras contenía al menos uno de los dos tricotecenos evaluados, donde las muestras del 2014 contenían un porcentaje de toxinas significativamente mayor que las de 2012 y/o 2013 (tabla 3).

De las localidades muestreadas, en solo tres no se detectaron ni DON ni NIV (Oliveros, 9 de Julio y Daireaux; Tabla 2; Figura 28), mientras que DON fue detectado en 12 localidades diferentes y NIV en 19 (Tabla 2). Se cuantificaron distintas concentraciones de DON y/o NIV en todos los genotipos de cebada analizados. 
Tabla 3. Porcentajes de muestras con micotoxinas por año de muestreo. Desoxynivalenol (DON), Nivalenol (NIV).

\begin{tabular}{|c|c|c|c|}
\cline { 2 - 4 } \multicolumn{1}{c|}{} & 2012 & 2013 & 2014 \\
\hline \% con DON & 9 & 13 & 47 \\
\hline \% con NIV & 27 & 18 & 47 \\
\hline \% sin micotoxina & 64 & 69 & 6 \\
\hline
\end{tabular}

\subsubsection{Relación entre presencia de Fusarium y micotoxinas}

Las frecuencias de ocurrencia de Fusarium graminearum y F. poae fueron de 0,85 y 0,92, respectivamente. Los coeficientes de correlación entre el porcentaje de presencia de F. graminearum y la contaminación por DON y el porcentaje de presencia de $F$. poae y la contaminación por NIV también fueron estadísticamente significativos con valores de $p<0,0001, r=0,39$ y $p<0,0001, r=$ 0,50, respectivamente. Además, el coeficiente de correlación calculado como:

número total de F. graminearum + F. poae / presencia de DON + NIV

fue estadísticamente significativo $(p<0,0001, r=0,40)$. 


\subsubsection{Datos climáticos}

Los datos climáticos recolectados de las localidades consideradas como representativas del muestreo se presentan en la Tabla 4 y en la Figura 30. Se analizaron las precipitaciones acumuladas (Figura 30a), temperaturas medias (Figura 30b) y humedades relativas (Figura 30c), durante el período de floración del cultivo, registradas en las localidades seleccionadas durante el 2012, 2013 y 2014. La mayoría de los datos fueron obtenidos del Servicio Meteorológico Nacional. Los datos pertenecientes a la localidad de Bordenave fueron facilitados por el INTA de la región.

Tabla 4. Temperaturas medias, precipitaciones acumuladas y humedades relativas de las localidades representativas al muestreo durante los años muestreados.

\begin{tabular}{|l|c|c|c|c|c|c|c|c|c|}
\cline { 2 - 11 } \multicolumn{1}{c|}{} & \multicolumn{3}{c|}{ Precipitaciones $(\mathrm{mm})$} & \multicolumn{3}{c|}{ Temperatura $\left({ }^{\circ} \mathrm{C}\right)$} & \multicolumn{3}{c|}{ Humedad Relativa (\%) } \\
\cline { 2 - 11 } & 2012 & 2013 & 2014 & 2012 & 2013 & 2014 & 2012 & 2013 & 2014 \\
\hline Azul & 85,0 & 107,0 & 108,0 & 17,4 & 16,0 & 16,5 & 73,0 & 71,0 & 71,0 \\
\hline Balcarce & 60,0 & 113,0 & 95,5 & 16,8 & 15,5 & 16,5 & 66,0 & 76,0 & 76,0 \\
\hline Bordenave & 100,0 & 45,3 & 107,3 & 20,6 & 17,5 & 17,2 & 64,0 & 64,0 & 65,5 \\
\hline Miramar & 44,0 & 82,0 & 144,0 & 16,0 & 15,7 & 16,0 & 73,0 & 79,0 & 81,0 \\
\hline Necochea & 33,0 & 88,0 & 23,0 & 17,8 & 16,1 & 17,7 & 66,0 & 78,0 & 73,4 \\
\hline Paraná & 183,0 & 173,0 & 55,4 & 20,9 & 20,9 & 22,1 & 68,0 & 65,0 & 63,0 \\
\hline
\end{tabular}



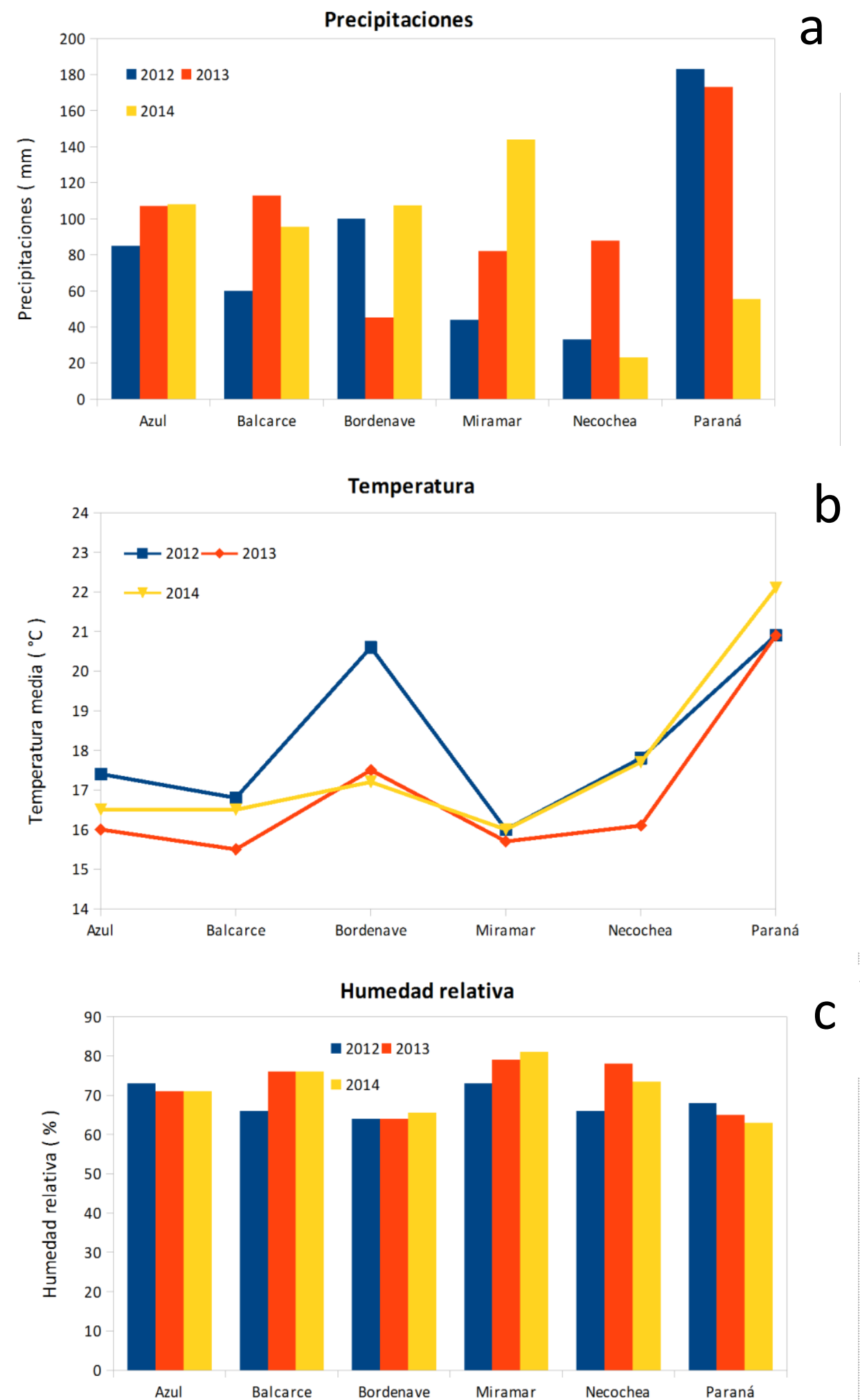

Figura 30. a- Precipitación acumulada, temperatura media y humedad relativa en el período de floración de la cebada (15 de octubre al 15 de noviembre). La clave de color indica cada año muestreado: azul, 2012; naranja, 2013; y amarillo, 2014. 


\subsection{Discusión}

Varios autores de distintas partes del mundo, por ejemplo en Italia y Reino Unido, han analizado la diversidad de especies de Fusarium causantes de la fusariosis de la espiga en cebada y han demostrado que la ocurrencia cambió a lo largo de diferentes años (Beccari et al., 2017; Nielsen et al., 2014). Sin embargo, en general, las principales especies de Fusarium identificadas en los granos de cebada fueron F. avenaceum, F. graminearum, F. poae y F. tricinctum (Beccari et al., 2017; Nielsen et al., 2014). En este trabajo, las principales especies de Fusarium halladas en los granos de cebada fueron F. graminearum, F. poae, F. incarnatum - F. equiseti, F. chlamydosporum y F. oxysporum. Entre las especies aisladas con menor frecuencia, se identificó a F. tricinctum por primera vez en granos de cebada y, aunque no fue un objetivo del presente trabajo de tesis, se realizaron los correspondientes "postulados de Koch", comprobándose su patogenicidad en este cultivo.

Actualmente, F. graminearum es considerada la especie prevaleciente en granos de cereales pequeños, como lo es el trigo y la cebada (Osborne et al., 2007; Bourdages et al., 2006), aunque muchos estudios han demostrado una alta frecuencia de aparición de otras especies como F. poae (Dinolfo et al., 2014). En este trabajo, se observó que los granos de cebada cosechados durante 20122014 estaban colonizados principalmente con Fusarium graminearum y F. poae, y aunque el número de aislamientos de $F$. graminearum fue mayor que el de $F$. 
poae (604 y 309, respectivamente), el porcentaje de muestras con $F$. poae fue mayor que con F. graminearum (54,7\% y 39,5\%, respectivamente). También se observó que todos los genotipos de cebada muestreados fueron hospedantes de F. graminearum y/o F. poae.

En general, las temperaturas cálidas (alrededor de $28^{\circ} \mathrm{C}$ ) y las condiciones de mayor humedad favorecen la infección por Fusarium graminearum, aunque las temperaturas alrededor de $25^{\circ} \mathrm{C}$ y condiciones de humedad no muy elevadas lo hacen para F. poae (Xu et al., 2008). En este estudio, algunas áreas muestreadas se encontraban muy cercanas entre sí (Figura 28), las fechas de siembra de los cultivos fueron distintas y las condiciones climáticas generales fueron variables (Figura 30), lo que provocó que la temperatura y la humedad promedio durante el período de floración de la cebada fueran diferentes entre las distintas localidades. Aparentemente, las diferencias en las condiciones climáticas dentro de las áreas muestreadas no fueron suficientes para cambiar de manera drástica la composición de las especies de Fusarium, y F. graminearum (potencial productor de DON) y F. poae (potencial productor de NIV) resultaron ser las especies más adaptadas para la infección de las principales áreas de cultivo de cebada en Argentina. Sin embargo, se aislaron otras especies de Fusarium capaces de producir tricotecenos aunque en menor cantidad, como lo son F. pseudograminearum y F. cerealis. La presencia de estas especies estaría indicando la necesidad de realizar continuos monitoreos en la región de producción de cebada. 
Cabe aclarar, dado que no se contó con el mismo número de muestras de cebada y/o localidades analizadas por año, no se realizó un análisis comparativo entre los años muestreados.

Todos los aislamientos de Fusarium graminearum y F. poae seleccionados para verificar la potencial producción de toxinas amplificaron fragmentos característicos para DON y NIV, respectivamente, como se observó previamente para otros aislamientos obtenidos de granos de cebada en Argentina (Castañares et al., 2014; Castañares et al., 2016; Dinolfo et al., 2014). Los aislamientos de $F$. graminearum no amplificaron el fragmento característico de potencial producción de NIV, como fue observado en estudios anteriores (Castañares et al., 2014).

Dado que se observó una alta frecuencia de F. graminearum y F. poae en muchas muestras, se podrían anticipar contaminaciones con los tricotecenos que son capaces de producir estas especies. De hecho, los análisis de correlación confirmaron estas expectativas ya que las muestras que presentaron altas concentraciones de toxinas coincidieron con una alta carga fúngica. Anteriormente, se observaron correlaciones similares con respecto a $F$. graminearum para DON y F. poae para NIV en trigo (Yli-Mattila et al., 2008; Martínez et al., 2014; Nielsen et al., 2011), cebada (Schöneberg et al., 2016; Nielsen et al., 2011) y avena (Fredlund et al., 2013).

Los estudios antes mencionados y los del presente trabajo, presentan resultados similares en lo referido a la correlación observada entre las especies 
de Fusarium y la cuantificación de micotoxinas en cereales de granos pequeños. Sin embargo, estas observaciones podrían variar dependiendo de la especificidad de las técnicas utilizadas. Por ejemplo, los resultados obtenidos de técnicas tradicionales de aislamiento fúngico, donde algunas especies poseen capacidad de desarrollo menor que otras y, de esta forma no sería posible identificarlas, resultarían diferentes a los obtenidos mediante la cuantificación de ADN por PCR en tiempo real. Lo mismo se supone con respecto a los métodos de detección y/o cuantificación de toxinas.

A través del análisis químico para determinar la presencia de DON y NIV, se observó que el $45 \%$ de las muestras contenían micotoxinas en concentraciones variables y que el NIV era la toxina predominante en las muestras de cebada. En Suiza, un estudio similar reveló que la especie predominante era Fusarium graminearum y que el DON fue la micotoxina más común, seguida del NIV (Schöneberg et al., 2016). Sin embargo, aunque la ocurrencia de F. poae fue mayor que la de F. graminearum en granos de cebada del Reino Unido, prevaleció la contaminación con DON (Nielsen et al., 2014). Es interesante pensar que los granos de cebada europeos podrían estar contaminados con otras especies productoras de DON, pero que en Argentina estas especies no se encuentren por distintas razones (por ejemplo, condiciones climáticas diferentes entre continentes) o que hasta el momento no se hayan podido aislar, como es el caso de F. culmorum. Además, las diferentes condiciones ambientales, como la temperatura y la humedad, podrían favorecer 
la producción de NIV sobre la de DON en algunas zonas de cultivo de cebada de Argentina.

Como se mencionó anteriormente, en este trabajo no se analizaron la misma cantidad de muestras por año y/o localidad. Sin embargo, los datos en la Figura 30 indicarían la influencia de las condiciones climáticas en la presencia de especies de Fusarium y la consecuente contaminación por toxinas, como fue observado en otros trabajos (Beccari et al., 2017; Nielsen et al., 2014). Por ejemplo, en Paraná (Localidad de la Provincia de Entre Ríos), donde las prácticas agronómicas fueron las mismas a lo largo de los años de estudio, las muestras del 2013 (Muestras 65-70, Tabla 2) contenían menor cantidad de Fusarium y/o micotoxinas que las de 2014 (Muestras 116-119, Tabla 2). Además, en las muestras del año 2014 de la misma localidad se registró una mayor cantidad de NIV y F. poae, en concordancia con las condiciones ambientales (menores porcentaje de humedad relativa y precipitaciones acumuladas) que prevalecían en ese momento (Figura 30). De modo contrario, ciertas muestras de distintas zonas geográficas, y por ende distintas condiciones climáticas, presentaron tanto F. graminearum como F. poae y altas cantidades de DON y NIV (Muestras 86 y 93, Tabla 2), lo que permite deducir que las condiciones generales para la producción de DON y/o NIV fueron adecuadas y diferentes. Por otro lado, las especies de Fusarium podrían competir por el mismo nicho ecológico y así, producir más toxinas que si las especies estuvieran aisladas. Además, ciertos genotipos de cebada, por ejemplo, las muestras de Miramar del 2013 (Muestras 59-64, Tabla 2), contenían diferentes porcentajes de F. graminearum y distintas 
concentraciones de DON, lo que hace suponer que existen diferentes respuestas entre el genotipo de cebada y la presencia de Fusarium, como fue observado por Beccari et al. (2016).

En América del Sur, y específicamente en Brasil y Uruguay, se detectaron altas concentraciones de DON en los granos de cebada malteada (Pan et al., 2007; Piacentini et al., 2015). En este estudio, del total de las muestras contaminadas con DON, 12 (10\% de las muestras totales, pero el $44 \%$ de las muestras con DON) contenían niveles más altos que los límites permitidos en países de Europa. Argentina exporta granos de cebada a diferentes países con y sin límites establecidos de DON, mientras que parte de la producción se utiliza a nivel nacional, donde aún no se han establecido los niveles máximos de DON y/o NIV.

Si bien se habla de profundizar en los estudios acerca de la ocurrencia de NIV y sus efectos en la salud humana y animal (Comisión Europea, 2006), aun no existe a nivel mundial ninguna regulación relacionada a esta micotoxina. En este estudio, se ha detectado NIV en el $29 \%$ de las muestras totales, con valores promedios de 2,36 $\mu \mathrm{g} / \mathrm{g}$. Estos valores incentivan a poner mayor atención sobre esta micotoxina, actualmente subestimada, que se manifiesta en mayores proporciones y concentraciones, presentando aún mayor toxicidad que el DON. 


\section{CAPÍTULO IV:}

\section{Evaluación de las}

interacciones entre

\section{ecotipos de Brachypodium}

distachyon y especies de

\section{Fusarium en raíces}




\subsection{Fusarium / Brachypodium distachyon}

La técnica de inoculación de raíces de Brachypodium distachyon utilizando el método por slurry de Fusarium resultó ser eficiente y sencilla. Todos los aislamientos de las distintas especies de Fusarium con los que se trabajó fueron capaces de colonizar y generar síntomas en las raíces inoculadas. Por otro lado, todos los ejemplares de los distintos ecotipos de B. distachyon mostraron susceptibilidad a la inoculación con los distintos aislamientos de Fusarium utilizados (Figura 31). 

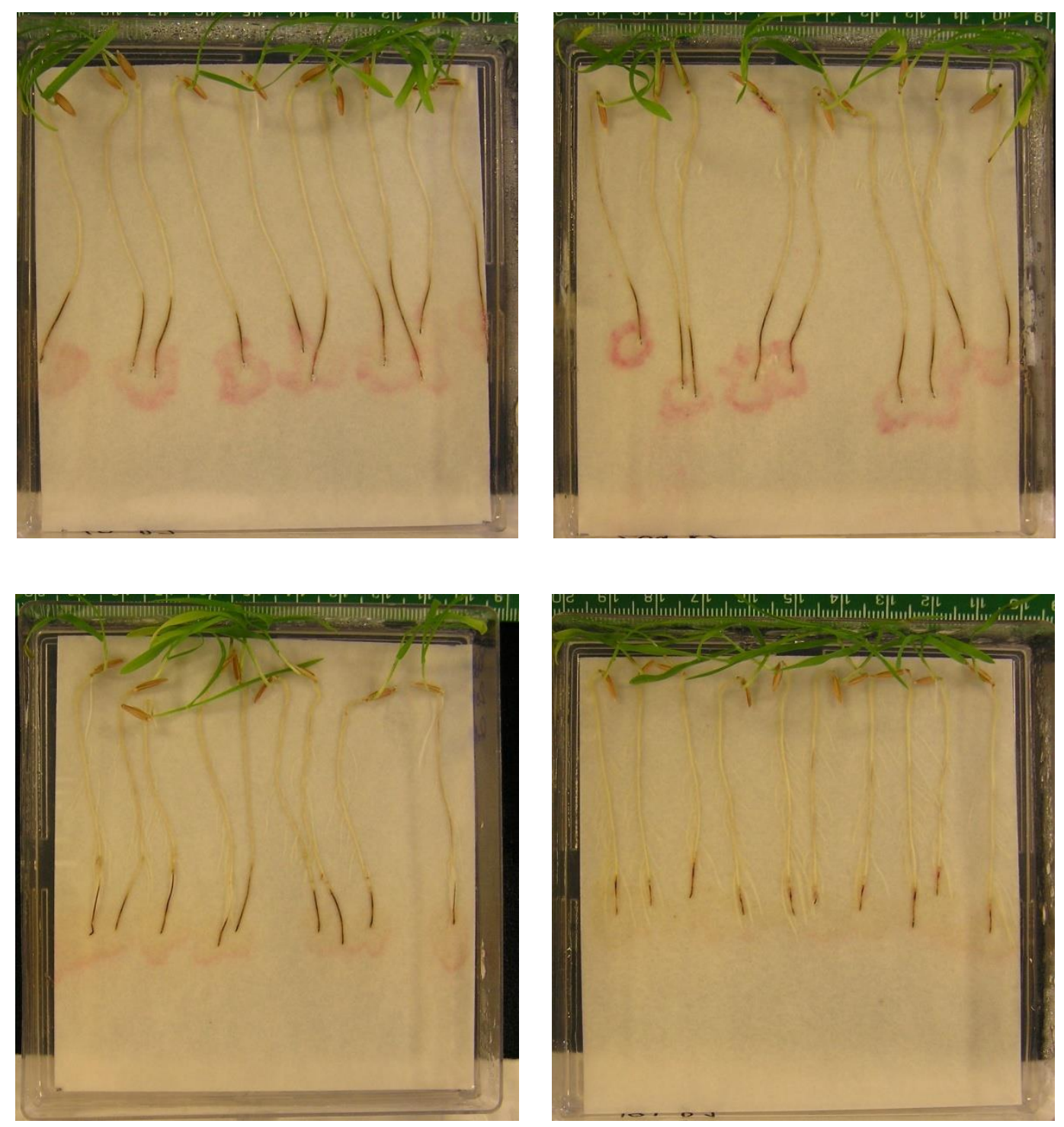

Figura 31. Necrosis en raíces de Brachypodium distachyon inoculadas con aislamientos de Fusarium graminearum (arriba a la izquierda), Fusarium pseudograminearum (arriba a la derecha), Fusarium cerealis (abajo a la izquierda) y Fusarium poae (abajo a la derecha) fotografiadas a los 8 días después de la inoculación. 
El análisis estadístico evidenció interacción significativa entre los aislamientos de Fusarium y los ecotipos de Brachypodium utilizados. Teniendo presente esta información, se realizaron observaciones generales de los resultados obtenidos, en referencia a las especies de Fusarium y a los ecotipos de Brachypodium (Tabla 5 y Anexo).

Tabla 5. Análisis de la varianza del AUDPC de la necrosis causada por Fusarium en raíces de Brachypodium distachyon. Sum Sq: suma de los cuadrados, Df: Grados de libertad, $* * *$ : significativo a un valor de $p=0,05$

$\begin{array}{lrrrrr} & \text { Sum Sq } & \text { Df } & \mathrm{F} \text { value } & & \operatorname{Pr}(>\mathrm{F}) \\ \text { Ecotipo } & 180.11 & 6 & 21.8602 & <2.2 \mathrm{e}-16 * * * \\ \text { Aislamiento } & 1046.51 & 9 & 84.6793<2.2 \mathrm{e}-16 * * * \\ \text { Ecotipo:Aislamiento } & 548.74 & 54 & 7.4004<2.2 \mathrm{e}-16 * * * \\ \text { Residuals } & 2729.85 & 1988 & & \end{array}$

4.1.1. Comportamiento de aislamientos de Fusarium en raíces de Brachypodium

Con respecto a la interacción aislamiento-ecotipo, se observaron diferencias estadísticamente significativas $(p<0,0001, n=2057)$ (Tabla 5, 6 y Anexo). Los ecotipos como Irán, Israel y Sudáfrica fueron más susceptibles al aislamiento 107-18 FG, mientras que 8-1 FP fue el aislamiento menos agresivo 
con estos ecotipos. Además, los ecotipos de Pakistán y Uruguay se vieron más afectados por 16-2 FPS, mientras que 8-1 FP fue el aislamiento menos agresivo en estos ecotipos de Brachypodium. Por otro lado, Afganistán mostró más necrosis radicular con 106-35 FPS, mientras que los valores más bajos de AUDPC se observaron con el aislamiento 8-1 FP. Además, 107-18 FG fue el aislamiento más agresivo para el ecotipo Bd 21, mientras que 9-5 FP fue el aislamiento menos agresivo en este ecotipo.

Entre los diferentes aislamientos de Fusarium analizados, se observaron diferencias en la agresividad. Para este análisis, se tuvieron en cuenta las medias de los valores de AUDPC de los aislamientos en los distintos ecotipos de Brachypodium (Tabla 6 y Anexo). El aislamiento más agresivo fue 107-18 FG (4,92 $\pm 0,07$ ) con los valores más altos de AUPDC, seguido de 16-2 FPS $(4,46 \pm 0,08)$,

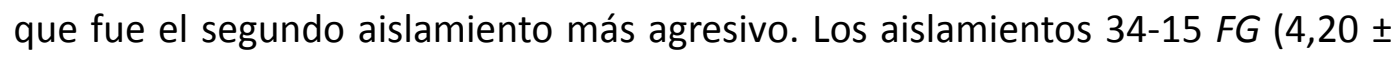
0,07), 102-43 FG (4,01 $\pm 0,08), 112-10$ FC $(4,01 \pm 0,08), 106-35$ FPS $(3,90 \pm 0,10)$ y 105-41 FC $(3,74 \pm 0,10)$, mostraron valores intermedios de AUDPC. Por otro lado, 25-5 FP $(3,31 \pm 0,10), 9-5 F P(3,12 \pm 0,11)$ y $8-1 F P(2,22 \pm 0,11)$ fueron los menos agresivos con porcentajes más bajos de necrosis radicular observados.

\subsubsection{Análisis de especies de Fusarium}

El comportamiento de las especies con los distintos ecotipos de Brachypodium se analizó observando las medias de los AUDPC según la especie 
de Fusarium analizada. Fusarium graminearum mostró valores de AUDPC de 4,37 $\pm 0,05$, F. pseudograminearum de $4,18 \pm 0,07$, F. cerealis de $3,87 \pm 0,06$ y F. poae de 2,88 $\pm 0,06$ (Tabla 6)

\subsubsection{Susceptibilidad de los distintos ecotipos de Brachypodium}

Las medias de los resultados obtenidos mostraron los siguientes valores en cuanto a la susceptibilidad entre los diferentes ecotipos de Brachypodium. El ecotipo de Afganistán mostró valores de AUDPC de 4,10 \pm 0,08, el de Israel 4,08 \pm

0,08 y el de Pakistán $4,18 \pm 0,08$, el de $B d 213,41 \pm 0,09$, el de Irán 3,44 $\pm 0,10$, el de Sudáfrica 3,70 $\pm 0,08$ y el de Uruguay 3,61 $\pm 0,08$ (Tabla 6). 
Tabla 6. Interacción entre ecotipos de Brachypodium distachyon y aislamientos de Fusarium. Medias de los valores de AUDPC al 8 dpi.

\begin{tabular}{|c|c|c|c|c|c|c|c|c|c|c|c|}
\hline \multirow{3}{*}{$\begin{array}{r}\text { Ecotipos B. } \\
\text { distachyon }\end{array}$} & \multicolumn{2}{|c|}{ Fusarium cerealis $(F C)$} & \multicolumn{3}{|c|}{ Fusarium graminearum (FG) } & \multicolumn{3}{|c|}{ Fusarium poae (FP) } & \multicolumn{2}{|c|}{ Fusarium pseudograminearum (FPS) } & \multirow{3}{*}{$\begin{array}{c}\text { Medias } \\
4,01 \pm 0,08\end{array}$} \\
\hline & $105-41 F C$ & $112-10 F C$ & 34-15 FG & $102-43 F G$ & $107-18 \mathrm{FG}$ & 8-1FP & 9-5FP & 25-5FP & 16-2 FPS & 106-35 FPS & \\
\hline & $3,86 \pm 0,23^{\text {cd }}$ & $4,25 \pm 0,23^{\mathrm{bcd}}$ & $4,64 \pm 0,23^{\mathrm{abc}}$ & $4,44 \pm 0,23^{a b c}$ & $5,07 \pm 0,22^{\mathrm{ab}}$ & $2,65 \pm 0,23^{e}$ & $2,82 \pm 0,23^{e}$ & $3,38 \pm 0,22^{\mathrm{de}}$ & $4,58 \pm 0,23^{\mathrm{abc}}$ & $5,30 \pm 0,23^{a}$ & \\
\hline $\mathrm{Bd} 21$ & $2,75 \pm 0,22^{\text {cd }}$ & $4,46 \pm 0,23$ a & $4,21 \pm 0,21^{\mathrm{ab}}$ & $3,35 \pm 0,21^{\mathrm{bc}}$ & $4,91 \pm 0,24^{a}$ & $2,79 \pm 0,22^{c}$ & $1,76 \pm 0,22^{\mathrm{d}}$ & $3,33 \pm 0,21^{b c}$ & $4,23 \pm 0,23^{\mathrm{ab}}$ & $2,69 \pm 0,21^{\text {cd }}$ & $3,41 \pm 0,09$ \\
\hline Irán & $4,30 \pm 0,21^{\mathrm{bc}}$ & $3,78 \pm 0,21^{\mathrm{bcd}}$ & $4,43 \pm 0,21^{\mathrm{ab}}$ & $2,70 \pm 0,22^{\mathrm{de}}$ & $5,48 \pm 0,21^{a}$ & $1,50 \pm 0,22^{f}$ & $2,40 \pm 0,21^{\text {ef }}$ & $3,14 \pm 0,21^{\mathrm{de}}$ & $3,33 \pm 0,21^{\text {bcde }}$ & $3,25 \pm 0,21^{\text {cde }}$ & $3,44 \pm 0,10$ \\
\hline Israel & $4,03 \pm 0,21^{b c}$ & $4,44 \pm 0,21^{\mathrm{abc}}$ & $4,83 \pm 0,21^{\mathrm{ab}}$ & $4,22 \pm 0,21 \mathrm{bc}$ & $5,23 \pm 0,21^{a}$ & $2,04 \pm 0,21^{d}$ & $3,55 \pm 0,21^{c}$ & $3,97 \pm 0,21^{\mathrm{bc}}$ & $4,58 \pm 0,21^{\mathrm{ab}}$ & $3,97 \pm 0,21^{\text {bc }}$ & $4,08 \pm 0,08$ \\
\hline Pakistán & $3,25 \pm 0,22^{\mathrm{de}}$ & $4,23 \pm 0,21^{\text {abcd }}$ & $3,55 \pm 0,21^{\text {cde }}$ & $4,73 \pm 0,21^{\mathrm{ab}}$ & $4,62 \pm 0,21$ ab & $3,02 \pm 0,21^{\mathrm{e}}$ & $4,82 \pm 0,22^{\mathrm{ab}}$ & $3,90 \pm 0,22^{\text {bcde }}$ & $5,12 \pm 0,21^{a}$ & $4,47 \pm 0,21^{\mathrm{abc}}$ & $4,18 \pm 0,08$ \\
\hline Sudáfrica & $3,60 \pm 0,21^{\mathrm{bc}}$ & $3,13 \pm 0,21^{c}$ & $4,33 \pm 0,21^{\mathrm{ab}}$ & $4,35 \pm 0,21^{\mathrm{ab}}$ & $4,79 \pm 0,21^{a}$ & $1,43 \pm 0,21^{\mathrm{d}}$ & $3,20 \pm 0,21^{c}$ & $3,24 \pm 0,21^{c}$ & $4,69 \pm 0,19^{a}$ & $4,09 \pm 0,21^{\mathrm{ab}}$ & $3,70 \pm 0,08$ \\
\hline Uruguay & $4,30 \pm 0,21^{\mathrm{ab}}$ & $3,85 \pm 0,21^{\mathrm{abc}}$ & $3,46 \pm 0,21^{b c}$ & $4,27 \pm 0,21^{\mathrm{ab}}$ & $4,29 \pm 0,22^{\mathrm{ab}}$ & $2,19 \pm 0,21^{d}$ & $3,28 \pm 0,21^{c}$ & $2,19 \pm 0,21^{d}$ & $4,59 \pm 0,21^{\mathrm{a}}$ & $3,73 \pm 0,21^{\text {abc }}$ & $3,61 \pm 0,08$ \\
\hline \multirow{2}{*}{ Medias } & $3,74 \pm 0,10$ & $4,01 \pm 0,08$ & $4,20 \pm 0,07$ & $4,01 \pm 0,08$ & $4,92 \pm 0,07$ & $2,22 \pm 0,11$ & $3,12 \pm 0,11$ & $3,31 \pm 0,10$ & $4,46 \pm 0,08$ & $3,90 \pm 0,10$ & \\
\hline & \multicolumn{2}{|c|}{$3,87 \pm 0,06$} & \multicolumn{3}{|c|}{$4,37 \pm 0,05$} & \multicolumn{3}{|c|}{$2,88 \pm 0,06$} & \multicolumn{2}{|c|}{$4,18 \pm 0,07$} & \\
\hline
\end{tabular}




\subsection{Discusión}

El género Fusarium es uno de los hongos más importantes que causan pérdidas económicas en los cultivos en todo el mundo, por lo que el conocimiento acerca de su interacción es una clave importante para encontrar prácticas que disminuyan sus efectos negativos. En este trabajo de tesis, se demostró que Fusarium graminearum es una especie colonizadora de las raíces de Brachypodium distachyon. Peraldi et al. (2011) demostraron que esta especie puede infectar una gran variedad de tejidos de $B$. distachyon, incluidos coleóptiles, raíces, hojas y flores. En este estudio, esta especie de Fusarium ocasionó importantes valores de necrosis en los distintos ecotipos de $B$. distachyon, lo que demuestra que esta planta modelo sería adecuada para los estudios de la interacción entre F. graminearum y su hospedante. F. pseudograminearum, una especie estrechamente relacionada con $F$. graminearum, ocasionó síntomas de necrosis en las raíces de $B$. distachyon similares a las observadas con F. graminearum. Cabe destacar que ambas especies son potenciales productoras de DON. Varios investigadores han encontrado una relación estrecha entre la agresividad de un aislamiento y su producción de DON (Mesterhàzy et al., 1999, Mesterhàzy et al., 2002, Malbrán et al, 2014). Esta situación podría estar vinculada con lo observado en los estudios con la planta modelo B. distachyon.

Fusarium cerealis y $F$. poae ocasionaron necrosis en las raíces de 
Brachypodium distachyon menos notorias que las especies antes mencionadas. Ambas especies son potenciales productoras de NIV y esto puede explicar en parte estos resultados, aunque sería oportuno analizar la real producción de micotoxinas para confirmarlo. Miedaner et al. (2000) informaron que aislamientos de $F$. graminearum productores de DON fueron generalmente más agresivos que los productores de NIV, aunque las diferencias no fueron estadísticamente significativas. Goswani y Kistler (2005) encontraron una correlación significativa entre la cantidad de tricotecenos producidos por cada aislamiento y su nivel de agresividad en el trigo. En B. distachyon, Pasquet et al. (2016) mostraron que las raíces tratadas con DON presentaron mayor susceptibilidad en comparación con aquellas sin DON. Por lo tanto, sugirieron que la micotoxina es un importante factor de virulencia para el hongo, no solo para colonizar los tejidos de la planta, sino también para la infección primaria. Debido a sus resultados, se especula que las diferencias observadas entre los aislamientos y las raíces de $B$. distachyon podrían explicarse por la capacidad de estos de producir diferentes micotoxinas y/o cantidades de las mismas.

Se observaron diferencias en la agresividad hacia las raíces de Brachypodium distachyon entre los aislamientos de cada especie de Fusarium. El aislamiento de Fusarium graminearum 107-18 FG fue el más agresivo, mientras que los aislamientos 34-15 FG y 102-43 FG fueron significativamente menos agresivos. Se encontraron diferencias similares en la agresividad entre los aislamientos de $F$. pseudograminearum y F. poae. Estos resultados indicarían que las raíces de $B$. 
distachyon podrían usarse para examinar las posibles diferencias entre la interacción de esta planta y distintos aislamientos de Fusarium.

La interacción de Fusarium con sus hospedantees se ha evaluado utilizando diversos sistemas. Los estudios más clásicos se han centrado en la evaluación de la incidencia de especies de Fusarium en tejidos florales como indicador de agresividad (Alvarez et al., 2010; Malbrán et al., 2012). Sin embargo, este sistema tiene importantes desventajas ya que consume mucho tiempo y es muy laborioso. Por otro lado, los estudios de interacción pueden verse muy influenciados por el entorno donde se desarrolla el ensayo y por el método de inoculación que se utiliza (inoculación por punto o por aspersión en tejido floral o inoculación de la raíz por slurry, como en este estudio). Por ejemplo, en condiciones de campo hay muchos factores que no se pueden controlar, como plagas, temperatura, viento y lluvia que pueden afectar los resultados. Sin embargo, en condiciones de cámara, estos factores abióticos y bióticos están estrictamente controlados (Purahong et al., 2012).

La utilización de plantas modelo como herramientas en estudios de interacción entre plantas y patógenos es tan importante como necesaria. Este tipo de ensayos permite aproximarse a conocimientos acerca de una interacción determinada donde las pruebas necesarias presentan costos elevados, altas complejidades y tiempos prolongados. En contraposición, la utilización de plantas modelo depende de características como ciclo de vida corto, sistema de reproducción autógamo, porte pequeño y facilidad de identificación de las diferentes 
etapas del desarrollo biológico de la misma. El uso de Brachypodium distachyon como modelo está, día a día, más implementado en estudios de especies de la familia Poaceae por su mayor proximidad a los cereales de invierno que Arabidopsis thaliana. Por ejemplo, Goddard et al. (2014) evaluaron el impacto de la mutación de brasinoesteroides en plántulas, raíces y flores de $B$. distachyon contra varios patógenos fúngicos y observaron que era similar a los observados en la cebada.

En este estudio, resultó adecuado el uso de Brachypodium distachyon para evaluar la interacción con Fusarium en raíces por varios aspectos. Por un lado, el empleo de este organismo resultó sencillo, práctico y accesible, en cuanto a los materiales utilizados. La inoculación de las raíces fue efectiva, a través de la cual fue posible la visualización de síntomas y, de esta manera, la medición de necrosis a lo largo del tiempo estudiado. Por último, el tiempo necesario para llevar a cabo el ensayo resultó considerablemente corto, lo que permitió que la puesta a punto sea ágil y sencilla. Por lo tanto, se concluyó que la utilización de $B$. distachyon para este trabajo fue efectiva, de manera similar a los resultados obtenidos por Draper et al. (2001), los que sugirieron que esta planta es un hospedante útil para futuros estudios sobre la biología molecular y la genética de interacciones planta-patógeno. 


\section{CAPÍTULO V:}

\section{Conclusiones y}

\section{perspectivas finales}




\subsection{Conclusiones}

Las hipótesis formuladas para llevar a cabo este estudio fueron "La población de Fusarium es heterogénea a nivel de especie y por lo tanto en su potencial y producción de toxinas en los granos de cebada" y "Diferentes ecotipos de la planta modelo Brachypodium distachyon interactúan de diferente manera con distintas especies de Fusarium y entre distintos aislamientos de una misma especie". Ambas hipótesis planteadas se aceptaron con el desarrollo de los objetivos específicos y las técnicas utilizadas para realizarlos fueron adecuadas.

Los ensayos para aceptar la primera hipótesis demostraron, por un lado, que los granos de cebada en Argentina son colonizados por varias especies de Fusarium, principalmente F. graminearum y F. poae. Por otro lado, los granos tenían altas concentraciones de micotoxinas, específicamente DON y NIV, dos toxinas asociadas a las especies de Fusarium aisladas con mayor frecuencia. Cabe destacar, la importancia de ambas toxinas a nivel toxicológico y a nivel alimenticio. Este sería el primer trabajo que explora en profundidad la diversidad de especies de Fusarium y la concentración de toxinas en cebada cultivada en las principales zonas productoras del país.

El ensayo de interacción demostró, en principio, que Brachypodium distachyon es un hospedante adecuado para estudiar el comportamiento de 
distintas especies de Fusarium. También demostró la capacidad de Fusarium de infectar las raíces de dicha planta modelo. Por último, se pudo observar que en general, de las dos especies mayormente aisladas de los granos de cebada, los aislamientos de F. graminearum produjeron más síntomas que los de F. poae.

En el contexto mundial, donde el consumo de granos de cereales aumenta continuamente, existe una mayor dependencia de la importación de los países en desarrollo. Por lo tanto, existe un potencial real, tanto para los exportadores nuevos como para los tradicionales, a fin de remediar este desequilibrio. Pero los problemas asociados de seguridad alimentaria y degradación ambiental deben resolverse primero. Con respecto a la inocuidad de los alimentos, es esencial tener en cuenta las buenas prácticas agrícolas, el saneamiento de materias primas y la conservación de los recursos naturales, especialmente los renovables sobre los no renovables.

La información generada en esta tesis proporciona, por primera vez, datos esenciales sobre las especies de Fusarium y las toxinas asociadas con los granos de cebada en Argentina y, por lo tanto, contribuye al desarrollo futuro de estrategias de manejo sustentables, como lo es el manejo de agentes patógenos de manera responsable y teniendo en cuenta el impacto ambiental, el saneamiento de cultivos contaminados y de maquinaria empleada para la producción y la elaboración de subproductos del cereal, la rotaciones de los cultivos y el control de toxinas en la producción de cebada.

Fusarium altera la calidad de los granos de los cereales infectados así como 
los productos generados con los mismos, pero la principal preocupación con respecto a la aparición de especies de Fusarium en granos de cebada es que las micotoxinas que produce son perjudiciales para la salud de los humanos y animales. En este trabajo, se identificaron las principales especies de Fusarium que afectan los granos de cebada en Argentina y se documentó la presencia de un alto porcentaje de muestras con concentraciones elevadas de DON y de NIV. Además, se detectaron muestras que contenían ambas toxinas. Por lo tanto, es sumamente importante que los límites de concentración máxima permitida de estas dos toxinas se establezcan para granos de cebada y otros cereales en Argentina lo antes posible, así como a nivel mundial.

Si bien se observó variabilidad en la respuesta planta-patógeno entre los distintos ecotipos utilizados para este estudio, el uso de esta planta como modelo arrojó resultados interesantes. Por otro lado, esta es la primera vez que se demostró que Fusarium poae, F. cerealis y F. pseudograminearum se capaces de causar síntomas en las raíces de Brachypodium. En conclusión, la evaluación de las raíces de B. distachyon demostró ser un sistema eficiente, rápido y confiable para estudiar la interacción de los aislamientos de Fusarium. 


\subsection{Perspectivas finales}

Los datos obtenidos en este trabajo de tesis abren un panorama para iniciar la comprensión de principios agroecológicos del género Fusarium, tanto en la diversidad de especies presentes en granos de cebada en Argentina como en la vinculación de cada especie con su hospedante. Por un lado, los ensayos de presencia de micotoxinas en los granos de cebada esclarecen el efecto negativo de este patógeno frente a la inocuidad de los granos, así también como la importancia de la necesidad de regulación estricta para evitar consecuencias en los consumidores de los mismos.

Por otro lado, los estudios de Fusarium - Brachypodium proponen un sistema de trabajo óptimo para la evaluación de interacción del hongo. Sin embargo, sería necesario evaluar la susceptibilidad de otros órganos vegetales frente a estos patógenos. Por ejemplo, la generación de síntomas y la producción de toxinas en los granos de Brachypodium por las especies de Fusarium aquí estudiadas. Esto además, permitiría estudiar la presencia de genes involucrados en la respuesta a esta interacción planta - patógeno. Además, sería interesante evaluar la correlación de estos resultados con ensayos a campo utilizando cebada como hospedante, teniendo en cuenta la variabilidad por la presencia de factores bióticos y abióticos. 
REFERENCIAS

BIBLIOGRÁFICAS 
Abramoff, M.D., P.J. Magelhaes \& S.J. Ram. 2004. Image processing with ImageJ. Biophotonics Intenational 11: 36-42.

Agencia Nacional de Vigilancia Sanitaria. RDC no. 138. Disposición sobre límites máximos tolerados (LMT) para micotoxinas. Diario Oficial de la Unión, 9 de febrero de 2017.

Agrios G.N. 1999. Fitopatología. Limusa S.A. México. ISBN: 968-18-5184-6.

Altschul, S.F., W. Gish, W. Miller, E.W. Myers \& D.J. Lipman. 1990. Basic local alignment search tool. Journal of Molecular Biology 215: 403-410.

Álvarez, C.A., M.P. Azcarate \& V. Fernández Pinto. 2009. Toxigenic potential of Fusarium graminearum sensu stricto isolates from wheat in Argentina. International Journal of Food Microbiology 135: 131-135.

Alvarez, C.L., S. Somma, A. Moretti \& V. Fernández Pinto. 2010. Aggressiveness of Fusarium graminearum sensu stricto isolates in wheat kernels in Argentina. Journal of Phytopathology 158: 173-181.

Alvarez, C.L., S. Somma, R.H. Proctor, G. Stea, G. Mulè, A.F. Logrieco, V. Fernández Pinto \& A. Moretti. 2011. Genetic diversity in Fusarium graminearum from a major wheat-producing region of Argentina. Toxins 3: 1294-1309.

Angelotti, F., D.J. Tessmann, T.C. Alburquerque, J.B. Vida, D.S.J. Filho \& R. Harakava. 2006. Caracterização morfológica e identificação molecular de isolados de 
Fusarium graminearum associados à giberela do trigo e triticale no sul do Brasil. Summa Phytopathologica 32: 177-9.

Aoki, T., T.J. Ward, H.C. Kistler \& K. O’Donnell. 2012. Systematics, phylogeny and trichothecene mycotoxin potential of Fusarium head blight cereal pathogens. Mycotoxins 62: 91-102.

Astolfi, P., J. dos Santos, L. Schneider, L.B. Gomes, C.N. Silva, D.J. Tessmann \& E.M. Del Ponte. 2011. Molecular survey of trichothecene genotypes of Fusarium graminearum species complex from barley in Southern Brazil. International Journal of Food Microbiology 148: 197-201.

Astolfi, P., M.M. Reynoso, M.L. Ramírez, S.N. Chulze, T.C.A Alves, D.J. Tessmann \& E.M. Del Ponte. 2012. Genetic population structure and trichothecene genotypes of Fusarium graminearum isolated from wheat in southern Brazil. Plant Pathology 61: 289-295.

Audenaert, K., R. Van Broeck, B. Bekaert, F. De Witte, B. Heremans, K. Messens, M. Höfte \& G. Haesaert. 2009. Fusarium head blight (FHB) in Flanders: population diversity, inter-species associations and DON contamination in commercial winter wheat varieties. European Journal of Plant Pathology 125: 445458.

Baldanzi, G., A.C. Baier, E.L. Floss, W. Manara, N.T. Felkl Manara, P. Veira \& M.F.S. Tarrag. 1988. As lavouras de inverno 2. Rio de Janeiro: Globo. Pp 16-67. 
Beccari, G., L. Caproni, F. Tini, S. Uhlig \& L. Covarelli. 2016. Presence of Fusariumspecies and other toxigenic fungi in malting barley and multi-mycotoxin analysis by liquid chromatography-high-resolution mass spectrometry. Journal of Agricultural and Food Chemistry 64: 4390-4399.

Beccari, G., A. Prodi, F. Tini, U. Bonciarelli, A. Onofri, S. Oueslati, M. Limayma \& L. Covarelli. 2017. Changes in the Fusarium head blight complex of malting barley in a three-year field experiment in Italy. Toxins 9(4): 120.

Blümke, A., B. Sode, D. Ellinger \& C.A. Voigt. 2015. Reduced susceptibility to Fusarium head blight in Brachypodium distachyon through priming with the Fusarium mycotoxin deoxynivalenol. Molecular Plant Pathology 16(5): 472-483.

Bolsa de Comercio de Rosario. 2018. Los stocks mundiales de cebada en mínimos de 23 años. Informativo semanal del 19 de octubre de 2018. Disponible en: https://bcr.com.ar/es/mercados/investigacion-y-desarrollo/informativosemanal/noticias-informativo-semanal/los-stocks

Bourdages, J.V., S. Marchand, S. Rioux \& F.J. Belzile. 2006. Diversity and prevalence of Fusarium species from Quebec barley fields. Canadian Journal of Plant Pathology 28: 419-425.

Brown, W.M., M. George Jr. \& A.C. Wilson. 1979. Rapid evolution of animal mitochondrial DNA. Proceeding of the National Academy of Sciences of the United States of America 76: 1967-1971. 
Bruns, T.D. \& T.M. Szaro. 1992. Rate and mode differences between nuclear and mitochondrial small-subunit rRNA genes in mushrooms. Molecular Biology and Evolution 9: 836-855.

Campbell, C.L. \& L.V. Madden. 1990. Introduction to Plant Disease Epidemiology. Wiley, New York.

Castañares E., S.A. Stenglein, M.I. Dinolfo \& M.V. Moreno. 2011. Fusarium tricinctum associated with Head Blight on wheat in Argentina. Plant Disease 95: 496.

Castañares, E., L. Wehrhahne \& S.A. Stenglein. 2012. Fusarium pseudograminearum associated with barley kernels in Argentina. Plant Disease 96: 763.

Castañares, E., M.I. Dinolfo, M.V. Moreno, C. Berón \& S.A. Stenglein. 2013. Fusarium cerealis Associated with Barley Seeds in Argentina. Journal of Phytopathology 161: 586-589.

Castañares, E., D. Ramirez Albuquerque, M.I. Dinolfo, V. Fernandez Pinto, A. Patriarca \& S.A. Stenglein. 2014. Trichothecene genotypes and production profiles of Fusarium graminearum isolates obtained from barley cultivated in Argentina. International Journal of Food Microbiology 179: 57-63.

Castañares, E., M.I. Dinolfo, E.M. Del Ponte, D. Pan \& S.A. Stenglein. 2016. Species composition and Genetic structure of Fusarium graminearum species 
complex populations affecting the main barley growing regions of South America. Plant Pathology 65: 930-939.

Cebada cervecera. 2019 Disponible en: https://www.cebadacervecera.com.ar/. Última consulta Junio 2019.

Centro de Información oficial, Normativa y Avisos Legales del Uruguay. Reglamento técnico MERCOSUR sobre límites máximos de Aflatoxinas admisibles en leche maní y maíz. 31 de mayo de 2006.

Chandler, E., D. Simpson, M. Thomsett \& P. Nicholson. 2003. Development of a PCR assays to Tri7 and Tri13 trichothecene biosynthetic genes, and characterisation of chemotypes of Fusarium graminearum, Fusarium culmorum and Fusarium cerealis. Physiological and Molecular Plant Pathology 62: 355-367.

Chen, X., A. Steed, C. Harden \& P. Nicholson. 2006. Characterization of Arabidopsis thaliana-Fusarium graminearum interactions and identification of variation in resistance among ecotypes. Molecular Plant Pathology 7(5): 391-403.

Chen, X, A. Steed, S. Travella, B. Keller \& P. Nicholson. 2009. Fusarium graminearum exploits ethylene signaling to colonize dicotyledonous and monocotyledonous plants. New Phytologist 182: 975-983.

Chochois, V., J.P. Vogel \& M. Watt. 2012. Application of Brachypodium to the genetic improvement of wheat roots. Journal of Experimental Botany 63: 3467-3474. 
Choi, C.Y., H. Nakajima-Adachi, S. Kaminogawa \& Y. Sugita-Konishi. 2002. Nivalenol Inhibits Total and Antigen-Specific IgE Production in Mice. Toxicology and Applied Pharmacology 165: 94-98.

Cirillo, T., A. Ritieni, M. Visone \& R. Arnodiococchieri. 2003. Evaluation of conventional and organic Italian foodstuffs for Deoxynivalenol and Fumonisins $\mathrm{BI}$ and 82. Journal of Agricultural and Food Chemistry 51(27): 28-31.

Comisión Europea. 1999. Evaluating socio-economic programmes: glossary of 300 concepts and technical terms, Luxemburgo: Oficina de publicaciones Oficiales de las comunidades Europeas. European Mycotoxin Awareness Network: http:/lwww.mycotoxins.org.

Comisión del Codex Alimentarius. 2011. Programa conjunto FAO/OMS sobre normas alimentarias. Comité del codex sobre contaminantes de los alimentos. Anteproyecto de niveles máximos para el deoxinivalenol (DON) y sus derivados acetilados en los cereales y productos a base de cereales (N10-2010). Quinta reunión, 21-25 de Marzo del 2011.

Comisión del Codex Alimentarius. 2013. Programa conjunto FAO/OMS sobre normas alimentarias. Comité del codex sobre contaminantes de los alimentos. Séptima reunión, 8-12 de Abril del 2013. ftp://ftp.fao.org/codex/Meetings/cccf/cccf7/cf07_07_Add1s.pdf. 
Covarelli, L., G. Beccari, A. Prodi, S. Generotti, F. Etruschi, C. Juan, E. Ferrer \& J. Manes. 2015. Fusarium species, chemotype characterization and trichothecene contamination of durum and soft wheat in an area of central Italy. Journal of the Science of Food and Agricultural 95: 540-551.

Dangl, J.L. 1993. Application of Arabidopsis thaliana to outstanding issues in plant-pathogen interactions. International Review of Cytology 144: 53-83.

Del Ponte, E.M., P. Spolti, T.J. Ward, L.B. Gomes, C.P. Nicolli, P.R. Kuhnem, C.N. Silva \& D.J. Tessmann. 2015. Regional and field-specific factors affect the composition of Fusarium head blight pathogens in subtropical no-till wheat agroecosystem of Brazil. Phytopathology 105: 246-254.

Desjardins, A.N., T.M. Hohn, \& S.P. McCormick. 1993. Trichothecene Biosynthesis in Fusarium Species: Chemistry, Genetics, and Significance. American Society for Microbiology 57(3): 595-604.

Desjardins, A.E. 2006. Fusarium Mycotoxins Chemistry, Genetics and Biology; American Phytopathological Society Press: St. Paul, MN, USA.

\section{Desmond, O.J., C.I. Edgar, J.M. Manners, D.J. Maclean, P.M. Schenck \& K.}

Kazan. 2006. Methyl jasmonate induced gene expression in wheat delays symptom development by the crown rot pathogen Fusarium psedograminearum. Physiological and Molecular Plant Pathology 67: 171-179. 
Dinolfo M.I., S.A. Stenglein, M.V. Moreno, P. Nicholson, P. Jennings \& G.L. Salerno. 2010. ISSR markers detect high genetic variation among Fusarium poae isolates from Argentina and England. European Journal of Plant Pathology 127: 483491.

Dinolfo, M.I., G.G. Barros \& S.A. Stenglein. 2012. Development of a PCR assay to detect the potential production of nivalenol in Fusarium poae. FEMS Microbiology Letters 332: 99-104.

Dinolfo, M.I. \& S.A. Stenglein. 2014. Fusarium poae and mycotoxins: potential risk for consumers. Boletín de la Sociedad Argentina de Botánica 49: 5-20.

Dinolfo, M.I., E. Castañares \& S.A. Stenglein. 2017. Resistance of Fusarium poae in Arabidopsis leaves requires mainly functional JA and ET signaling pathways. Fungal Biology 121 (10): 841-848.

Doyle, J.J. \& J.L. Doyle. 1990. Isolation of plant DNA from fresh tissue. Focus 12: $13-15$.

Draper, J., L.A.J. Mur, G. Jenkins, G.C. Ghosh-Biswas, P. Bablak, R. Hasterok R \& A.P.M. Routledge. 2001. Brachypodium distachyon a new model system for functional genomics in grasses. Plant Physiology 127: 1539-1555.

D'Mello, J.P.F., C.M. Placinta \& A.M.C. Macdonald. 1999. Fusarium mycotoxins: A review of global implications for animal health, welfare and productivity. Animal Feed Science and Technology 80: 183-205. 
Ehling, G., A. Cockburn, P. Snowdon \& H. Buschhaus. 1997. The significance of the Fusarium toxin deoxynivalenol (DON) for human and animal health. Cereal Research Communications 25: 443-447.

Eriksen, G.S. 2003. Metabolism and Toxicity of Trichothecenes. Disponible en: http://pub.epsilon.slu.se/287/1/Thesis.pdf. Última consulta mayo 2019.

Fernández Pinto, V., A. Patriarca \& G. Pose. 2013. Mycotoxins associated to Fusarium species that caused Fusarium Head Blight in wheat in Latin-America. Disponible en: Fusarium Head Blight in Latin America. Pp. 59-73.

Forsell, J. \& J. Petska. 1985. Relation of 8-ketotrichothecene and Zearalenone analog structure to inhibition of mitogen-induced human lymphocyte blastogenesis. Applied and Environmental Microbiology 50: 1304-1307.

Fredlund, E., A. Gidlund, M. Sulyok, T. Börjesson, R. Krska \& M. Olsen. 2013. Deoxynivalenol and other selected Fusarium toxins in Swedish oats - occurrence and correlation to specific Fusarium species. International Journal of Food Microbiology 167: $276-283$.

Galizio, R. 2010. Ocurrencia y caracterización de especies del género Fusarium en granos de cereales. Tesis de grado Licenciatura en Tecnología de los Alimentos. Facultad de Agronomía. UNCPBA.

Gargouri, S., I. Mtat, L.G. Kammoun, M. Zid \& R. Hajlaoui. 2011. Molecular genetic diversity in populations of Fusarium pseudograminearum from Tunisia. 
Journal of Phytopathology 159: 306-313.

Geiser, D. M., M. Jiménez-Gasco, S. Kang, I. Makalowska, N. Veeraraghavan, T.J. Ward, et al. 2004. FUSARIUM-ID v.1.0: A DNA sequence database for identifying Fusarium. European Journal of Plant Pathology 110: 473-479.

Gergerich, R.C. \& V.V. Dolja. 2006. Introduction to plant viruses, the invisible foe. The Plant Health Instructor.

Goddard, R., A. Peraldi, C. Ridout \& P. Nicholson. 2014. Enhanced Disease Resistance Caused by BRI1 Mutation is Conserved Between Brachypodium distachyon and Barley (Hordeum vulgare). Molecular Plant-Microbe Interactions 27: 1095-1106.

Goswami, R.S. \& H.C. Kistler. 2005. Pathogenicity and in planta mycotoxin accumulation among members of the Fusarium graminearum species complex on wheat and rice. Phytopathology 95(12): 1397-1404.

Hall, T.A. 1999. BioEdit: a user-friendly biological sequence alignment editor and analysis program for Windows 95/98/NT. Nucleic Acids Symposium Series 41: 95-98.

Hazel, C.M. \& I.S. Pate. 2004. Influence of processing on trichothecene levels. Toxicology Letter 153 (I): 51-57.

Hofgaard, I.S., H.U. Aamot, T. Torp, M. Jestoi, V.M.T. Lattanzio, S.S. Klemsdal, C. Waalwijk, T. Van der Lee, G. Brodal. 2016. Association between Fusarium species 
and mycotoxins in oats and spring wheat from farmers field in Norway over a six year period. World Mycotoxin Journal 9: 365-378.

Ibarguren, L. 2014 Cebada (Hordeum vulgare). http://campus.fca.uncu.edu.ar/pluginfile.php/22767/mod_resource/content/0/Ceba da.pdf. Última consulta Mayo 2019.

International Brachypodium Initiative (IBI). 2010. Genome sequencing and analysis of the model grass Brachypodium distachyon. Nature 463: 763-768.

Jurado, M., C. Vásquez, B. Patiño \& M.T. González-Jaél. 2005. PCR detection assays for the trichothecene-producing species Fusarium graminearum, Fusarium culmorum, Fusarium poae, Fusarium equiseti and Fusarium sporotrichioides. Systematic and Applied Microbiology 28(1): 561-568.

Karlsson, I., H. Friberg, A.K Kolseth, C. Steinberg \& P. Persson. 2017. Agricultural factors affecting Fusarium communities in wheat kernels. International Journal of Food Microbiology 252: 53-60.

Kaur, M., J.P. Bowman, D.C. Stewart \& D.E. Evans. 2015. The fungal community structure of barley malts from diverse geographical regions correlates with malt quality parameters. International Journal of Food Microbiology 215: 71-78.

Kind, S., S. Schurack, J. Hinsch \& P. Tudzynski. 2018. Brachypodium distachyon as an alternative model host system for the ergot fungus Claviceps purpurea. Molecular Plant Pathology in press 19: 1005-1011. 
Koopmann, B., P. Karlovsky \& G. Wolf. 1994. Differentiation between Fusarium culmorum and Fusarium graminearum by RFLP and with species-specific DNA probes. En: Schots, A., F.M. Dewey \& R. Oliver. Modern Assays for Plant Pathogenic Fungi, Identification, Detection and Quantification. Wallingford, UK. Centre for Agricultural Bioscience International. Pp 37-46

Kristensen, R., M. Torp, B. Kosiak \& A. Holst-Jensen. 2005. Phylogeny and toxigenic potential is correlated in Fusarium species as revealed by partial translation elongation factor $1 \alpha$ gene sequences. Mycological Research 109:173-186.

Kulik, T. 2008. Detection of Fusarium tricinctum from cereal grain using PCR assay. Journal of applied genetics 49(3): 305-311.

Lamprecht, S.C., W.F.O. Marasas, M.B. Hardy \& F.J. Calitz. 2006. Effect of crop rotation on crown rot and the incidence of Fusarium pseudograminearum in wheat in the Western Cape, South Africa. Australasian Plant Pathology 35: 419-426.

Leslie, J.F. \& B.A. Summerell. 2006. The Fusarium laboratory manual. Oxford, Blackwell.

Logrieco, A., A. Bottalico, G. Mule, A. Moretti \& G. Perrone. 2003. Epidemiology of toxigenic fungi and their associated mycotoxins for some Mediterranean crops. European Journal of Plant Pathology 109: 645-67. 
Lori, G.A \& I. Rino. 2007. Deoxinivalenol. En Micotoxinas en alimentos. Director-Coordinador: Soriano del Castillo, J.M. Ediciones Díaz de Santos. España. Pp 396.

Malbrán, I., C.A. Mourelos, J.R. Girotti, M.B. Aulicino, P.A. Balatti \& G.A. Lori. 2012. Aggressiveness variation of Fusarium graminearum isolates from Argentina following point inoculation of field grown wheat spikes. Crop Protection 42: $234-243$.

Malbrán, I., C.A. Mourelos, J.R. Girotti, P.A. Balatti \& G.A. Lori. 2014. Toxigenic capacity and trichothecene production by Fusarium graminearum isolates from Argentina and their relationship with aggressiveness and fungal expansion in the wheat spike. Phytopathology 104: 357-364.

Manning, B, R. Southwell, P. Hayman \& K. Moore. 2000. Fusarium Head Blight in Northern NSW. NSW Agriculture in Research Update. New South Wales. Agdex 110/637.

Martínez, M., E. Castañares, M.I. Dinolfo, W.G. Pacheco, M.V. Moreno \& S.A. Stenglein. 2014. Presencia de Fusarium graminearum en muestras de trigo destinado al consumo humano. Revista Argentina de Microbiología 46: 41-44.

Marzocco, S., R. Russo, G. Bianco, G. Autore \& L. Severino. 2009. Proapoptotic effects of nivalenol and deoxynivalenol trichothecenes in J774A.1 murine macrophages. Toxicology Letters 189: 21-26. 
McMullen, M., R. Jones \& D. Gallenberg. 1997. Scab of wheat and barley: A re-emerging disease of devastating impact. Plant Disease 81: 1340-1348.

Mesterházy, A., \& T. Bartók. 1996. Control of Fusarium head blight of wheat by fungicides and its effect on the toxin contamination of the grains. PflanzenschutzNachrichten Bayer 49: 181-198.

Mesterházy, A., T. Bartók, C.M. Mirocha \& R. Komoróczy. 1999. Nature of resistance of wheat to Fusarium head blight and deoxynivalenol contamination and their consequences for breeding. Plant Breeding 118: 97-110.

Mesterházy, A. 2002. Role of deoxynivalenol in aggressiveness of Fusarium graminearum and F. culmorum and in resistance to Fusarium head blight. European Journal of Plant Pathology 108: 675-684.

Miedaner, T., C. Reinbrecht \& A.G. Schilling. 2000. Association among aggressiveness, fungal colonization, and mycotoxin production of 26 isolates of Fusarium graminearum in winter rye head blight. Journal of Plant Diseases and Protection 107: 124-34.

Mishra, P.K., R.T.V. Fox \& A. Culham. 2003. Development of a PCR-based assay for rapid and reliable identification of pathogenic Fusaria. FEMS Microbiology Letters 218: 329-332.

Monds, R.D., M.G. Cromey, D.R. Lauren, M. di Menna \& J. Marshall. 2005. F. graminearum, F. cortaderiae and F. pseudograminearum in New Zealand: molecular 
phylogenetic analysis, mycotoxin chemotypes and co-existence of species. Mycological Research 109: 410-420.

Moss, M.O. 1989. Mycotoxins of Aspergillus and other filamentous fungi. Journal of Applied Bacteriology 67: 69-81.

Mulé, G., A. Susca, G. Stea \& A. Moretti. 2004. A species-specific PCR assay based on the calmodulin partial gene for the identification of Fusarium verticillioides, F. proliferatum and F. subglutinans. European Journal of Plant Pathology 110: 495502.

Mûller, E. \& W. Loeffler. 1976. Mycology. An outline for science and medical students. Stuttgart, Germany. Thieme Publishers. Página 15

Nelson, P.E., T.A. Toussoun \& W.F.O. Marasas. 1983. Fusarium species: an illustrated manual for identification. Pennsylvania State University Press, University Park, Pennsylvania.

Nicholson, P., D.R. Simpson, G. Weston, H.N. Rezanoor, A.K. Lees, D.W. Parry \& D. Joyce. 1998. Detection and quantification of Fusarium culmorum and Fusarium graminearum in cereals using PCR assays. Physiological and Molecular Plant Pathology 53: 17-37.

Nicholson, P., E. Chandler, R.C. Draeger, N.E. Gosman, D.R Dimpson \& M. Thomsett. 2003. Molecular tools to study epidemiology and toxicology of Fusarium head blight of cereals. European Journal of Plant Pathology 109: 691-703. 
Nielsen, L.K., J.D. Jensen, G.C. Nielsen, J.E. Jensen, N.H. Spliid, I.K. Thomsen, A.F. Justesen, D.B. Collinge \& L.N. Jørgensen. 2011. Fusarium head blight of cereals in Denmark: species complex and related mycotoxins. Phytopathology 101: 960-969.

Nielsen, L.K., D.J. Cookb, S.G. Edward \& R.V. Ray. 2014. The prevalence and impact of Fusarium head blight pathogens and mycotoxins on malting barley quality in UK. International Journal of Food Microbiology 179: 38-49.

Nogueira, M.S., J. Decundo, M. Martinez, S.N. Dieguez, F. Moreyra, M.V. Moreno \& S.A. Stenglein. 2018. Natural Contamination with Mycotoxins produced by Fusarium graminearum and Fusarium poae in Malting Barley in Argentina. Toxins 10: 78.

Noots, I., J. Delcour \& C. Michiels. 1999. From field barley to malt: detection and specification of microbial activity for quality aspects. Critical Reviews in Microbiology 25: 121-153.

Omurtag, G.Z. \& D. Beyoglu. 2007. Occurrence of deoxynivalenol (vomitoxin) in beer in Turkey detected by HPLC. Food Control 18: 163-166.

Osborne, L.E. \& J.M. Stein. 2007. Epidemiology of Fusarium head blight on small-grain cereals. International Journal of Food Microbiology. 119: 103-108.

Ouellet, T. \& K.A. Siefert. 1993. Genetic characterization of Fusarium graminearum strains using RAPD and PCR amplification. Phytopathology 83: 10031007. 
O'Donnell, K., H.C. Kistler, E. Cigelnik, R.C. Ploetz. 1998. Multiple evolutionary origins of the fungus causing Panama disease of banana: concordant evidence from nuclear and mitochondrial gene genealogies. Proceeding of the National Academy of Sciences of the United States of America 95: 2044-2049.

Pan, D., F. Bonsignore, F. Rivas, G. Perera \& L. Bettucci. 2007. Deoxynivalenol in barley samples from Uruguay. International Journal of Food Microbiology 114: 149-152.

Pan, D., N. Calero, A. Mionetto \& L. Bettucci. 2013. Trichothecene genotypes of Fusarium graminearum from wheat in Uruguay. International journal of Food Microbiology 162: 120-123.

Parry, D.W., P. Jenkinson \& L. McLeod. 1995. Fusarium ear blight (scab) in small grain cereals- a review. Plant Pathology 44: 207-238.

Parry, D.W. \& P. Nicholson. 1996. Development of a PCR assay to detect Fusarium poae in wheat. Plant Pathology 45: 383-391.

Pasquet, J.C., S. Chaouch, C. Macadré, S. Balzergue, S. Huguet, M.L. MartinMagniette, F. Bellvert, X. Deguercy, V. Thareau, D. Heinzt, P. Saindrenan \& M. Dufresne. 2014 Differential gene expression and metabolomic analyses of Brachypodium distachyoninfected by deoxynivalenol producing and non-producing strains of Fusarium graminearum. BMC Genomics 15: 629. 
Pasquet, J.C., V. Changenet, C. Macadré, E. Boex-Fontvieille, C. Soulhat, O. Bouchabké-Coussa, M. Dalmais, V. Atanasova-Pénichon, A. Bendahmane, P. Saindrenan \& M. Dufresne. 2016. A Brachypodium UDP-Glycosyltransferase confers root tolerance to deoxynivalenol and resistance to Fusarium infection. Plant Physiology 172(1): 559-574.

Peraldi, A., G. Beccari, A. Steed \& P. Nicholson. 2011. Brachypodium distachyon: a new pathosystem to study Fusarium Head Blight and other Fusarium diseases on wheat. BMC Plant Biology 11: 100.

Peraldi, A., L.L. Griffe, C. Burt, G.R.D. McGrann \& P. Nicholson. 2014. Brachypodium distachyon exhibits compatible interactions with Oculimacula spp. and Ramularia collo-cygni, providing the first pathosystem model to study eyespot and ramularia leaf spot diseases. Plant Pathology 63: 554-562.

Pestka, J.J. 2010. Toxicological mechanisms and potential health effects of deoxynivalenol and nivalenol. World Mycotoxin Journal 3: 323-347.

Piacentini, K.C., G.D. Savi, M.E.V. Pereira \& V.M. Scussel. 2015. Fungi and the natural occurrence of deoxynivalenol and fumonisins in malting barley (Hordeum vulgare L.). Food Chemistry 187: 204-209.

Pitt, J.I. 1996. ¿What are mycotoxins? Australian Mycotoxin Newsletter 7(4): $1-8$. 
Purahong, W., D. Alkadri, P. Nipoti, A. Pisi, M. Lemmens \& A. Prodi. 2012. Validation of a modified Petri-dish test to quantify aggressiveness of Fusarium graminearum in durum wheat. European Journal of Plant Pathology 132: 381-391.

Rahmani, A., S. Jinap \& F. Soleimany. 2009. Qualitative and quantitative analysis of mycotoxins. Comprehensive Reviews in Food Science and Food Safety. Disponible en: $\quad$ https://onlinelibrary.wiley.com/doi/pdf/10.1111/j.15414337.2009.00079.x

Reis, E. \& M. Carmona. 2002. Fusariosis del trigo: Biología, epidemiología y estrategias para su manejo. BASF Argentina S.A. Buenos Aires.

ReTAA. Relevamiento de Tecnología Agrícola Aplicada de la Bolsa de Cereales. 2019. Número 20.Disponible en: http://cebadacervecera.com.ar/cebada-informede-la-bolsa-de-cereales-de-la-campana-2018-19/

Reynoso, M.M., M.L. Ramírez, A.M. Torres \& Chulze S.N. 2011. Trichothecene genotypes and chemotypes in Fusarium graminearum strains isolated from wheat in Argentina. International Journal of Food Microbiology 145: 444-448.

Rotter, B., D.B. Prelusky \& J.J. Petska. 1996. Toxicology of deoxynivalenol (vomitoxin). Journal of Toxicology and Environmental Health 48: 1-34.

Sambrook, J, E.F. Fritschi \& T. Maniatis. 1989. Molecular cloning: a laboratory manual, Cold Spring Harbor Laboratory Press, New York. 
Sarver B.A.J., T.J. Ward, L.R. Gale, K. Broz, H.C. Kistler, T. Aoki, P. Nicholson, J. Carter \& K. O’Donnell. 2011. Novel Fusarium head blight pathogens from Nepal and Louisiana revealed by multilocus genealogical concordance. Fungal Genetics and Biology 48: 1096-1107.

Schmale, D.G., A.K. Wood-Jones, C. Cowger, G.C. Bergstrom \& C. Arellano. 2011. Trichothecene genotypes of Gibberella zeae from winter wheat fields in the eastern USA. Plant Pathology 60: 909-17.

Schneebeli, K., U. Mathesius \& M. Watt. 2015. Brachypodium distachyon is a pathosystem model for the study of the wheat disease rhizoctonia root rot. Plant Pathology 64: 91-100.

Schöneberg, T., C. Martinb, F. Wettsteina, T.D. Buchelia, F. Mascherb, M. Bertossab, T. Musaa, B. Kellerc \& S. Vogelgsang. 2016. Fusariumand mycotoxin spectra in Swiss barley are affected by various cropping techniques. Food Additives \& Contaminants: Part A 10: 1608-1619.

Schwarz, P.B. 2003. Impact of Fusarium head blight on malting and brewing quality of barley. In Fusarium Head Blight of Wheat and Barley; Leonard, K.J., Bushnell, W.R., Eds.; American Phytopathological Society Press: St. Paul, MN, USA. Pp 395-419.

Scoz, L.B., P. Astolfi, D.S. Reartes \& D.G. Schmale III, M.G. Morales \& E.M. Del Ponte. 2009. Trichothecene mycotoxin genotypes of Fusarium graminearum 
sensu stricto and Fusarium meridionale in wheat from southern Brazil. Plant Pathology 58: 344-351.

Silvestro, L. 2015. Ocurrencia, distribución y caracterización de hongos de suelo en sistemas agrícolas bajo siembra directa. Tesis de Doctorado en Ciencias, área Biología. Facultad de Ciencias Exactas y Naturales. Universidad Nacional de Mar del Plata.

Soriano del Castillo, J.M. 2007. Micotoxinas en alimentos. DirectorCoordinador: Soriano del Castillo, J.M. Ediciones Díaz de Santos. España. Pp 23.

Spanic, V., M. Lemmens \& G. Drazner. 2010. Morphological and molecular identification of Fusarium species associated with head blight on wheat in East Croatia. European Journal of Plant Pathology 128: 511-516.

Stenglein, S.A. \& P.A. Balatti. 2006. Genetic diversity of Phaeoisariopsis griseola in Argentina as revealed by virulence and molecular markers. Physiological and Molecular Plant Pathology 68: 158-167.

Stenglein S.A., M.I. Dinolfo, M.V. Moreno \& R. Galizio. 2010. Fusarium proliferatum, a new pathogen causing Head Blight on oat in Argentina. Plant Disease 94: 6 .

Trail, F. 2009. For blighted waves of grain: Fusarium graminearum in the postgenomics era. Plant Physiology 149(1): 103-110. 
Trucksess, M.W. \& D.E. Koeltzow. 1995. Evaluation and application of immunochemical methods for mycotoxins in food. In: Editores: Nelson J.O., A.E. Karu \& R.B. Wong. Immunoanalysis of Agrochemicals in Emerging Technologies, American Chemical Society, Washington, DC. Pp 326-334.

Ueno, Y. \& K. Fukushirna. 1968 Inhibition of protein and DNA syntesis in Ehrlich ascites tumor by nivalenol, a toxic principle of Fusarium nivale growing riceM. Experientia (Basel) 24: 1032-1033.

Umpierrez-Falaiche, M., G. Garmendia, S. Pereyra, A. Rodriguez Haralambides, T.J. Ward \& S. Vero. 2013. Regional differences in species composition and toxigenic potential among Fusarium head blight isolates from Uruguay indicate a risk of nivalenol contamination in new wheat production areas. International Journal of Food Microbiology 166: 135-140.

Urban. M., S. Daniels, E. Mott \& K. Hammond-Kosack. 2002. Arabidopsis is susceptible to the cereal ear blight fungal pathogen Fusarium graminearum and Fusarium culomorum. The Plant Journal 32: 961-973

Vogel, J.P., D.F. Garvin, T.C. Mockler, J. Schmutz, D. Rokhsar \& M.W. Bevan. 2010. Genome sequencing and analysis of the model grass Brachypodium distachyon. Nature 463: 763-768. 
Waalwijk, C., P. Kastelein, I. de Vries, Z. Kerényo, T. van der Lee, T. Hesselink, J. Köhl \& G. Lema. 2003. Major changes in Fusarium spp. in wheat in the Netherlands. European Journal of Plant Pathology 109: 743-754.

Wartha, B., M. Sulyoka, P. Fruhmannb, F. Berthillera, R. Schuhmachera, C. Hametnerb, G. Adamc, J. Fröhlichb \& R. Krskaa. 2012. Assessment of human deoxynivalenol exposure using an LC-MS/MS based biomarker method. Toxicology Letters 211: 85-90.

Williams, K.J., J.T. Dennis, C. Smyl \& H. Wallwork. 2002. The application of species-specific assays based on the polymerase chain reaction to analyze Fusarium crown rot of durum wheat. Australasian Plant Pathology 31: 119-127.

Wollenweber, H.W. \& O.A. Reinking. 1935. Die Fusarien, ihre Beschreibung, Schadwirkung und Bekampfung. Verlag Paul Parey, Berlin, Germany.

Xu, X.M, P. Nicholson, M.A. Thomsett, D. Simpson, B.M. Cooke, F.M. Doohan, J. Brennan, S. Monaghan, A. Moretti, G. Mule, L. Hornok, E. Beki, J. Tatnell, A. Ritieni \& S.G. Edwards. 2008. Relationship between the fungal complex causing Fusarium head blight of wheat and environmental conditions. Phytopathology 98: 69-78.

Yoder, W.T. \& L.M. Christianson. 1998. Species-specific primers resolve members of Fusarium section Fusarium. Fungal Genetics and Biology 23: 68-80. 
Yli- Mattila, T., S. Paavanen-Huhtala, S.A. Bulat, I.A. Alekhina \& H.I. Nirenberg. 2002. Molecular, morphological and phylogenetic analysis of Fusarium avenaceum/F. arthosporioides/F. tricinctum species complex - a polyphasic approach. Mycological Research 106: 655-669.

Yli-Mattila, T., S. Paavanen-Huhtala, M. Jestoi, P. Parikka, V. Hietaniemi, T. Gagkaeva, T. Sarlin, A. Haikara, S. Laaksonen \& A. Rizzo. 2008. Real-time PCR detection and quantification of Fusarium poae, F. graminearum, F. sporotrichioides and F. langsethiae in cereal grains in Finland and Russia. Archives of Phytopathology and Plant Protection 41: 243-260.

Zadoks, J.C., T.T. Chang \& C.F. Konzac. 1974. A decimal code for the growth stages of cereals. Weed Research 14: 415-421.

Zheng, Z., D. Houchins, J. Ung \& J.L. Richard. 2004. Validation of an ELISA test kit for the detection of deoxynivalenol in several food commodities. New Horizon of Mycotoxicology for Assuming Food Safety (Proceedings of ISMYCO Kagawa '03).

Zheng, M.Z, J.L. Richard \& J. Binder. 2006. A review of rapid methods for the analysis of mycotoxins. Mycopathologia 161: 261-273.

Zhong, S., S. Ali, Y. Leng, R. Wang \& D.F. Garvin. 2015. Brachypodium distachyon-Cochliobolus sativus pathosystem is a new model for studying plantpathogen interactions in cereal crops. Phytopathology 105: 482-489. 


\section{Publicaciones derivadas}


Parte de los resultados de esta tesis fueron publicados en revistas científicas con el objetivo de divulgar conocimiento y fomentar la investigación

- $\quad$ Nogueira M.S., Decundo J., Martinez M., Dieguez S.N., Moreyra F., Moreno M.V., Stenglein S.A., 2018. Natural contamination with mycotoxins produced by Fusarium graminearum and Fusarium poae in malting barley in Argentina. Toxins $2018,10,78$. 
Article

\title{
Natural Contamination with Mycotoxins Produced by Fusarium graminearum and Fusarium poae in Malting Barley in Argentina
}

María Soledad Nogueira ${ }^{1}$, Julieta Decundo ${ }^{2}$, Mauro Martinez ${ }^{1}$, Susana Nelly Dieguez ${ }^{2}$, Federico Moreyra ${ }^{3}$, Maria Virginia Moreno ${ }^{1,4}$ and Sebastian Alberto Stenglein $1,4, *$ (C)

1 Laboratorio de Biología Funcional y Biotecnología (BIOLAB), UNCPBA-CICBA, INBIOTEC-CONICET, Av. República de Italia 780, Azul, 7300 Buenos Aires, Argentina; solenogueira@gmail.com (M.S.N.); maurom@faa.unicen.edu.ar (M.M.); vmoreno@faa.unicen.edu.ar (M.V.M.)

2 Área de Toxicología, Departamento de Fisiopatología, Centro de Investigación Veterinaria de Tandil (CIVETAN) CONICET-CICBA, Facultad de Ciencias Veterinarias-UNCPBA, Campus Universitario, Paraje Arroyo Seco s/n, Tandil, 7000 Buenos Aires, Argentina; jdecundo@vet.unicen.edu.ar (J.D.); susadie@vet.unicen.edu.ar (S.N.D.)

3 Estación Experimental Agropecuaria INTA Bordenave, Ruta Provincial 76 Km 36,5, Bordenave, 8187 Buenos Aires, Argentina; moreyra.federico@inta.gob.ar

4 Área de Microbiología, Facultad de Agronomía de Azul-UNCPBA, Av. República de Italia 780, Azul, 7300 Buenos Aires, Argentina

* Correspondence: stenglein@faa.unicen.edu.ar; Tel.: +54-2281-433-291

Received: 30 October 2017; Accepted: 16 January 2018; Published: 11 February 2018

\begin{abstract}
Two of the most common species of toxin-producing Fusarium contaminating small cereal grains are Fusarium graminearum and F. poae; with both elaborating diverse toxins, especially deoxynivalenol (DON) and nivalenol (NIV), respectively. The objective of our work during the 2012-2014 growing seasons was to screen crops for the most commonly isolated Fusarium species and to quantify DON and NIV toxins in natural malting-barley samples from different producing areas of Argentina. We identified 1180 Fusarium isolates in the 119 samples analyzed, with $51.2 \%$ being F. graminearum, $26.2 \%$ F. poae and $22.6 \%$ other species. We found high concentrations of mycotoxins, at maximum values of $12 \mu \mathrm{g} / \mathrm{g}$ of DON and $7.71 \mu \mathrm{g} / \mathrm{g}$ of NIV. Of the samples, $23 \%$ exhibited DON at an average of $2.36 \mu \mathrm{g} / \mathrm{g}$, with $44 \%$ exceeding the maximum limits (average of $5.24 \mu \mathrm{g} / \mathrm{g}$ ); $29 \%$ contained NIV at an average of $2.36 \mu \mathrm{g} / \mathrm{g} ; 7 \%$ contained both DON and NIV; and $55 \%$ were without DON or NIV. Finally, we report the mycotoxin contamination of the grain samples produced by F. graminearum and F. poae, those being the most frequent Fusarium species present. We identified the main Fusarium species affecting natural malting-barley grains in Argentina and documented the presence of many samples with elevated concentrations of DON and NIV. To our knowledge, the investigation reported here was the first to quantify the contamination by Fusarium and its toxins in natural samples of malting barley in Argentina.
\end{abstract}

Keywords: Fusarium graminearum; Fusarium poae; DON; NIV; barley

Key Contribution: F. graminearum and F. poae are the most abundant Fusarium species in malting barley grains in Argentina. Both DON and NIV toxins were detected in high concentrations. In Argentina; regulations for DON and NIV contents must be established. To our knowledge; the investigation reported here was the first to quantify the contamination by Fusarium and its toxins in natural samples of malting barley in Argentina. 


\section{Introduction}

Barley (Hordeum vulgare L.) —one of the most commercially significant cereals worldwide—is grown in certain regions of Africa and in the highlands of Asia and Latin America, where the grain is usually consumed for human nutrition. In Europe, barley is used for animal feed and in the preparation of alcoholic beverages such as beer and whisky. In Argentina, the grain's main destination is likewise the brewing industry, although the use of barley for animal feed is increasing. The total world production of barley in 2016 was about 150 million tons [1], with the US Department of Agriculture (USDA) estimating that the figure for 2016/2017 will be about 144 million tons. The main barley producers are the European Union (at 59.8 million tons) and Russia (at 17.5 million tons), with Argentina being the tenth worldwide (at 3.2 million tons) (https://www.produccionmundialcebada.com/). According to the Ministry of Agroindustry of Argentina [2], the barley-cultivated area devoted to the brewing industry in 2015/2016 was 1.47 million ha, mainly localized in the central/southern area of the Buenos Aires province $( \pm 90 \%)$, an increase of $33.6 \%$ over the previous growing season.

Barley, along with other cereals, can be contaminated by pathogenic and/or nonpathogenic fungi, and a high level of contamination with fungal species such as Fusarium and/or Penicillium on barley grains has evidenced a significant correlation with a low quality of the resulting malts [3]. A complex of toxigenic and nontoxigenic Fusarium species has been isolated from cereals (wheat, barley, and oat) with symptoms of Fusarium head blight (FHB), a major disease of small-grain cereals that reduces seed quality and yield $[4,5]$. Moreover, certain Fusarium species are potential producers of the trichothecenes deoxynivalenol (DON) and nivalenol (NIV), toxins that are hazardous to the health of both humans and animals through association with certain pathologies-e.g., emesis and feed refusal or loss of appetite, among other negative consequences $[4,6]$.

In Europe, cereal grains are frequently contaminated by Fusarium species such as F. culmorum, F. avenaceum, and F. poae; however, generally, the most common contaminant is F. graminearum [7]. The occurrence of Fusarium species, however, is subject to climatic changes over a period of years and to agricultural practices, such as pesticide applications and nitrogen fertilization [8-10]. In Sweden, F. avenaceum was the species with highest incidence on wheat kernels, followed by F. poae, whereas F. graminearum was the most abundant [9]. In the Umbria region, in central Italy, Beccari et al. [11] found that the predominant Fusarium species on malting-barley grains was F. avenaceum, followed by F. graminearum and F. poae. In a three-year field study, F. avenaceum (in 2012) and F. poae (in 2013)—but never $F$. graminearum - were the most frequently isolated species from barley grains [8].

As with the occurrence of Fusarium species, the mycotoxin content on small-grain cereals has been found to vary. DON levels were seen to have increased after a warm and intense rainfall had occurred during or after anthesis $[12,13]$. Moreover, recently, Li et al. $[14,15]$ demonstrated the presence of a gene that converts DON to DON-3-O-glucoside (nontoxic) and NIV to NIV-O- $\beta$-D-glucoside (nontoxic), thus effecting a detoxification.

Fusarium graminearum and F. poae are typical type-B-trichothecene producers, the former being the greater DON producer and the latter the greater NIV producer [10,16-18]. Certain studies, however, have also cited F. poae as a type-A-trichothecene (HT-2 and T-2) producer [19].

Although neither the number of Fusarium-species isolates nor the quantity of fungal DNA in any specific one necessarily indicates a high concentration of a specific toxin in the resulting cereal samples, and vice versa, various studies have described significant correlations between these variables. F. graminearum and F. culmorum DNAs have been positively associated with the occurrence of DON, F. poae DNAs with NIV, and F. langsethiae DNAs with HT-2 and T-2 in barley samples [20]; F. graminearum with DON in wheat [21,22]; and F. graminearum with DON as well as F. langsethiae with both HT-2 and $\mathrm{T}-2$ in oat [23].

Specific regulations for processed and unprocessed cereal grains with respect to mycotoxin concentrations could vary between regions and/or countries. In the European Union, the European Commission has set maximum limits for unprocessed grains (other than durum wheat, oats, and maize) at $1.25 \mu \mathrm{g} / \mathrm{g}$ (ppm) of DON; however, the maximum limit for NIV has not yet been established, the latter 
being more toxic than the former [24]. By contrast, in Brazil, the Health Surveillance Agency for Brazil (Agência Nacional de Vigilância Sanitària: ANVISA), established a limit of $1.00 \mu \mathrm{g} / \mathrm{g}$ of DON for malted barley [25]. The limits for DON and/or NIV contamination, however, have not yet been established in certain countries of South America, such as Argentina.

Studies on natural samples in different countries—for example, the UK-have indicated that barley grains are contaminated mainly with DON, followed by NIV, although in most instances the levels have been below the established legislative thresholds [20]. In Brazil, 9 out of 50 barley-grain samples were detected with DON in 2013 (ranging from 0.2 to $15.1 \mu \mathrm{g} / \mathrm{g}$ ), while 292 barley samples from a seven-year survey were found to contain a high level of DON in Uruguay (at an average of $2.76 \mu \mathrm{g} / \mathrm{g}$ ) [26,27].

Many studies have demonstrated a decrease in the quality of different cereals as a result of the presence of Fusarium species, even in the absence of contamination from the mycotoxins produced by this fungal genus; with wheat being the most extensively studied cereal at the global and national level $[16,22,28]$. Little is known, however, about the prevalence and diversity of Fusarium species or the accompanying presence of their mycotoxins through field studies on barley $[8,20]$, mainly because the investigations at characterizing the Fusarium graminearum-species complex and its potential to produce toxins have been conducted in vitro [29,30]. Although few such studies have been performed on barley, the presence of Fusarium species on this cereal is known to affect different parameters for malting-e.g., the germination capacity of the grain and the increase in protein and nitrogen content $[20,31,32]$. Many agrarian nations have found an increasing need to understand more completely the impact of the presence of Fusarium on grain yield and quality and the effects of the associated mycotoxins on humans and animals. Moreover, a more thorough knowledge of the presence of Fusarium species and their associated toxins in cereal grains will influence the nature of commercial regulations and modify the thresholds for toxin tolerance on a worldwide basis.

The aim of this work was therefore to study the occurrence of Fusarium species-with particular attention to F. graminearum and F. poae-in malting-barley samples from the principal producing areas of Argentina and to quantify the levels of the toxins DON and NIV contaminating the grains.

\section{Results}

\subsection{Fusarium-Species Identification}

Fusarium graminearum and F. poae were the most frequently isolated Fusarium species among all the samples analyzed. We identified morphologically a total of 1180 Fusarium isolates, where $51.2 \%$ were designated as F. graminearum, $26.2 \%$ as F. poae, and $22.6 \%$ as other species-i.e., $6.5 \%$ as F. incarnatum-F. equiseti species complex, $5.6 \%$ as F. chlamydosporum, $3.6 \%$ as F. oxysporum, $2.5 \%$ as F. acuminatum, $2.2 \%$ as F. proliferatum, $1.4 \%$ as F. tricinctum, $0.6 \%$ as $F$. cerealis, and $0.2 \%$ as F. pseudograminearum.

Fusarium graminearum isolates were obtained in $13.4 \%$ of the total of barley samples analyzed, with each year varying as follows (Table S1; Figure 1): $22.7 \%$ (2012), 37.7\% (2013), and 52.8\% (2014). Conversely, F. poae was isolated in $28.6 \%$ of the total samples, with annual variations at: $68.2 \%(2012)$, $37.7 \%$ (2013) and $75.0 \%$ (2014). In $26.1 \%$ of the total samples, both F. graminearum and F. poae were present, whereas in only 38 out of the 119 samples (31.9\%) was neither F. graminearum nor F. poae isolated (Figure 1). 


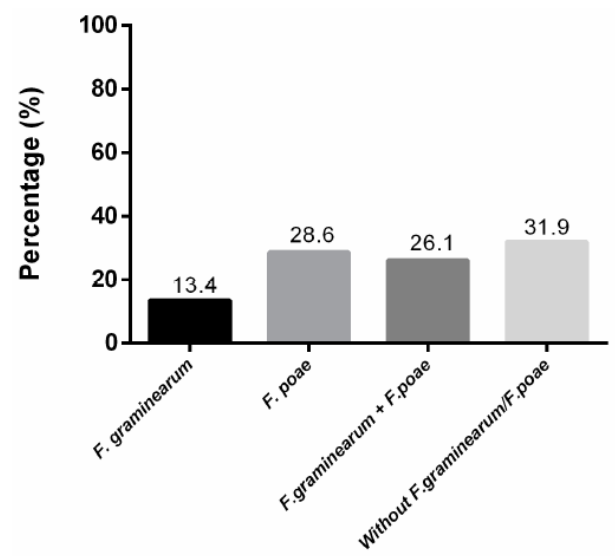

Figure 1. Percentage of samples with or without Fusarium graminearum and/or F. poae. In the figure, the percentage detected among all the isolates is plotted on the ordinate for each of the Fusarium species or their combination indicated on the abscissa. The precise percentages of the different species or combinations are listed above the respective bars.

Among the 24 localities sampled, in only one was neither F. graminearum nor F. poae isolated. In contrast, F. graminearum was isolated from 20 different localities and F. poae from 23 (Table S1).

All the barley genotypes sampled were hosts to F. graminearum and/or F. poae (Table S1).

From all the F. graminearum and F. poae DNA isolates used for molecular characterization, the respective corresponding fragments of $\approx 400 \mathrm{bp}$ and $\approx 220 \mathrm{bp}$ could be amplified. Moreover, from the F. graminearum DNAs, a fragment of 282 bp was amplified that corresponded to the DON genotype and, from the F. poae DNAs, a fragment of 296 bp corresponding to that of NIV.

Although F. graminearum and F. poae were typically respective DON and NIV producers, we could isolate two more Fusarium species capable of producing these toxins, F. pseudograminearum (DON) and F. cerealis (NIV); however, these species were obtained sporadically - F. cerealis from only Samples 14, $22,35,89,90$, and 96 (one contaminated grain per sample) and F. pseudograminearum from only Samples 16 and 23 (one contaminated grain per sample).

\subsection{Trichothecene Screening}

From all the samples analyzed, 16\% (19/119) contained DON (average of $2.6 \mu \mathrm{g} / \mathrm{g}$ ), $44 \%$ of which group exceeded the maximum limits (average of $5.24 \mu \mathrm{g} / \mathrm{g}$ ). A barley sample (Sample 62, Table S1) from Miramar (on the coast of the Buenos Aires province) exhibited the highest level of DON (12 $\mu \mathrm{g} / \mathrm{g}$; Table S1; Figure 2). Twenty-two percent of the samples were contaminated with NIV (average of $2.36 \mu \mathrm{g} / \mathrm{g}$ ), and one sample (Sample 117, Table S1) from Paraná (Entre Ríos province; Figure 2) contained the highest concentration $(7.71 \mu \mathrm{g} / \mathrm{g})$. Seven percent of the samples exhibited DON and NIV in combination, whereas $55 \%$ of the samples were free of both toxins (Table S1; Figure 3). 


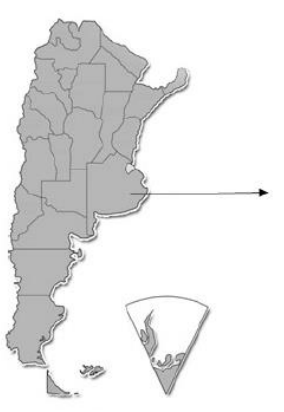

ARGENTINA

F. graminearum and F. poae

F. poce alone

Without F. graminearum/ poae

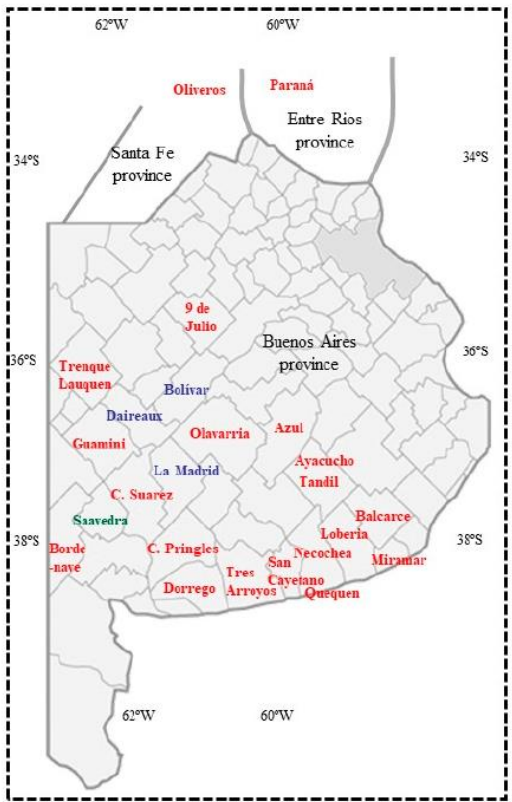

Figure 2. Localities sampled and the presence of Fusarium graminearum and/or F. poae. In the figure, the left panel shows Argentina in its entirety, including the territory in Antartica (pie-shaped inset); the right panel depicts the Buenos Aires province (arrow in left panel). Color key to Fusarium detection in the map of the right panel: red, both F. graminearum and F. poae; blue, F. poae alone; green, without F. graminearum /F. poae

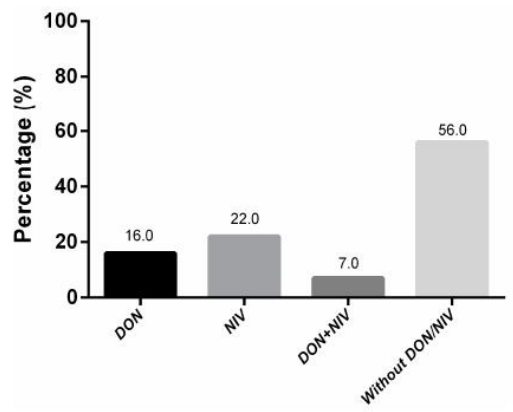

Figure 3. Percentage of samples with or without deoxynivalenol (DON) and/or nivalenol (NIV). In the figure, the percentage of trichothecene detected among all the samples analyzed is plotted on the ordinate of DON alone (black bar), NIV alone (medium-gray bar), both DON and NIV (dark-gray bar), and neither DON nor NIV (light-gray bar) as indicated on the abscissa. The precise percentages of the samples with either or both toxins, or with neither are listed above the respective bars.

A large fraction of the samples (45\%) contained at least one of the two trichothecenes, with 2014 having a significantly higher percentage of samples with toxins than either 2012 or 2013 (Table 1). 
Moreover, except for 2014, where the percentage of each toxin was equal, NIV occurred in a higher percent of the samples than did DON (Table 1).

Table 1. Percentages of samples with mycotoxins per year. Deoxynivalenol (DON); Nivalenol (NIV).

\begin{tabular}{cccc}
\hline Year & $\mathbf{2 0 1 2}$ & $\mathbf{2 0 1 3}$ & $\mathbf{2 0 1 4}$ \\
\hline \% with DON & 9 & 13 & 47 \\
\% with NIV & 27 & 18 & 47 \\
\% without mycotoxins & 64 & 69 & 6 \\
\hline
\end{tabular}

Among the localities sampled, in only three were neither DON nor NIV detected (Oliveros, 9 de Julio, and Daireaux; Table S1; Figure 2), whereas DON was a contaminant in 12 different localities and NIV in 19 (Table S1). DON and/or NIV were found in all the sampled barley genotypes.

\subsection{Statistical Analyses}

The frequencies of F. graminearum and F. poae were 0.85 and 0.92 , respectively. The correlation coefficients between the percent presence of F. graminearum and DON contamination and the percent presence of $F$. poae and NIV contamination were likewise statistically significant at values of $p<0.0001$, $r=0.39$ and $p<0.0001, r=0.50$, respectively. In addition, the correlation coefficient calculated as (total number of F. graminearum + F. poae/the presence of DON $+\mathrm{NIV})$ was statistically significant $(p<0.0001$, $r=0.40)$.

\section{Discussion}

The present work has provided novel data on the occurrence of Fusarium species and their toxins and has determined the two most frequently occurring species in barley, one of the most widely produced small-cereal grains in Argentina.

Although F. graminearum is currently considered the prevalent species in small-cereal grains, such as wheat and barley [16,33]; many studies have demonstrated a high frequency in the occurrence of other Fusarium species, such as F. poae, and have indicated that latter species as being significant and consequential in the ability to produce many mycotoxins whose deleterious effects, in general, have been well documented [34].

Two recent investigations analyzing the various FHB-producing species in malting barley in two different European regions, Italy and the UK, found that the occurrence of those species changed over the different years of the study $[8,20]$. In general, though, the main Fusarium species identified in barley grains were F. avenaceum, F. graminearum, F. poae, and F. tricinctum $[8,20]$. In the present work, we observed that barley grains harvested during 2012-2014 were contaminated mainly with F. graminearum and F. poae; and although the number of isolates of F. graminearum was higher than with F. poae (604 and 309, respectively), the percentage of samples was higher with F. poae than with F. graminearum ( $54.7 \%$ and $39.5 \%$, respectively). That all barley genotypes were host to F. graminearum and/or F. poae is indeed notable. Although the Fusarium-species composition could vary from one year to the next, especially under different climatic conditions and between specific individual barley genotypes, as was subsequently verified by Beccari et al. [8]; the prevalent Fusarium species in the three years under the present study-it involving of the main regions of barley production in Argentina-were F. graminearum and F. poae. Nevertheless, since we did not have the same number of barley samples and/or localities per year, we were unable to validly compare separate years.

In general, warm temperatures and wet conditions were found to favor F. graminearum infection, though temperatures around $25^{\circ} \mathrm{C}$ and dryness did so for F. poae [35]. Table S1 and Figure 2 indicate that the areas sampled in certain instances were in close proximity but others were not. Moreover, the sowing dates had differed; and the general climatic conditions were variable (Figure 4), thus causing the average temperature and humidity during the barley's flowering period to be different among separate 
localities. Apparently, these differing conditions within the sampled areas were insufficient to change the composition of the infective Fusarium species drastically, with F. graminearum and F. poae proving to be the best adapted species for colonization of the principal Argentine barley-growing areas. Nevertheless, a low number of other Fusarium species were found capable of producing trichothecenes, with the patchy occurrence of $F$. pseudograminearum and F. cerealis indicating the need for continuous monitoring.

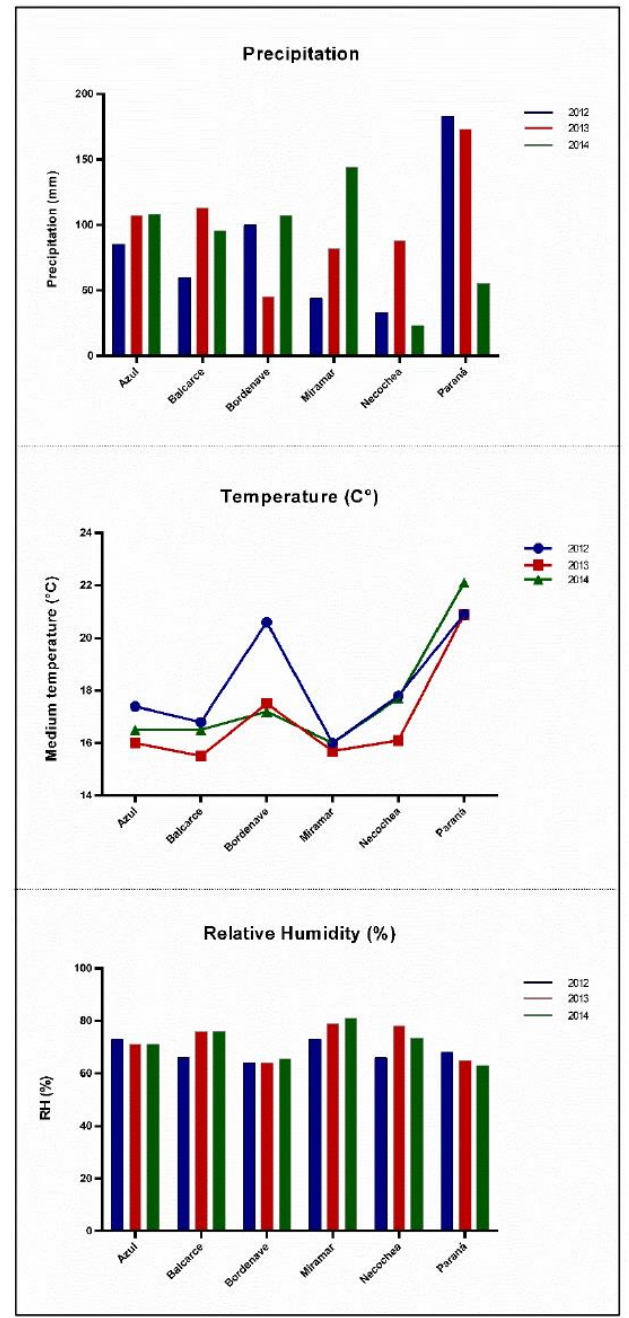

Figure 4. Accumulated precipitation, medium temperature and relative humidity $(\mathrm{RH})$ at barley flowering period (15 October to 15 November) (ordinate). Localities were selected as representatives of geographical areas (abscissa). Color key indicate each sampled year: blue, 2012; red, 2013; and green, 2014. 
The genomes of all the F. graminearum and F. poae screened for the potential production of DON and/or NIV became amplified positively for DON- and/or NIV-related sequences, as had been previously observed for Argentine isolates obtained from barley grains [29,30,34]. Therefore, since we isolated a high frequency of these Fusarium species from many samples, we could anticipate contaminations with these toxins as generated by those species. A correlation analyses accordingly confirmed those expectations. A comparable finding had been observed previously with respect to F. graminearum for DON and F. poae for NIV in wheat [18,22,36], barley [10,36], and oat [23]. Differences in the methodologies, however, can be cited that would be related to a different opportunity for species identification-i.e., DNA identification and/or quantification (e.g., qPCR) vs. conventional fungal isolation (where some species grow too slowly and are thus not recovered), and likewise with respect to the toxin detection and/or quantification methods.

Through the chemical analysis of the presence of DON and/or NIV, we documented that $45 \%$ of the samples contained mycotoxins, in varying concentrations and that NIV was the predominant one in those representative Argentine barley samples. By comparison, a study of Swiss barley revealed that the dominant species was F. graminearum and that DON was the most common mycotoxin, followed by NIV [10]. Nevertheless, although the levels of DNA were higher in F. poae than in F. graminearum in UK barley grains, the contamination with DON prevailed [20]. That European barley grains could be contaminated with another DON-producing species, but to our knowledge not yet isolated in Argentina-e.g., F. culmorum-is certainly relevant. In addition, different environmental conditions (such as climatic parameters) could possibly favor NIV over DON production in Argentine barley-growing areas.

As mentioned above, we were not able to survey the same number of samples per year and/or locality in the study, nevertheless the data in Figure 4 would indicate the influence of climatic conditions on the presence of Fusarium species and toxin contamination, consistent with the results from other studies $[8,20]$. For example, in Paraná (Entre Ríos province), where the agronomic practices were the same throughout the years of the study, the 2013 survey (Samples 65-70, Table S1) contained lower amounts of Fusarium and/or toxins than did the one in 2014 (Samples 116-119, Table S1). Moreover, the year 2014 in Paraná, occasioned higher amounts of NIV and F. poae, in concordance with dry conditions prevailing at the time (Figure 4). In contrast, certain samples presented both F. graminearum and F. poae and high amounts of DON and NIV (Samples 86 and 93, Table S1), thus enabling the possibility that general conditions for DON and/or NIV production were suitable and that different Fusarium species may be competing for the same specific niche so as to thus produce more toxins than if those species were in isolation. Furthermore, certain barley genotypes, but not all those analyzed, in Miramar (2013), contained different amounts of DON and F. graminearum, indicating — as was mentioned by Beccari et al. [8]—different responses between the barley genotype and the presence of Fusarium (Table S1).

In South America, and specifically Brazil and Uruguay, high amounts of DON were detected in malting-barley grains [26,27]. In our study, of the samples contaminated with DON, $12(10 \%)$ contained levels higher than the European limits, and several also had high amounts of NIV. Argentina exports barley grains to different countries both with and without established trichothecene-toxin limits, while part of the production is used nationally in the beer industry, where maximum levels for DON and/or NIV have not yet been established.

The Fusarium biomass along with the Fusarium toxins, such as the trichothecenes DON and NIV, definitely alter the quality of malting $[20,31,32]$, but the main concern regarding the occurrence of Fusarium species is that those same toxins are harmful to humans and animals and are furthermore widespread in all cereal-growing areas of the world. In the work reported here, we identified the main Fusarium species affecting natural malting-barley grains in Argentina and documented the presence of many samples with elevated concentrations of DON and NIV. Moreover, we detected samples containing both toxins. That limits on the concentration of both these toxins be established in barley grains in Argentina as soon as possible is therefore imperative. 
Cereal-grain consumption is continuously increasing worldwide, which process will lead to an enhanced dependence on importation from developing countries. A real potential thus exists for both new and traditional exporters to remedy this imbalance, but the associated problems of food safety and environmental degradation must first be resolved [1]. With respect to food safety, a consideration of good agricultural practices, raw-material sanitation, and the conservation of natural resources-especially those renewable over those nonrenewable-is essential.

The information generated in the present study provides, for the first time, essential data on the Fusarium species and toxins associated with malting-barley grains in Argentina and thus contributes to the future development of sustainable-management strategies, such as plant resistance, sanitation, crop rotations, and the control of toxins in barley production.

\section{Materials and Methods}

\subsection{Barley Samples and Climatic Information}

A total of 119 grain barley samples were harvested and the grains supplied by producers from different areas where this crop had been sown during 2012 (22 samples), 2013 (61 samples), and 2014 (36 samples) (Table S1; Figure 2). The grain samples were reduced from $1 \mathrm{~kg}$ to $200 \mathrm{~g}$ with a grain divider and later reduced to 200 grains ( $10 \mathrm{~g}$, approximately) for Fusarium-species isolation. Of the $200 \mathrm{~g}$ before reduction, $50 \mathrm{~g}$ were removed and maintained at $4{ }^{\circ} \mathrm{C}$ until analysis.

Climatic data (precipitation, temperature, and relative humidity) at the barley flowering period (15 October to 15 November) from representative localities (Azul, Balcarce, Bordenave, Miramar, Necochea and Paraná) were obtained from the National Meteorological Center (Figure 4). Except for 2014 in Bordenave, where precipitation of $182 \mathrm{~mm}$ was observed in a single day (26 October), in general, a normal regimen of precipitations was recorded for the different localities.

\subsection{Fungal Isolation}

The 200 seeds of each sample were surface-disinfected (70\% v/v aqueous EtOH for $2 \mathrm{~min} ; 5 \%(w / v)$ $\mathrm{NaOCl}$ for $2 \mathrm{~min}$ ), rinsed twice in sterilized distilled water, and placed in Petri dishes ( $9 \mathrm{~cm}$ diam) with $2 \%(w / v)$ potato-dextrose agar (PDA) with chloramphenicol at $50 \mu \mathrm{g} / \mathrm{mL}$ and were incubated for approximately five days at $25 \pm 2{ }^{\circ} \mathrm{C}$ in a $12 \mathrm{~h}$ light/dark photoperiod. Potential Fusarium isolates were transferred to 15-mL tubes with PDA and to Petri dishes with carnation-leaf-piece agar, for 7 days under the conditions described above. The isolates were morphologically identified by light microscopy according to the criteria of Leslie and Summerell [37] and were then stored at $4{ }^{\circ} \mathrm{C}$ on Spezieller-Nährstoffarmer agar.

\subsection{Molecular Identification}

Of the isolates identified as F. graminearum and F. poae, $10 \%$ were randomly selected (at least one isolate per sample) for DNA extraction by means of the cetyltrimethylammonium bromide method described by Stenglein and Balatti [38]. The quality of the DNA was verified by electrophoresis in $0.8 \%$ $(w / v)$ agarose gels containing GelRed ${ }^{\mathrm{TM}}$ (Biotium, Hayward, CA, USA) at $80 \mathrm{~V}$ in 1 X Tris-borate-EDTA buffer for $1 \mathrm{~h}$ and visualized under ultraviolet light. The DNA concentration was estimated by fluorometery (Qubit ${ }^{\mathrm{TM}}$ fluorometer, Invitrogen, Buenos Aires, Argentina).

The set of primers used for F. graminearum sensu stricto (later F. graminearum) identification were Fg16F: 5'-CTCCGGATATGTTGCGTCAA-3' and Fg16R: 5'-GGTAGGTATCCGACATGGCAA-3' [39], and for $F$. poae identification primers Fp82-F: 5'-CAAGCAAACAGGCTCTTCACC- $3^{\prime}$ and Fp82-R: 5'-TGTTCCACCTCAGTGACAGGTT-3' [40]. For the NIV and/or DON potential (genotypic characterization), the DNA of $F$. graminearum isolates was evaluated with primers based on the Tri13 gene, Tri13NIVF: 5'-CCAAATCCGAAAACCGCAG-3' and Tri13NIVR: 5'-TTGAAAGCTCCAATGTCGTG-3'; Tri13DONF: 5'-CATCATGAGACTTGTKCRAGTTTGGG- ${ }^{\prime}$ ' and Tri13DONR: 5'-GCTAGATCGATTGTTGCATTGAG-3' [41]. For the corresponding NIV potential, 
the DNA of $F$. poae isolates was evaluated with the primers designed from the Trit gene, nivPf: 5'-TATCCTTGCATGGCAATGCC- ${ }^{\prime}$ and nivPr: 5'-AAATGGCGATACGAGTATTGA-3' [42].

The PCR reactions were performed after Parry and Nicholson [40], Nicholson et al. [39], Chandler et al. [41], and Dinolfo et al. [42]. Each PCR product was examined by gel electrophoresis along with positive and negative controls and a DNA-molecular-weight-standard ladder (100 bp), according to Castañares et al. [29]. DNA from F. poae, F. graminearum sensu stricto, F. asiaticum, F. cortaderiae, F. meridionale, and $F$. austroamericanum were used as controls for the different PCR reactions [29,42].

The results for a single isolate, selected at random, from each Fusarium species identified by morphological methods (F. acuminatum, F. cerealis, F. chlamydosporum, F. equiseti-incarnatum-species complex, F. graminearum, F. oxysporum, F. poae, F. pseudograminearum, F. proliferatum and F. tricinctum) were corroborated by sequencing the region of the elongation factor 1- $\alpha$ in comparison with the National Center for Biotechnology Information (NCBI) database web page [43].

\subsection{Mycotoxin Analysis}

Seeds $(50 \mathrm{~g})$ were finely ground in a blade homogenizer. An aliquot of $12.5 \mathrm{~g}$ of each ground sample was extracted with $50 \mathrm{~mL}$ of acetonitrile:water 86:16 $(v / v)$ and shaken on an orbital shaker for $20 \mathrm{~min}$. The supernatant was filtered through Nr. 101 fast-filter paper. For the clean-up, $8 \mathrm{~mL}$ were expressed through a Myco Sep Trich $+{ }^{\circledR}$ column and $4 \mathrm{~mL}$ of the eluate evaporated to dryness under a flow of nitrogen at $60^{\circ} \mathrm{C}$ on a Turbo Vap L work station (Caliper Life Sciences, Waltham, MA, USA). The resulting extracts were resuspended in $500 \mu \mathrm{L}$ of the mobile phase and passed through a $0.22-\mu \mathrm{m}$ microcellulose filter before injection into the HPLC-UV/Vis system.

The analysis was carried out with a Gilson HPLC-gradient-pump system equipped with a $151 \mathrm{UV} / \mathrm{V}$ is detector. The column was a $250 \times 3-\mathrm{mm}$; $4-\mu \mathrm{m}$ Hydro RP Phenomenex. The mobile phase was acetonitrile:water 20:80 running in the isocratic mode at $1 \mathrm{~mL} / \mathrm{min}$. The DON and NIV peaks were detected at $222 \mathrm{~nm}$ and the quantification was performed using external standards. The validation parameters as well as their acceptance criteria were in accordance with international guidelines [44,45]. The mycotoxins were quantified using an external standard. Linear range was between 0.156 and $2.5 \mu \mathrm{g} / \mathrm{g}$, being $0.156 \mu \mathrm{g} / \mathrm{g}$ limit of quantification. Samples above linear range were diluted and re-analyzed to fit calibration curve values.

We used the criteria of the DON thresholds established by the European Commission for the evaluation of our results.

\subsection{Statistical Analyses}

The frequency of Fusarium species and toxin concentrations were analyzed by Pearson's correlation coefficient with respect to the association between the toxin concentrations and the percentage of F. graminearum and/or F. poae identified in the barley samples. All the statistical analyses were performed with the InfoStat software (version 2016, InfoStat group UNC, Córdoba, Argentina, 2008) [46].

Supplementary Materials: The following are available online at www.mdpi.com/2072-6651/10/2/78/s1. Table S1: Barley genotypes, localities, harvest years, mycotoxin concentration, and percentage of $F$. graminearum (Fg) and F. poae (Fp) isolates obtained per sample. Deoxynivalenol (DON); nivalenol (NIV).

Acknowledgments: This work was supported by FONCYT-SECYT PICT 030/2011 and 213/2015, PIP 0551 CONICET, UNCPBA. Donald F. Haggerty, a retired academic career investigator and native English speaker, edited the final version of the manuscript.

Author Contributions: María Soledad Nogueira, Federico Moreyra, María Virginia Moreno and Sebastia Alberto Stenglein designed the experiments; María Soledad Nogueira, Julieta Decundo, Mauro Martinez, Susana Nelly Dieguez, Federico Moreyra, María Virginia Moreno and Sebastian Alberto Stenglein performed and analysed the experiments; María Soledad Nogueira, Susana Nelly Dieguez and Sebastian Alberto Stenglein, wrote the manuscript.

Conflicts of Interest: The authors declare no conflict of interest. The founding sponsors had no role in the design of the study; in the collection, analyses, or interpretation of data; in the writing of the manuscript, and in the decision to publish the results. 


\section{References}

1. Food and Agriculture Organization of the United Nations. Agricultura Mundial: Hacia los Años 2015/2030. 2017. Available online: http://www.fao.org/docrep/004/y3557s/y3557s08.htm (accessed on 24 February 2017).

2. Ministerio de Agroindustria Argentina. Dirección de Estimaciones Agrícolas y Delegaciones. Estimaciones Agrícolas, Informe Semanal al 30 de Junio de 2016. 2016. Available online: http://www.agroindustria.gob.ar/ sitio/areas/estimaciones/_archivos/estimaciones/160000_2016/000600_Junio/160630_Informe\%20Semanal\% 20Estimaciones\%20-\%20al\%2030-Jun-2016.pdf (accessed on 24 February 2017).

3. Kaur, M.; Bowman, J.P.; Stewart, D.C.; Evans, D.E. The fungal community structure of barley malts from diverse geographical regions correlates with malt quality parameters. Int. J. Food Microbiol. 2015, 215, 71-78. [CrossRef] [PubMed]

4. D'Mello, J.P.F.; Placinta, C.M.; Macdonald, A.M.C. Fusarium mycotoxins: A review of global implications for animal health, welfare and productivity. Anim. Feed Sci. Technol. 1999, 80, 183-205. [CrossRef]

5. Schwarz, P.B. Impact of Fusarium head blight on malting and brewing quality of barley. In Fusarium Head Blight of Wheat and Barley; Leonard, K.J., Bushnell, W.R., Eds.; American Phytopathological Society Press: St. Paul, MN, USA, 2003; pp. 395-419.

6. Desjardins, A.E. Fusarium Mycotoxins Chemistry, Genetics and Biology; American Phytopathological Society Press: St. Paul, MN, USA, 2006.

7. Nicholson, P.; Chandler, E.; Draeger, R.C.; Gosman, N.E.; Dimpson, D.R.; Thomsett, M. Molecular tools to study epidemiology and toxicology of Fusarium head blight of cereals. Eur. J. Plant Pathol. 2003, 109, 691-703. [CrossRef]

8. Beccari, G.; Prodi, A.; Tini, F.; Bonciarelli, U.; Onofri, A.; Oueslati, S.; Limayma, M.; Covarelli, L. Changes in the Fusarium head blight complex of malting barley in a three-year field experiment in Italy. Toxins 2017, 9, 120. [CrossRef] [PubMed]

9. Karlsson, I.; Friberg, H.; Kolseth, A.-K.; Steinberg, C.; Persson, P. Agricultural factors affecting Fusarium communities in wheat kernels. Int. J. Food Microbiol. 2017, 252, 53-60. [CrossRef] [PubMed]

10. Schöneberg, T.; Martinb, C.; Wettsteina, F.; Buchelia, T.D.; Mascherb, F.; Bertossab, M.; Musaa, T.; Kellerc, B.; Vogelgsang, S. Fusarium and mycotoxin spectra in Swiss barley are affected by various cropping techniques. Food Addit. Contam. Part A 2016, 10, 1608-1619. [CrossRef] [PubMed]

11. Beccari, G.; Caproni, L.; Tini, F.; Uhlig, S.; Covarelli, L. Presence of Fusarium species and other toxigenic fungi in malting barley and multi-mycotoxin analysis by liquid chromatography-high-resolution mass spectrometry. J. Agric. Food Chem. 2016, 64, 4390-4399. [CrossRef] [PubMed]

12. Hooker, D.C.; Schaafsma, A.W.; Tamburic-Ilincic, L. Using weather variables pre- and post-heading to predict deoxynivalenol content in winter wheat. Plant Dis. 2002, 86, 611-619. [CrossRef]

13. Roer Hjelkrem, A.-G.; Torp, T.; Brodal, G.; Aamot, H.U.; Strand, E.; Nordskog, B.; Dill-Macky, R.; Edwards, S.G.; Hofgaard, I.S. DON content in oat grains in Norway related to weather conditions at different growth stages. Eur. J. Plant Pathol. 2017. [CrossRef]

14. Li, X.; Michlmayr, H.; Schweiger, W.; Malachova, A.; Shin, S.; Huang, Y.; Dong, Y.; Wiesenberg, G.; McCormick, S.; Lemmens, M.; et al. A barley UDP-glucosyltransferase inactivates nivalenol and provides Fusarium head blight resistance in transgenic wheat. J. Exp. Bot. 2017. [CrossRef] [PubMed]

15. Li, X.; Shin, S.; Heinen, S.; Dill-Macky, R.; Berthiller, F.; Nersesian, N.; Clemente, T.; McCormick, S.; Muehlbauer, G.J. Transgenic wheat expressing a barley UDP-glucosyltransferase detoxifies deoxynivalenol and provides high levels of resistance to Fusarium graminearum. Mol. Plant-Microbe Interact. 2015, 28, 1237-1246. [CrossRef] [PubMed]

16. Osborne, L.E.; Stein, J.M. Epidemiology of Fusarium head blight on small-grain cereals. Int. J. Food Microbiol. 2007, 119, 103-108. [CrossRef] [PubMed]

17. Stenglein, S.A.; Dinolfo, M.I.; Barros, G.; Bongiorno, F.; Chulze, S.; Moreno, M.V. Fusarium poae pathogenicity and mycotoxin accumulation on selected wheat and barley genotypes at a single location in Argentina. Plant Dis. 2014, 98, 1733-1738. [CrossRef]

18. Yli-Mattila, T.; Paavanen-Huhtala, S.; Jestoi, M.; Parikka, P.; Hietaniemi, V.; Gagkaeva, T.; Sarlin, T.; Haikara, A.; Laaksonen, S.; Rizzo, A. Real-time PCR detection and quantification of Fusarium poae, F. graminearum, F. sporotrichioides and F. langsethiae in cereal grains in Finland and Russia. Arch. Phytopathol. Plant Protect. 2008, 41, 243-260. [CrossRef] 
19. Thrane, U.; Adler, A.; Clasen, P.-E.; Galvano, F.; Langseth, W.; Lew, H.; Logrieco, A.; Nielsen, K.F.; Ritieni, A. Diversity in metabolite production by Fusarium langsethiae, Fusarium poae and Fusarium sporotrichioides. Int. J. Food Microbiol. 2004, 95, 257-266. [CrossRef] [PubMed]

20. Nielsen, L.K.; Cookb, D.J.; Edward, S.G.; Ray, R.V. The prevalence and impact of Fusarium head blight pathogens and mycotoxins on malting barley quality in UK. Int. J. Food Microbiol. 2014, 179, 38-49. [CrossRef] [PubMed]

21. Lindblad, M.; Gidlund, A.; Sulyok, M.; Börjesson, T.; Krska, R.; Olsen, M.; Fredlund, E. Deoxynivalenol and other selected Fusarium toxins in Swedish wheat-Occurrence and correlation to specific Fusarium species. Int. J. Food Microbiol. 2013, 167, 284-291. [CrossRef] [PubMed]

22. Martinez, M.; Castañares, E.; Dinolfo, M.I.; Pacheco, W.G.; Moreno, M.V.; Stenglein, S.A. Presencia de Fusarium graminearum en muestras de trigo destinado al consumo humano. Rev. Argent. Microbiol. 2014, 46, 41-44. [CrossRef]

23. Fredlund, E.; Gidlund, A.; Sulyok, M.; Börjesson, T.; Krska, R.; Olsen, M.; Lindblad, M. Deoxynivalenol and other selected Fusarium toxins in Swedish oats-Occurrence and correlation to specific Fusarium species. Int. J. Food Microbiol. 2013, 167, 276-283. [CrossRef] [PubMed]

24. European Commission. Commission Regulation (EC) no. 1881/2006 of 19 December 2006 setting maximum levels for certain contaminants in foodstuff. Off. J. Eur. Union 2006, L364, 5-24.

25. Agência Nacional de Vigilância Sanitària. RDC no. 138. Dispõe sobre limites máximos tolerados (LMT) para micotoxinas. Diário Oficial da Uniāo, 9 de fevreiro de 2017.

26. Pan, D.; Bonsignore, F.; Rivas, F.; Perera, G.; Bettucci, L. Deoxynivalenol in barley samples from Uruguay. Int. J. Food Microbiol. 2007, 114, 149-152. [CrossRef] [PubMed]

27. Piacentini, K.C.; Savi, G.D.; Pereira, M.E.V.; Scussel, V.M. Fungi and the natural occurrence of deoxynivalenol and fumonisins in maltinh barley (Hordeum vulgare L.). Food Chem. 2015, 187, 204-209. [CrossRef] [PubMed]

28. González, H.H.L.; Moltó, G.A.; Pacin, A.; Resnik, S.L.; Zelaya, M.J.; Masana, M.; Martínez, E.J. Trichothecenes and mycoflora in wheat harvested in nine locations in Buenos Aires province, Argentina. Mycopathologia 2008, 165, 105-114. [CrossRef] [PubMed]

29. Castañares, E.; Ramirez Albuquerque, D.; Dinolfo, M.I.; Fernandez Pinto, V.; Patriarca, A.; Stenglein, S.A. Trichothecene genotypes and production profiles of Fusarium graminearum isolates obtained from barley cultivated in Argentina. Int. J. Food Microbiol. 2014, 179, 57-63. [CrossRef] [PubMed]

30. Castañares, E.; Dinolfo, M.I.; Del Ponte, E.M.; Pan, D.; Stenglein, S.A. Species composition and genetic structure of Fusarium graminearum species complex populations affecting the main barley growing regions of South America. Plant Pathol. 2016, 65, 930-939. [CrossRef]

31. Oliveira, P.M.; Mauch, A.; Jacob, F.; Waters, D.M.; Arendt, E.K. Fundamental study on the influence of Fusarium infection on quality and ultrastructure of barley malt. Int. J. Food Microbiol. 2012, 156, 32-43. [CrossRef] [PubMed]

32. Sarlin, T.; Laitila, A.; Pekkarinen, A.; Haikara, A. Effects of three Fusarium species on the quality of barley and malt. Am. Soc. Brew. Chem. 2005, 63, 43-49.

33. Bourdages, J.V.; Marchand, S.; Rioux, S.; Belzile, F.J. Diversity and prevalence of Fusarium species from Quebec barley fields. Can. J. Plant Pathol. 2006, 28, 419-425. [CrossRef]

34. Dinolfo, M.I.; Stenglein, S.A. Fusarium poae and mycotoxins: potential risk for consumers. Bol. Soc. Argent. Bot. 2014, 49, 5-20.

35. Xu, M.N.; Nicholson, P.; Thomset, M.A.; Simpson, D.; Cooke, B.M.; Doohan, F.M.; Brennan, J.; Monaghan, S.; Moretti, A.; Mule, G.; et al. Relationship between the fungal complex causing Fusarium head blight of wheat and environmental conditions. Phytopathology 2008, 98, 69-78. [CrossRef] [PubMed]

36. Nielsen, L.K.; Jensen, J.D.; Nielsen, G.C.; Jensen, J.E.; Spliid, N.H.; Thomsen, I.K.; Justesen, A.F.; Collinge, D.B.; Jørgensen, L.N. Fusarium head blight of cereals in Denmark: species complex and related mycotoxins. Phytopathology 2011, 101, 960-969. [CrossRef] [PubMed]

37. Leslie, J.F.; Summerell, B.A. The Fusarium Laboratory Manual; Blackwell Publishing: Ames, IA, USA, 2006.

38. Stenglein, S.A.; Balatti, P.A. Genetic diversity of Phaeoisariopsis griseola in Argentina as revealed by virulence and molecular markers. Physiol. Mol. Plant Pathol. 2006, 68, 158-167. [CrossRef]

39. Nicholson, P.; Simpson, D.R.; Weston, G.; Rezanoor, H.N.; Lees, A.K.; Parry, D.W.; Joyce, D. Detection and quantification of Fusarium culmorum and Fusarium graminearum in cereals using PCR assays. Physiol. Mol. Plant Pathol. 1998, 53, 17-37. [CrossRef] 
Publicaciones derivadas

40. Parry, D.W.; Nicholson, P. Development of a PCR assay to detect Fusarium poae in wheat. Plant Pathol. 1996, 45, 383-391. [CrossRef]

41. Chandler, E.; Simpson, D.; Thomsett, M.; Nicholson, P. Development of a PCR assays to Tri7 and Tri13 trichothecene biosynthetic genes, and characterisation of chemotypes of Fusarium graminearum, Fusarium culmorum and Fusarium cerealis. Physiol. Mol. Plant Pathol. 2003, 62, 355-367. [CrossRef]

42. Dinolfo, M.I.; Barros, G.G.; Stenglein, S.A. Development of a PCR assay to detect the potential production of nivalenol in Fusarium poae. FEMS Microbiol. Lett. 2012, 332, 99-104. [CrossRef] [PubMed]

43. Ward, T.J.; Clear, R.M.; Rooney, A.P.; O’Donnell, K.; Gaba, D.; Patrick, S.; Starkey, D.E.; Gilbert, J.; Geiser, D.M.; Nowicki, T.W. An adaptive evolutionary shift in Fusarium head blight pathogen populations is driving the rapid spread of more toxigenic Fusarium graminearum in North America. Fungal Genet. Biol. 2008, 45, 473-484. [CrossRef] [PubMed]

44. U.S. Department of Health and Human Services, FDA, CDER, CVM. Guidance for Industry, Bioanalytical Method Validation; U.S. Food and Drug Administration: Maryland, MD, USA, 2001.

45. European Commission Decision. Implementing Council Directive Concerning the performance of analytical methods and the interpretation of the results. Off. J. Eur. Commun. 2012, L221, 23-33.

46. Di Rienzo, J.A.; Casanoves, F.; Balzarini, M.; Gonzalez, L.; Cuadroda, M.; Robledo, C. InfoStat Versión 2016; Grupo InfoStat, FCA, Universidad Nacional de Córdoba: Córdoba, Argentina, 2008. 
ANEXO 


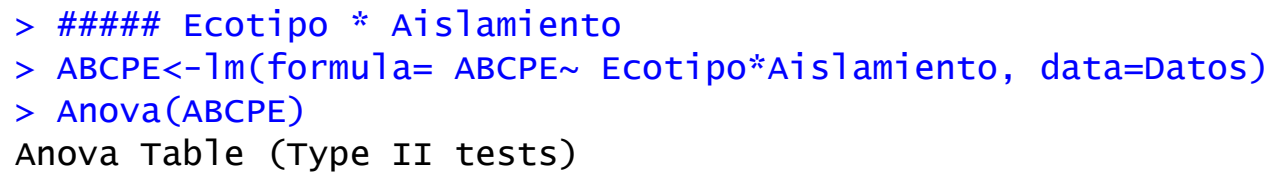

Response: $A B C P E$

$\begin{array}{lrrrr} & \text { Sum Sq } & \text { Df } F \text { value } & \text { Pr }(>F) \\ \text { Ecotipo } & 180.11 & 6 & 21.8602<2.2 \mathrm{e}-16 * * * \\ \text { Aislamiento } & 1046.51 & 9 & 84.6793<2.2 \mathrm{e}-16 * * * \\ \text { Ecotipo:Aislamiento } & 548.74 & 54 & 7.4004<2.2 \mathrm{e}-16 * * * \\ \text { Residuals } & 2729.85 & 1988 & \end{array}$

Signif. codes: 0 “***’ 0.001 “**, 0.01 “*’ 0.05 ‘’ 0.1 “' 1 $>$ cld(1smeans (ABCPE, Ecotipo*Aislamiento), type = "response") Ecotipo Aislamiento 1smean SE df lower.CL upper.CL

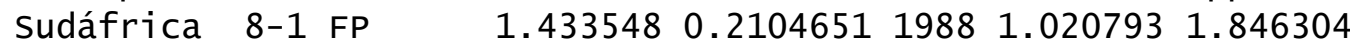
$\begin{array}{lllllllllll}\text { Irán } & 8-1 & \text { FP } & & 1.499655 & 0.2176015 & 1988 & 1.072904 & 1.926406\end{array}$ $\begin{array}{lllllllllllllll}\mathrm{Bd} & 9-5 & \mathrm{FP} & 1.756552 & 0.2176015 & 1988 & 1.329801 & 2.183303\end{array}$ $\begin{array}{llllllllll}\text { Israel } & 8-1 & \text { FP } & 2.042258 & 0.2104651 & 1988 & 1.629503 & 2.455013\end{array}$ $\begin{array}{lllllllllllllllllll}\text { Uruguay } & 8-1 & \text { FP } & 2.188667 & 0.2139441 & 1988 & 1.769089 & 2.608245\end{array}$ $\begin{array}{llllllllllllllll} & \text { uruguay } & 25-5 & \text { FP } & 2.193667 & 0.2139441 & 1988 & 1.774089 & 2.613245\end{array}$ $\begin{array}{llllllllll}\text { Irán } & 9-5 & \text { FP } & 2.395667 & 0.2139441 & 1988 & 1.976089 & 2.815245\end{array}$ $\begin{array}{llllllllll}\text { Afganistán 8-1 FP } & 2.649615 & 0.2298128 & 1988 & 2.198916 & 3.100315\end{array}$ $\begin{array}{llllllllllll}\text { Bd } & 106-35 & \text { FPS } & 2.692667 & 0.2139441 & 1988 & 2.273089 & 3.112245\end{array}$ $\begin{array}{lllllllll}\text { Irán } & 102-43 & \text { FG } & 2.698966 & 0.2176015 & 1988 & 2.272215 & 3.125716\end{array}$ $\begin{array}{llllllllllll}\text { Bd } \quad 105-41 & \text { FC } & 2.752500 & 0.2214531 & 1988 & 2.318195 & 3.186805\end{array}$ $\begin{array}{llllllllllllll}\text { Bd } & 8-1 & \text { FP } & 2.793571 & 0.2214531 & 1988 & 2.359267 & 3.227876\end{array}$ $\begin{array}{llllllllll}\text { Afganistán 9-5 FP } & 2.821923 & 0.2298128 & 1988 & 2.371224 & 3.272622\end{array}$ $\begin{array}{llllllllllllll}\text { Pakistán } & 8-1 & \text { FP } & 3.024000 & 0.2139441 & 1988 & 2.604422 & 3.443578\end{array}$ $\begin{array}{llllllllllll}\text { Sudáfrica } & 112-10 & \text { FC } & 3.134000 & 0.2139441 & 1988 & 2.714422 & 3.553578\end{array}$ $\begin{array}{lllllllllllllll}\text { Irán } & 25-5 & \text { FP } & 3.136897 & 0.2176015 & 1988 & 2.710146 & 3.563647\end{array}$ $\begin{array}{lllllllllll}\text { Sudáfrica } & 9-5 & \text { FP } & 3.200333 & 0.2139441 & 1988 & 2.780755 & 3.619911\end{array}$ $\begin{array}{llllllllll}\text { Sudáfrica } & 25-5 & \text { FP } & 3.243333 & 0.2139441 & 1988 & 2.823755 & 3.662911\end{array}$ Pakistán $\quad 105-41$ FC $\quad 3.252857 \quad 0.2214531 \quad 1988 \quad 2.818553 \quad 3.687162$ $\begin{array}{lllllllllll}\text { Irán } & 106-35 & \text { FPS } & 3.253667 & 0.2139441 & 1988 & 2.834089 & 3.673245\end{array}$ $\begin{array}{llllllllll}\text { Uruguay } & 9-5 & \text { FP } & 3.275000 & 0.2139441 & 1988 & 2.855422 & 3.694578\end{array}$ $\begin{array}{llllllllll}\text { Bd } & 25-5 & \mathrm{FP} & 3.325000 & 0.2139441 & 1988 & 2.905422 & 3.744578\end{array}$ $\begin{array}{lllllllllll}\text { Irán } & 16-2 & \text { FPS } & 3.331000 & 0.2139441 & 1988 & 2.911422 & 3.750578\end{array}$ Bd 102-43 FG Afganistán 25-5 FP Uruguay $34-15$ FG Israel 9-5 FP Pakistán 34-15 FG Sudáfrica 105-41 FC Uruguay 106-35 FPS Irán 112-10 FC Uruguay $112-10 \mathrm{FC}$ Afganistán 105-41 FC Pakistán 25-5 FP $\begin{array}{llllll}3.346667 & 0.2139441 & 1988 & 2.927089 & 3.766245\end{array}$ $\begin{array}{llllll}3.384286 & 0.2214531 & 1988 & 2.949981 & 3.818590\end{array}$ $\begin{array}{llllll}3.462000 & 0.2139441 & 1988 & 3.042422 & 3.881578\end{array}$ $3.551290 \quad 0.2104651 \quad 1988 \quad 3.138535 \quad 3.964046$ $3.552333 \quad 0.2139441 \quad 1988 \quad 3.132755 \quad 3.971911$ $3.595000 \quad 0.2071504 \quad 1988 \quad 3.188745 \quad 4.001255$ $\begin{array}{llllll}3.728667 & 0.2139441 & 1988 & 3.309089 & 4.148245\end{array}$ $\begin{array}{llllll}3.780968 & 0.2104651 & 1988 & 3.368213 & 4.193723\end{array}$ $\begin{array}{llllll}3.845667 & 0.2139441 & 1988 & 3.426089 & 4.265245\end{array}$ $\begin{array}{llllll}3.859259 & 0.2255168 & 1988 & 3.416985 & 4.301533\end{array}$ Israel 106-35 FPS $\begin{array}{llllll}3.898571 & 0.2214531 & 1988 & 3.464267 & 4.332876\end{array}$ $\begin{array}{llllll}3.972333 & 0.2139441 & 1988 & 3.552755 & 4.391911\end{array}$ 


\begin{tabular}{|c|c|c|c|c|c|c|}
\hline & & & & & & \\
\hline & 5-41 FC & & & & & \\
\hline Sudáfrica & 106-35 FPS & 333 & & 988 & & \\
\hline $\mathrm{Bd}$ & $34-15$ FG & 07333 & & & & \\
\hline srael & $102-43$ FG & & & & & \\
\hline akistán & $112-10$ FC & & & 988 & & \\
\hline & $16-2$ FPS & & & 1988 & & \\
\hline nistán & $112-10 \mathrm{FC}$ & & & & & \\
\hline & $102-43$ FG & & & & & \\
\hline & $107-18$ FG & & & & & \\
\hline & $-41 F C$ & & & & & \\
\hline & 41 FC & & & & & \\
\hline & 5 FG & & & & & \\
\hline Erica & $-43 \mathrm{FG}$ & & & & & \\
\hline Irán & 5 FG & & & & & 562 \\
\hline & $112-10 \mathrm{FC}$ & & & & & \\
\hline istán & $102-43 \mathrm{FG}$ & & & & & \\
\hline$d$ & $112-10$ FC & & & 1988 & & 682 \\
\hline & 106-35 FPS & & & & & \\
\hline & $16-2$ FPS & & & & & 207 \\
\hline stán & 16-2 FPS & & & & & 776 \\
\hline & $16-2$ FPS & & & & & \\
\hline & $-18 \quad F G$ & & & & & \\
\hline nistán & $34-15$ FG & & & & & \\
\hline frica & $16-2$ FPS & & & & & 134 \\
\hline istán & $102-43 \mathrm{FG}$ & & & & & \\
\hline Sudáfrica & $107-18$ FG & 4. & & 1988 & & 5245 \\
\hline Paki & $9-5$ FP & 4. & & 1988 & & 1923 \\
\hline & $34-15$ FG & & & 1988 & & 5578 \\
\hline & $107-18$ FG & & & & & 7888 \\
\hline & $107-18$ FG & & & & & \\
\hline & $16-2$ FPS & & & & & \\
\hline & $107-18$ FG & & & & & 9207 \\
\hline & 106-35 FPS & & & & & \\
\hline Irán & $107-18$ FG & 5.482333 & 0.2139441 & 1988 & 5.062755 & 5.90191 \\
\hline
\end{tabular}


Alumna: Lic. María Soledad Nogueira

Director: Dr. Sebastián Alberto Stenglein

Co-directora: Dra. María Virginia Moreno

Asesora académica: Dra. Cecilia Mónaco 